\title{
ALGAE REEFS AND OOLITES OF THE GREEN RIVER FORMATION
}

\author{
By W. H. Bradley
}

\section{INTRODUCTION}

Reefs or beds and isolated nodules of fresh-water algal limestone are abundant in several parts of the Green River formation of Wyoming, Colorado, and Utah. Locally they constitute more than 8 per cent of the basal member of the formation and occur in single reefs or groups of reefs as much as 5.5 meters (18 feet) thick. (See pl. 29, A.) Oolitic limestone and algal pebble beds are also plentiful but thinner.

These algae reefs and oolitic beds are interesting not only because they make up an appreciable part of the formation but also because they indicate that the parts of the lakes in which they and the associated beds were formed were shallow and clear except in times of storm, that the lakes had sheltered bays in which an emergent vegetation flourished, and that the streams feeding the lakes brought in a copious supply of dissolved calcium salts.

It is also worthy of passing note that the algae reefs of the Green River formation, although formed in inland lakes during the middle part of the Eocene epoch, are remarkably similar to those found in the Miocene lake beds of the Rhine Valley in Germany. The same species of alga has been the chief agent in forming the reefs in each of these two widely separated localities, and, so far as the writer is aware, deposits with a comparable internal structure are elsewhere unknown.

\section{STRATIGRAPHY AND ECOLOGY}

The algae reefs of the Green River formation are most plentiful in shore phases of the formation, as between White and Yampa Rivers in Moffat and Rio Blanco Counties, Colo., and in the northeastward extension of the Bridger Basin in Sweetwater County, Wyo. In both these areas the formation consists of silty shale, sandstone, ostracode and oolitic limestone, and shell marl. Oil shale is practically absent, and beds of shale containing even a small quantity of organic matter are not abundant. In these areas bedlike algae reefs are irregularly distributed through the entire thickness of the formation, but elsewhere in the Green River formation algae reefs are confined almost wholly to the basal member, whose lithology is similar to that of the shore phases. The left-hand column of the section shown in Plate 28 illustrates the kinds of rocks with which algae reefs are habitually associated. This lithology, moreover, is fairly typical of the basal member of the Green River formation in Wyoming as well as in Colorado and Utah, although the proportions of the different kinds of rock vary considerably from place to place.

So far as the writer has observed algae reefs are nowhere closely associated with beds of even moderately rich oil shale but only with sandy and limy shale beds whose oil yields range from a trace to about 5 gallons a ton. This is not surprising, however, because the conditions on the lake bottom where beds of richer oil shale formed were utterly different from those where algae reefs formed. The formation of rich oil shale requires stagnation of water and active putrefaction of vast quantities of organic matter, the products of which would quickly precipitate the lime in solution and also foul the bottom so that it would be unfavorable for most benthonic plants except saprophytes. These conditions are clearly inimical to the formation of algae reefs and explain their absence from the oil-shale zones and also from much of the remainder of the Green River formation, which consists predominantly of shale that may be conveniently termed lowgrade oil shale, defined as somewhat limy shale that is finely laminated and that contains enough organic matter to yield on distillation less than 15 gallons of oil to the short ton. In most places beds of richer oil shale are interbedded at rather wide intervals with the low-grade oil shale. The middle and right-hand columns of Plate 28 show the typical lithology of the Green River formation above the basal member.

Locally, as in the vicinity of Parachute Creek, Colo., that part of the section between the basal member and the lowest oil-shale zone consists of hard limy or silty shale and contains a few thin algae reefs. In a few places that part of the formation above the uppermost oil-shale zone also contains thin algae reefs, as in the vicinity of Indian Canyon and near the Duchesne-Uinta county line in Utah. (See pl. 31.)

Each of the two great Eocene lakes, one in Wyoming and the other in Colorado and Utah, in which the basal member of the Green River formation accumulated may be pictured as a very broad sheet of water flooding a large, nearly level fluviatile plain, the 
top of the Wasatch formation. This plain was built up of clay, silt, and sand brought down by streams from the surrounding mountains, and as the alluvial material is predominantly clay the basinward slopes must have been very gentle.

The beds of clay and stream-channel sandstone of the Wasatch formation in the greater part of each basin are comparable to the youngest flood-plain deposits in Sacramento Valley, Calif., between Butte City and Montezuma Hills, which, according to Bryan ${ }^{1}$ consist chiefly of blue clay and silt with deposits of coarser sand and gravel that were laid down in more or less braided stream channels. The gradient of Sacramento River through this area is a little less than 19 centimeters to the kilometer ( 1 foot to the mile). If this gradient is assumed for the basin floors over which the earliest Green River lakes spread and if it is also assumed that the water was not more than 3 or 4 meters (10 or 15 feet) deep near the shores where the algae reefs formed, then the deepest parts of the lakes near the centers of the basins may have been as much as 15 or 18 meters (50 or 60 feet) deep. But other things being equal, lacustrine sedimentation must soon have lessened this relief on the lake floor so that while the greater part of the basal member was being formed the lake bottoms were nearly level. On the other hand, the earliest lakes may have started as small ponds and backwaters along the stream courses in the alluvial plain and expanded very gradually, filling their basins and leveling up the plain as they grew, until finally they spread over the entire plain from mountain flank to mountain flank.

In these two great shallow lakes algae flourished and built bedlike reefs that expanded broadly over the smooth lake floors. Fish, mollusks, crustaceans, and aquatic insect larvae were also plentiful in the lakes, and turtles (Baptemys sp. and Echmetemys sp.), crocodiles, birds, and small camels, as well as myriads of winged insects, frequented the lake shores. Along some shores there were marginal swamps which persisted for a considerable time and whose former positions are revealed now by thin coal beds.

But these lakes, despite their enormous area and slight depth, must have been fairly stable water bodies, for some of the thicker algae reefs required, according to the writer's estimate, at least 355 years to form. During that time only slight changes in water level, rate and manner of circulation, and rate of sedimentation could have occurred. Such changes would register in the growth layers of the reef. A considerably longer period of static equilibrium is indicated by the composite reef near the divide between Douglas and Salt Creeks, Colo., which is 5.5 meters (18 feet) thick.

1 Bryan, Kirk, Geology and ground-water resources of Sacramento Valley, Calif.: U. S. Geol. Survey Water-Supply Paper 495, pp. 7, 10, 39-43, 1923.
The periodic stability indicated by the algae reefs suggests that the lakes had outlets during at least part of the time, for lakes in inclosed basins are extremely sensitive to climatic changes, and their levels fluctuate perceptibly even "when ordinary weather observations, taken at a limited number of localities in their neighborhood, fail to indicate analogous changes in atmospheric conditions." 2 It is possible that between such periods of stability in the early stages of the Green River lakes they did not overflow. The prevalence of sun-cracked bedding planes and mud curls in some parts of the basal member supports this hypothesis. Yet complete desiccation was probably not frequent, if indeed such an extreme condition was even approached. In the basal member no salt crystallized out in the bottom mud. These lakes, however, may have been comparable in relative permanence, depth, and content of dissolved salts to Goose Lake, Oreg. Goose Lake lies in a region whose average annual rainfall is about 51 centimeters ( 20 inches). It contains about 1,000 parts per million of dissolved salts, rarely overflows, and although very shallow has never been known to dry up. ${ }^{3}$

It is plain that in later stages of the Green River lakes they had no outlets, for they became progressively more saline until finally large quantities of glauberite crystallized out in the bottom mud. During the saline stages many of the principal oil-shale beds formed. The deposits of these later stages are clearly different from those of the basal member and reflect marked changes in the aspect and constitution of the lakes as they grew older.

\section{FIELD WORK AND ACKNOWLEDGMENTS}

This paper describes a collection of algae reefs and oolites made during the field seasons of 1923, 1924, and 1925. During 1923 the writer was assisted by C. H. Dane, of the United States Geological Survey; in 1924 by C. E. Erdmann, also of the Geological Survey; and in 1925 by R. D. Ohrenschall. These men the writer wishes to thank for their cooperation in the field and their interest in the problems that have since arisen.

In the autumn of 1925 the writer visited Canandaigua Lake, N. Y., to collect recent algal pebbles, and in July, 1926, he visited Green Lake, N. Y., to examine and collect specimens of the algae reefs now forming there.

\section{MODERN ALGAE REEFS IN GREEN LAKE, N. Y. STRUCTURE}

An examination of the structure of algae reefs now forming in Green Lake, N. Y., assists greatly to in-

2 Russell, I. C., Lakes of North America, p. 71, 1895

${ }^{8}$ Waring, G. A., Geology and water resources of a portion of south-central Oregon: U. S. Geol. Survey Water-Supply Paper 220, pp. 12, 38, 1908. 


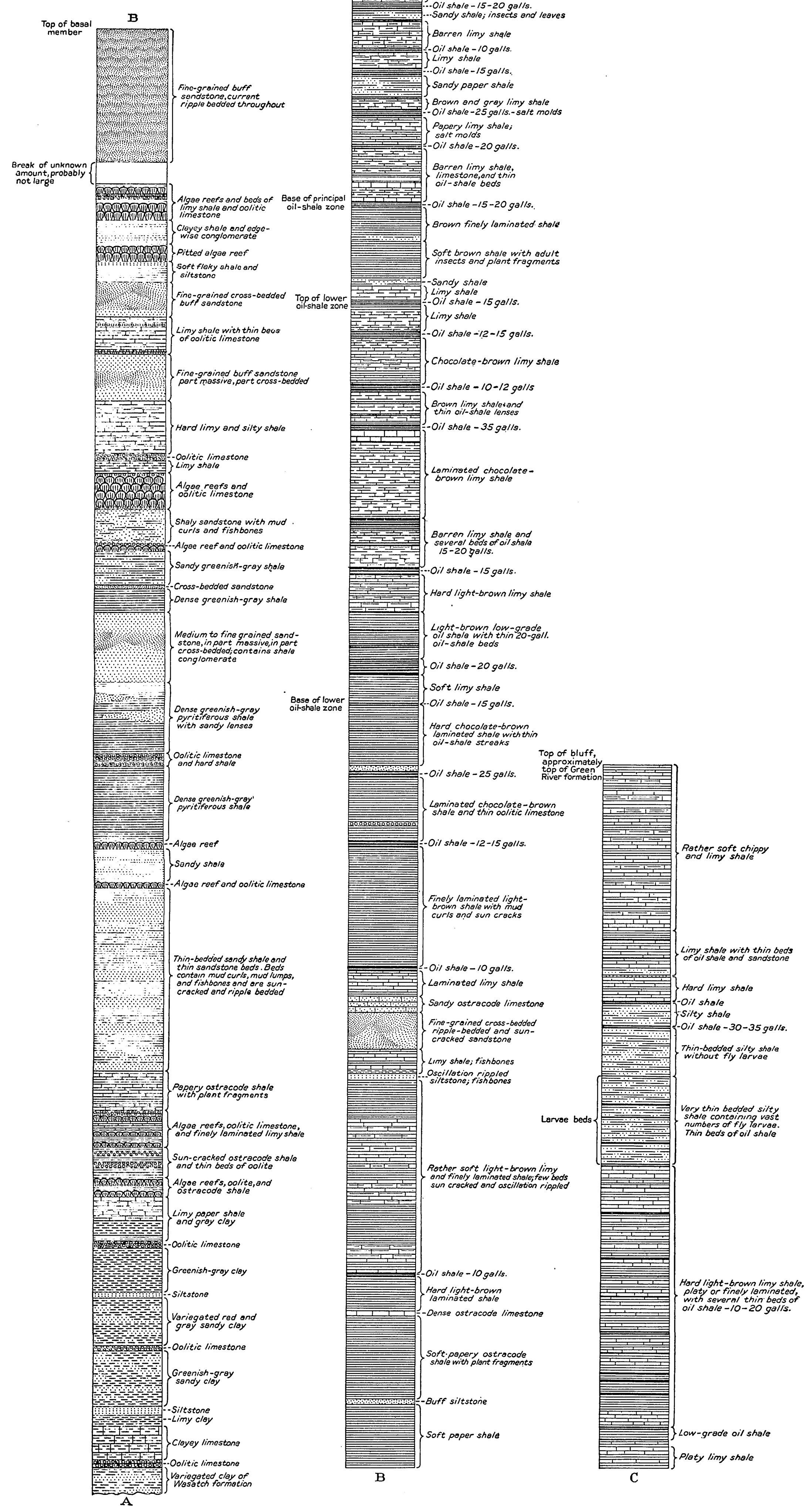




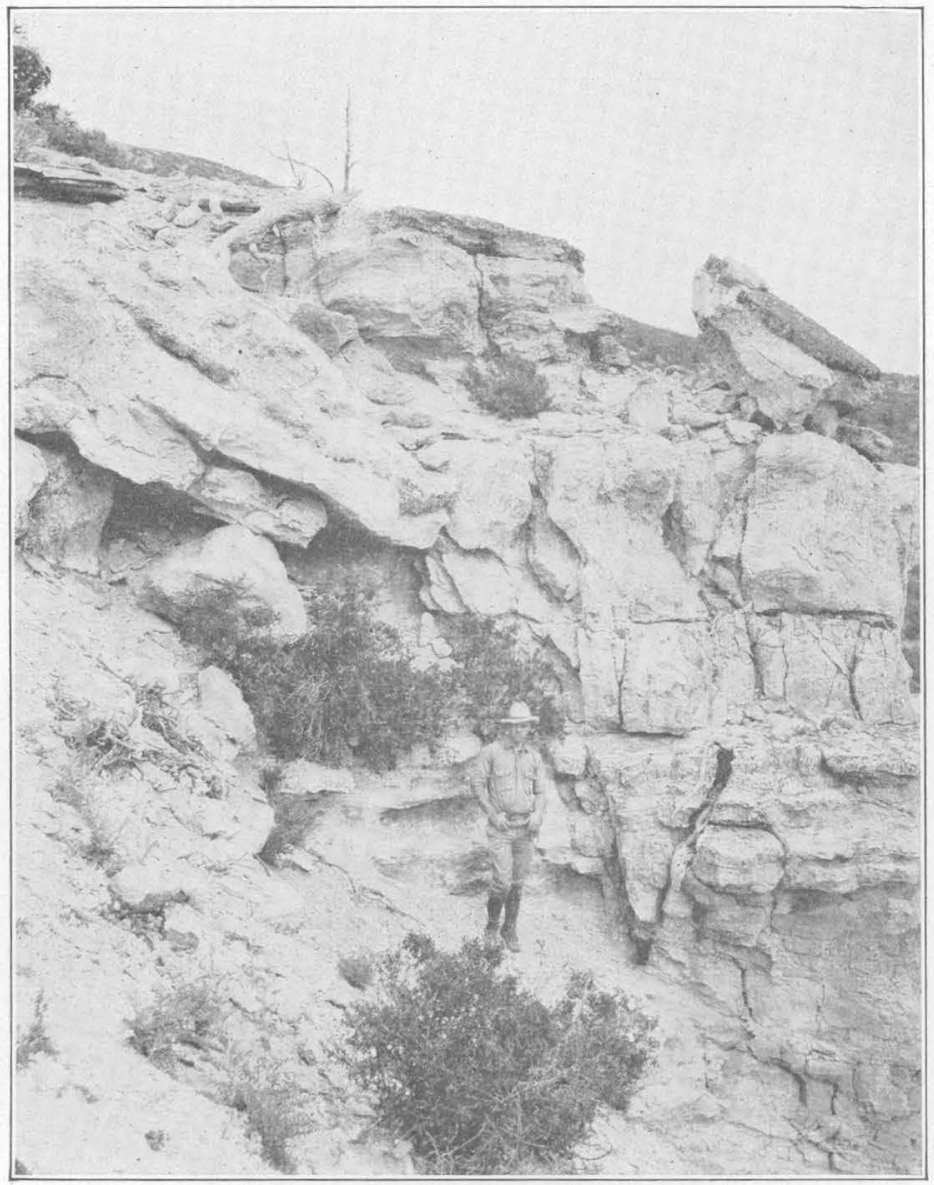

A. GROUP OF SUPERIMPOSED ALGAE REEFS IN THE UPPER PART OF THE BASAL MEMBER OF THE GREEN RIVER FORMATION NEAR THE DIVIDE BETWEEN WEST DOUGLAS AND EAST SALT CREEKS, COLO.

The man's feet are at the base of the lowest reef, which truncates the shaly sandstone beds below; his shoulders are level with a thin reef that has unusual pencillated structure. The thin dark-colored bed at the top of the unit consists of algal pebfeet) thick

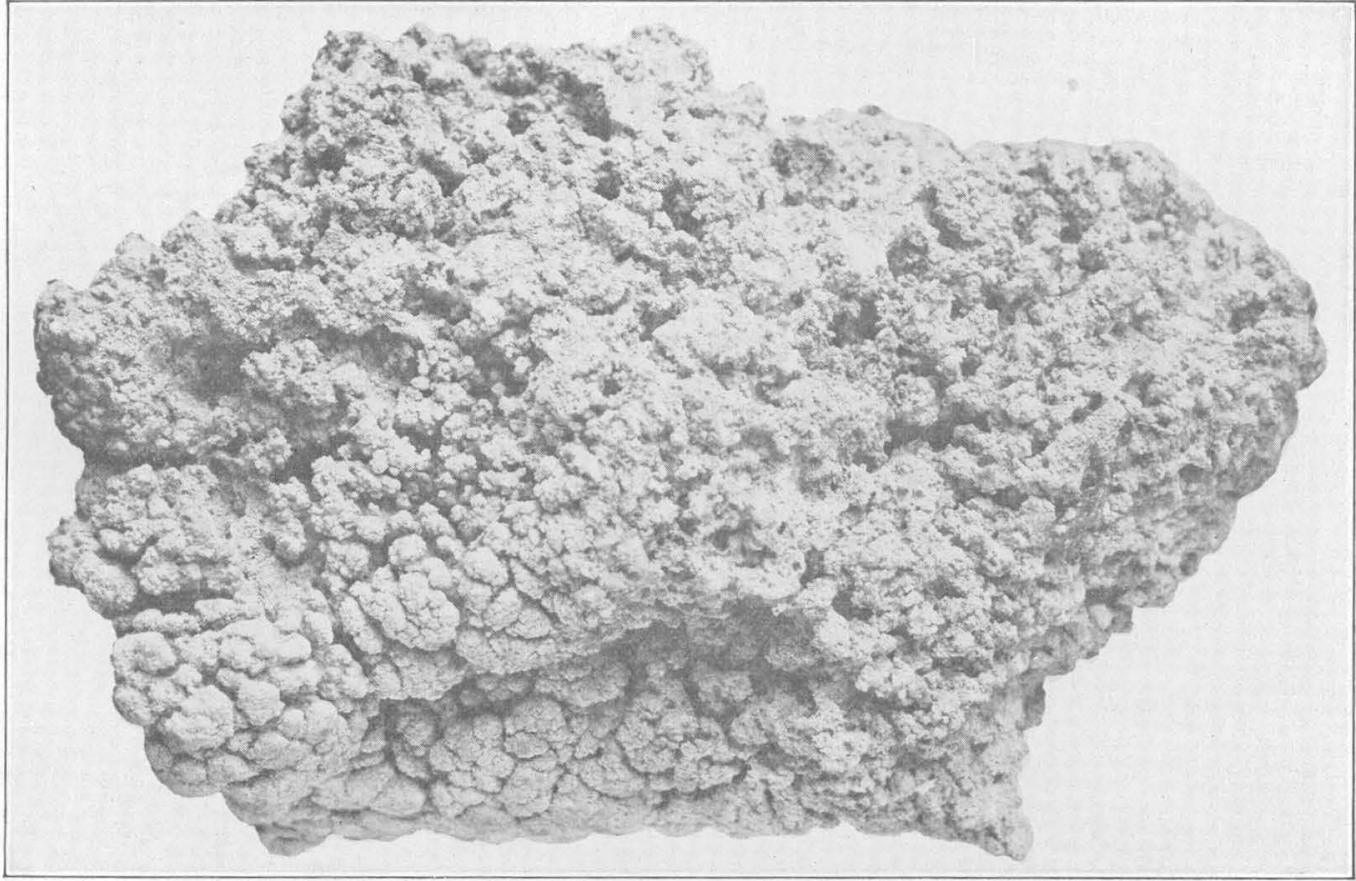

B. RECENT ALGAL DEPOSIT FROM GREEN LAKE, N. Y. The upper rough part is grayish green, owing to the dense felt of algae, whose tips were only thinly incrusted with lime. The
lower, smoother part, which was buried in a soft limy mud, is yellowish gray, dense, and without living algae. Natural size 


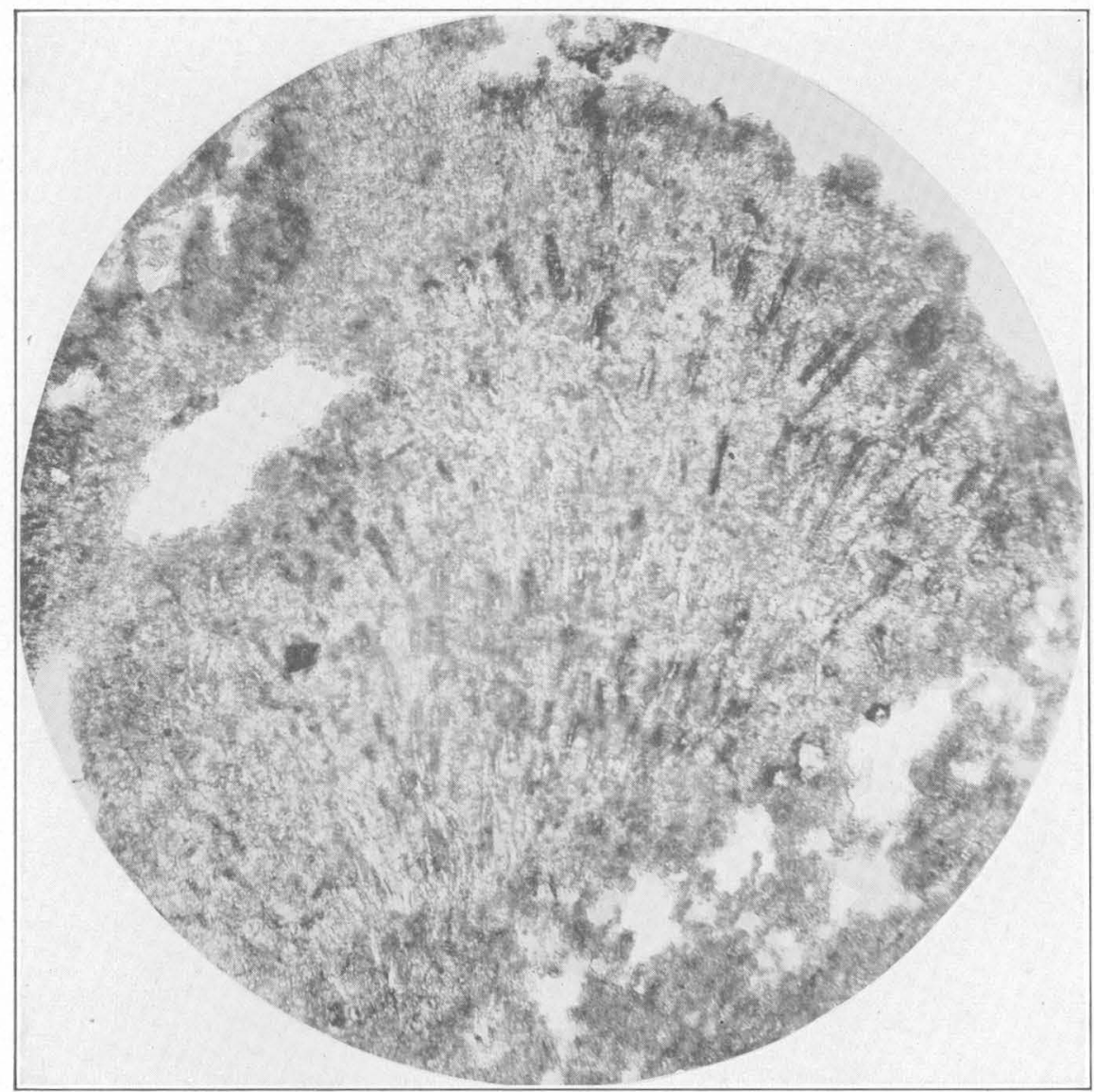

A. THIN SECTION OF A RECENT ALGAE REEF FROM GREEN LAKE, N. Y.

Showing the tubular molds of the thalli of a filamentous alga, Microcoleus paludosa (Kützing) Gommont, was impregnated for sectioning. Enlarged 75 diameters

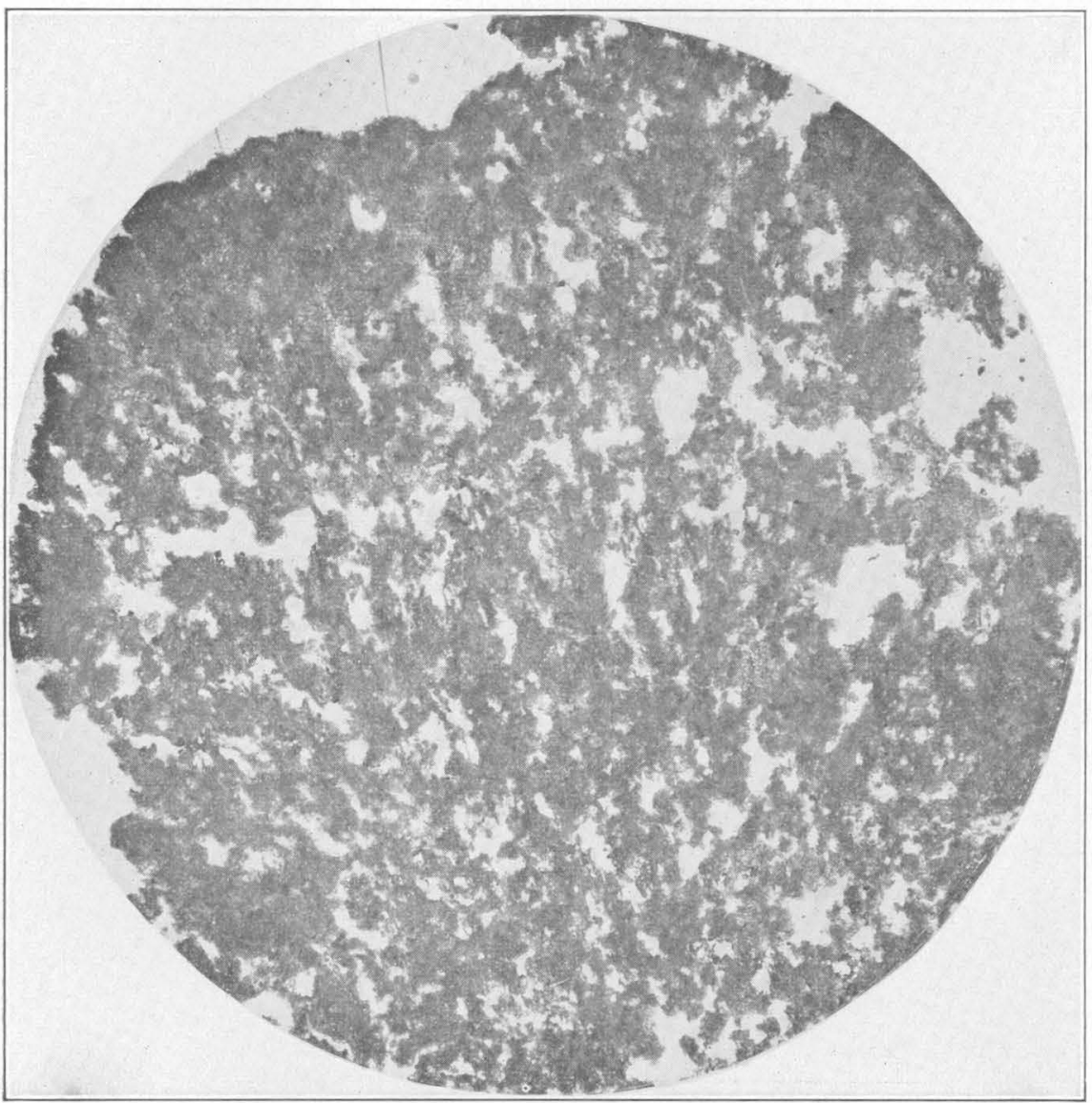

B. THIN SECTION OF A RECENT ALGAE REEF FROM GREEN LAKE, N. Y.

Showing the typical spongy structure of the microcrystalline calcite produced by a felt of fresh-water algae. This also shows a portion of the recrystallized and more dense surface layer in the upper left
quadrant. Enlarged 30 diameters 
U. S. GEOLOGICAL SURVEY

PROFESSIONAL PAPER 154 PLATE 31

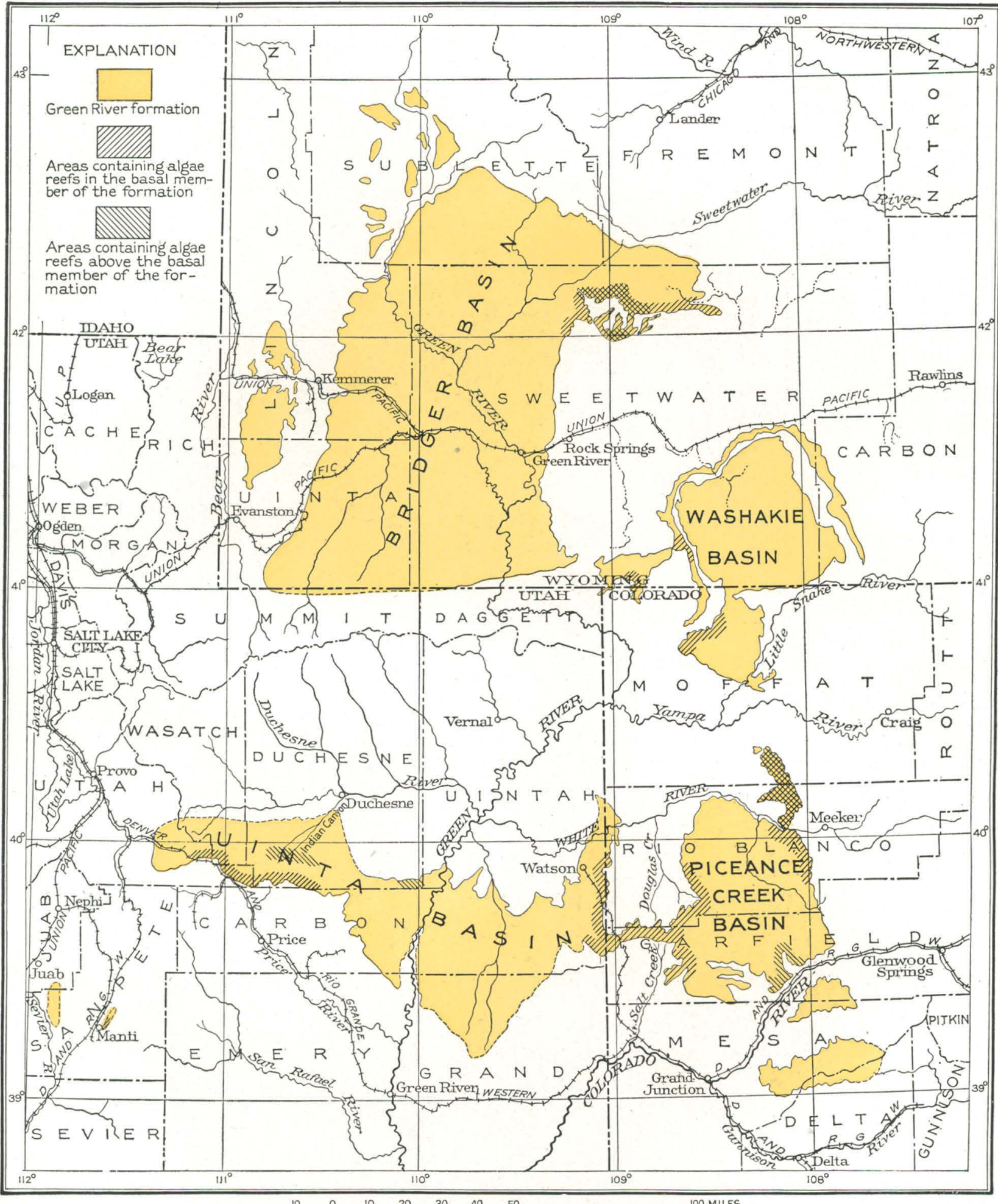

\begin{tabular}{llllllll}
10 & 0 & 10 & 20 & 30 & 40 & 50 & 100 \\
\hline
\end{tabular}

GEOLOGIC MAP SHOWING THE DISTRIBUTION OF THE ALGAE REEFS IN THE GREEN RIVER FORMATION

Geology compiled from published reports of Winchester, Schultz, Veatch, Sears, Ball, and Bradley and unpublished field data of E. E. Smith and E. G. 
terpret the spongy structure of many fossil reefs. In Green Lake algae form not only fringing reefs but also thick incrustations on the trunks and branches of trees that have fallen into the water. All these deposits are exceedingly porous or spongy and consist of more or less closely intergrown arborescent masses that are richly nodose. They resemble arborescent native copper but are more profusely branched. (See pl. $29, B$.) An outer layer ranging in thickness from about 0.25 to 3.0 centimeters is soft and crumbly, but below that the deposit is as hard as ordinary porous limestone.

Apparently the form of the limy deposit is determined by the growth habit of the algae, for if the calcium carbonate in the softer outer layer is dissolved in dilute acetic acid there remains a very dense felt of algae which retains the original dimensions and intricate form. Close to the surface the calcium carbonate, in the form of minute granules 3 to 6 microns in diameter, partly fills the interstices between the algae filaments and unicells and thus makes a very imperfect cast of the interstices or, stated differently, a mold of the plants. But because the algae are so densely entangled the resulting molds are those of groups or small felts of the plants rather than of individual plants. Only rarely in such complex assemblages of algae are the individual filaments or unicells so widely separated that recognizable molds of them are formed. (See pl. $30, A$.)

A little below the surface of these deposits the calcium carbonate is somewhat coarser grained. The crystal growth thus indicated diminishes a little the spaces originally occupied by algae and also distorts whatever molds of individual plants may have formed. This diminution of pore space, however, is slight, and the resulting deposit after the algae have decayed and completely disappeared is exceedingly porous and exhibits the typical spongy structure. Some of it shows clearly the dominant radial lineaments of the algae. (See pl. 30, B.) Although this spongy deposit shows neither cell structure nor any molds of algae, it is highly distinctive and owing to its unusual external form is not readily confused with limestone of any other kind.

The spongy structure of these recent algae reefs is practically identical with that found in many of the fossil reefs from the Green River formation. (See pl. $34, A$.) However, few fossil deposits are so porous, because some or even all the interstices have subsequently been filled with calcite or silica. These secondary fillings are, nevertheless, clearly distinguishable from the original deposit.

Those parts of the algal deposits in Green Lake, N. Y., which have been buried in a finely granular gray or white limy silt have been somewhat modified. The intricately arborescent and finely nodose or granular protuberances have become smoother, more rounded, and more compact. (See pl. 29, B.) Thin sections of these parts show that the interstices have been filled with calcite, so that an outer layer 0.1 to about 1 centimeter thick is dense and somewhat banded concentrically. Along these bands many of the calcite crystals are radially elongated. The change is apparently inorganic and confined to those parts that are buried. Perhaps ammonia from the decomposing algae hastened the precipitation and recrystallization of these buried parts.

\section{ORGANISMS}

The dense felt of algae obtained by dissolving out the calcium carbonate from the material collected in Green Lake, N. Y., consists of an assemblage of bluegreen algae together with a few green algae. The most abundant forms are Microcoleus paludosa (Kützing) Gommont, Palmella miniata Leiblein, Chroococcus helveticus Nägeli, and Lyngbya subtitis W. West; and of these Microcoleus, by reason of its greater bulk, predominates, yet the minute cells and colonies of Palmella are vastly more numerous. Palmella cells are probably the unidentified "rounded or oval, very small cells" that C.A. Davis referred to in his notes on the lime deposits of Green and Round Lakes, N. Y., published in Walcott's description of some pre-Cambrian algal deposits. ${ }^{4}$ Lyngbya and Palmella are most plentiful close to the surface of the algal felt, where they are associated with the algae listed below in the order of their estimated abundance:

Hapalosiphon aureus West and West, locally plentiful. Gloeocapsa sp.

Radiofilum sp.

Rivularia sp.

Dicothrix orsiniana (Kützing) Bornet and Flahault.

Diatoms belonging to several genera are scattered through the mass of other algae.

The calcium carbonate precipitated by these algae was tested to see whether it was aragonite or calcite. The two most generally used chemical tests with cobalt nitrate and ferrous sulphate were applied but gave inconclusive results. Pieces tested in cobalt nitrate became pinkish lavender, whereas crystals of aragonite used as a check turned lavender but with a perceptibly bluer tone. Calcite crystals also immersed for a check remained colorless. In ferrous sulphate pieces of the material caused a yellow precipitate, which, however, had at first a dull greenish cast. Johnston, Merwin, and Williamson ${ }^{5}$ have pointed out the uncertainty of these tests, especially if the material is finely divided or in the form of aggregated fine particles.

C. S. Ross, of the Geological Survey, kindly examined some of the material for the writer and found

4 Walcott, C. D., Pre-Cambrian Algonkian algal flora: Smithsonian Misc. Coll, vol. 64, p. 88,1914 .

s Johnston, John, Merwin, H. E., and Williamson, E. D., The several forms of calcium carbonate: Am. Jour. Sci., 4 th ser., vol. 41 , pp. $476-478,1916$. 
that all the crystals large enough to be determined optically were uniaxial and therefore calcite.

There remains the possibility that some of the finer grains are or were originally aragonite. That they are now aragonite appears unlikely, for Johnston, Merwin, and Williamson ${ }^{6}$ have demonstrated that in aqueous solutions aragonite is unstable in the presence of finely divided calcite. These grains are very small, 3 to 6 microns in diameter, and are interlocked with the minute calcite grains. Moreover, these deposits formed under water, where they remained for a considerable time. It also seems improbable that these finest grains were originally aragonite, for the small calcite crystals with which they are associated in the surface layer of the deposit are not idiomorphic, as they probably would be if recrystallized from aragonite. Moreover, older parts of the deposit obviously furnished calcite nuclei, a fact which in itself makes the original deposition of aragonite very improbable, as pointed out by Johnston, Merwin, and Williamson. ${ }^{7}$

Hassack $^{8}$ and Chambers $^{9}$ have demonstrated that the function of algae in the precipation of calcium carbonate is merely to remove by their photosynthesis the carbon dioxide from the system. Under the conditions which occur in Green Lake, N. Y., calcite is the stable product. Perhaps in a lake that contained considerable sulphate in solution aragonite containing some calcium sulphate in solid solution would be the stable form. ${ }^{10}$

\section{GENERAL FORM OF THE FOSSIL ALGAE REEFS}

The algae reefs of the Green River formation have the form of irregular lenses or beds rather than of ridges or mounds, and they differ considerably in thickness from place to place. Little is known about their extent and proportions, partly because the exposures are inadequate but chiefly because the urgency of other field work has always left insufficient time to map them. Plate 31 shows their distribution in a general way. The shaded portions represent areas in which the writer has observed reefs together with a narrow border zone that represents their probable minimum extent beneath cover and along the strike of the beds from the observed outcrops. Their actual extent is almost certainly considerably greater than that shown. Those portions of the outcrops along White River from the vicinity of Meeker to Douglas Creek, Colo., along the east side of the Bridger Basin in Wyoming from the Union Pacific Railroad north to

\footnotetext{
6 Idem, p. 501.

Idem, p. 483

8 Hassack, Carl, Über das Verhaltnis von Pflanzen zu Bicarbonaten ünd uber Kalkincrustation: Untersuchungen aus dem Bot. Inst. zu Tübingen, vol. 2, pp. $467-473,1888$

- Chambers, C. O., The relation of algae to dissolved oxygen and carbon dioxide with special reference to carbonates: Missouri Bot. Garden Ann. Rept., vol. 23, pp. 188-204, 1912

10 Johnston, John, Merwin, H. E., and Williamson, E. D., op. cit., p. 482.
}

the area indicated on the map by shading, from White River to Green River in Utah, and between Little Snake and Yampa Rivers, together with several localities in the adjoining country to the northwest, have been examined and found barren of algae reefs. The remainder of the unshaded portions represent either unexamined outcrops or areas where the formation, though near the surface, is not exposed.

The shape and size of modern algal deposits appears to be governed largely by the lake-shore profile. The modern algal tufas of Pyramid Lake, Nev., like most of the Pleistocene tufas of the ancient Lake Lahontan, are true fringing reefs, because the shore profiles are steep and the maximum depth at which they could form is not far from shore. Similarly in Green Lake, $\mathrm{N}$. Y., the shore of which has an exceedingly steep profile, the algal reefs are narrow and fringing. In lakes with more gently sloping shores, such as Ore Lake, Mich., ${ }^{11}$ the algal deposits are more bedlike but thickest near shore and progressively thinner outward where the water deepens. Baumann ${ }^{12}$ shows that the beds of algal pebbles now forming in Unter See, Germany, below the outlet of the Lake of Constance are rather thin but extend over very large areas in the shallow bays ( 1 to 4 meters deep), which are free from strong currents. Some of those deposits are nearly equidimensional, but more of them are two to three times longer than broad.

Apparently, therefore, algal deposits must of necessity be bedlike in shallow lakes which are free from strong currents and whose bottoms have a gentle slope and but slight relief. Over such bottoms they may expand freely, their size and shape being limited only by a decrease in the lime supply or changes in environment that would be unfavorable to the propagation of the algae-for example, a considerable increase in either the turbidity or the depth of the water or long-continued stagnation and fouling of the water.

The few reefs of the Green River formation that have been traced in the field serve to illustrate their probable variety of form. Some of these, 2 meters ( 6 feet) or more thick, cover only a small area and end abruptly; others cover many square miles and apparently thin progressively toward the borders. Most of the reefs are of this bedlike type. On a few there are portions that rise above the general level of the reef as much as 1.3 meters ( 4 feet). This relief evidently existed until reef building ceased, because the bedding of the overlying shale conforms to the marked irregularities of the reef surface and laps up tangentially against the steepest sides of these high parts.

The under surfaces of reefs conform to the substrata, which, unless they are algal, are practically flat. An exception to this rule, however, is found in a

It Pollock, J. B., Michigan Acad. Sci. Twentieth Ann. Rept., p. 249, 1918.

"Baumann, Eugen, Die Vegetation des Untersees (Bodensee): Archiv Hydro. biologie u. Planktonkunde, Suppl. Bd. 1, pp. 26-31, pl. 11, 1911. 
reef in Sweetwater County, Wyo., which apparently filled a rather broad and shallow depression in the lake bottom. Its upper surface is essentially level.

Small isolated algal heads or groups of them are scattered in the beds below many reefs. These are precursors of the major reefs, are not connected with them, and are not to be confused with rootlike processes that extend downward from reefs into the underlying rocks, such as those in the Buntsandstein described by Kalkowsky. ${ }^{13}$

Each reef consists of an aggregate of more or less dome-shaped or puffball-shaped masses of algal limestone. These will be referred to as heads. They may be entirely separate one from another, or they may be merely botryoidal convexities or arches in a continuous layer. (See pls. $40, A ; 44, A ; 45, A$.) Moreover, each head may be simple and consist of superimposed smooth, concentric, or slightly eccentric layers, or it may be compound and consist of few to many smaller heads which in nearly all reefs are fused together. (See pl. 44, B.) Such small heads, particularly if formed by a single species of alga, may represent the growth of individual colonies. But if the deposit was formed by a complex assemblage of algae then they represent merely areas of more rapid growth, and generally, though not invariably, these are somewhat arborescent, are less uniform in size, and have a less regular distribution in the larger head. (See pl. $43, A$.)

\section{ORGANISMS AND STRUCTURE UNICELLULAR ALGAE}

Many algae reefs of the Green River formation are built up of successive crescentic groups of small, closely packed spherical or ellipsoidal shells of calcite separated by thinner layers of microcrystalline calcite. These delicate shells range in diameter from 103 to 122 microns and consist of a mosaic of comparatively large platelike crystals of clear calcite. In the silicified reefs they are filled with small anhedral grains of secondary quartz, but in the unsilicified reefs they are empty. Where they are closely appressed many are caved in on one side, greatly distorted, or completely crushed.

Each delicate limy shell is the mold of a unicellular alga formed by the precipitation of $\mathrm{CaCO}_{3}$ on the surface of the living plant through its photosynthesis, a process by which the plant abstracts $\mathrm{CO}_{2}$ from the water and its dissolved bicarbonates and thus, by diminishing the concentration of the carbonate ion in the system, reduces the solubility of the normal carbonate to the point of precipitation.

These algae are almost identical with Chlorellopsis coloniata Reis. Except for a slight difference in the size of the cells the original description of the genotype will serve for the algae of the Green River formation.

13 Kalkowsky, Ernst, Oolith und Stromatolith in norddeutschen Buntsandstein Deutsche geol. Gesell. Zeitschr., vol. 60, p. 112, 1908.

\section{Genus CHLORELLOPSIS Reis}

Chlorellopsis coloniata Reis

Plate $32, A$ and $B$

Chlorellopsis coloniata Reis, Kalkalgen and Seesinterkalk aus dem rheinpfalzischen Tertiar: Geognostische Jahresh., vol. 36 , pp. $107-109$, pl. 3, figs. 1, 2, pl. 4, figs. 3-6. Miocene lake beds of the Rhine graben, Germany, 1923.

A free translation of Reis's description is as follows:

Body perfectly spherical, consisting of a shell of very fine interlocking grains of calcite, which is preserved only if filled with precipitated microcrystalline calcium carbonate that enters it through an accidental rupture in the cell wall (or a break formed by swarm spore liberation?). Otherwise the spherical cavity is later filled with coarser-grained clear calcite similar to the rock matrix. In all occurrences the spheres have approximately the same diameter: the few odd-sized ones range in diameter from 110 to 140 microns. * * * The spheres occur mostly in colonies, more rarely in a series or row, commonly without definite arrangement in little low heaps, often, however, also in structures with steep and even overhanging sides; they might therefore have been held together in a jelly. They are found, nevertheless, in niches, little pits, and depressions in various kinds of limy growths * * * but never in the detrital grains around them; they often also occur in protected places, as the insides of snail shells. They are always separated from the substratum and from each other, but the spacing is not regular.

The spheres occur not only in groups by themselves that are separated by thin limy layers by also sporadically associated with all the other kinds of algae in the Miocene Tertiary marls of the Rhine lake basin, although more rarely in beds containing solely marine animal remains or in the fine-grained limestones intercalated with them.

Living spherical algae of comparable size are Halosphaera (marine), Eremosphaera (100 to 145 microns), Chlorella, which lives in marine lower organisms and of whose species Chlorella infusionum is of the same size as our fossil. The marine Palmophyllum should be related to Chlorella. It forms a rounded and lobate thallus of unicells held together in a jelly which is attached to calcareous algae, etc.

The spherical shells in the reefs of the Green River formation range in diameter from 103 to 122 microns and so are only slightly smaller than these and surely not so different as to determine another species. Their mode of preservation is slightly different, and they have not yet been found in snail shells, but the identity of the Green River alga with Chlorellopsis coloniata Reis seems beyond question.

It was perhaps somewhat misleading to compare Chlorellopsis coloniata with the living Chlorella infusionum, because of the confusion that exists in the nomenclature of the living algae. Beyerinck, ${ }^{14}$ who without apparent reason proposed Chlorella to supersede 7oochlorella Brandt, described Chlorella infusionum as free living, never in families, with small cells ( 1 to 4 microns) which are often flattened and rarely short cylinders. Furthermore, Beyerinck ${ }^{15}$ regarded this alga as identical with Chlorococcum infusionum

1t Beyerinck, M. W., Culturversuche mit Zoochlorellen, Lichenengonidien und anderen neideren Algen: Bot. Zeitung, vol. 48, p. 726, 1890.

is Idem, p. 758. 
(Schrank) Mengehini as described by Rabenhorst, ${ }^{16}$ in spite of the fact that his and Rabenhorst's descriptions are utterly different. However, Chlorococcum infusionum (Schrank) Mengehini as described by Rabenhorst ${ }^{17}$ agrees rather closely with the fossil alga, and hence it seems to the writer unfortunate that the fossil should have been likened to Chlorella infusionum Beyerinck rather than to Chlorococcum infusionum (Schrank) Mengehini. Consequently the name Chlorellopsis Reis is also unfortunate, for, although it does not necessarily imply consanguinity with the living plant, it nevertheless links the fossil to some extent with a doubtful genus which the species coloniata resembles considerably less than it does Chlorococcum.

For comparison a translation of Rabenhorst's description of Chlorococcum infusionum ${ }^{18}$ is given below.

Aquatic, green, mucous; cells perfectly globular, size exceedingly variable; integument hyaline, distinct, thick, concentrically laminated; cytoplasm suffused with chlorophyll, homogeneous, and dark olive color, forming a great number of gonidia.

Diameter of cells, all the way up to [usque] 0.0045 inch (114.3 microns).

Habit, everywhere in stagnant water, either affixed to submerged bodies or free floating.

Collins ${ }^{19}$ says of the habit of this alga that its cells are loosely united into light-green gelatinous masses that are attached to submerged objects but are easily scattered.

Although there is a strong resemblance in form and habit between the fossil algae and Chlorococcum infusionum (Schrank) Mengehini; their mode of reproduction and color are unknown, and therefore their systematic position must remain uncertain.

\section{FILAMENTOUS ALGAE}

Indisputable calcite molds of filamentous algae have not been found in the reefs of the Green River formation, although in a small partly silicified area of an algae reef from the "Manti beds," probably a part of the Green River formation, there is a network of slender branching white lines, which are circular in cross section and whose algal origin can be demonstrated. They are embedded in a translucent matrix and can be seen to best advantage in a polished specimen. (See pl. $33, C$.) A thin section of this area showed that the white lines consist of an interlocking aggregate of irregular microscopic granules of chalcedonic quartz and that the matrix is microcrystalline or almost cryptocrystalline calcite.

Although these fossils show cellular structure in places and very probably represent more than one

${ }^{16}$ Rabenhorst, Ludvico, Florae Europae algarum aqae dulcis et submarinae, vol. 3 , p. 57, Leipzig, 1868.

17 Idem, p. 57

${ }^{18}$ Idem, p. 57.

${ }^{10}$ Collins, F. S., The green algae of North America: Tufts College Studies, vol. 2, No. 3, p. 144, 1909. genus, they can not be positively identified and are therefore provisionally referred to the indefinite form genus Confervites Brongniart.

\section{Genus CONFERVITES Brongniart \\ Confervites mantiensis Bradley, n. sp. \\ Plate $33, A$}

Filaments consisting of a single series of cells, straight or slightly curved, tips rounded or bluntly tapered, 90 to 138 microns in diameter and 0.5 to 1.25 millimeters long. Most are simple, but some are sparsely branched at rather wide angles, resembling many Confervae.

Several of these quartz filaments contain centrally placed, short chains of excellently preserved cells of an alga resembling Nostoc. These cells range from 39.4 to 67 microns in diameter and 27.5 to 50 microns in length and apparently represent more than one species. None of them are branched, and only one contains a cell that seems clearly to be a heterocyst. The uniform zone of silica between the chains of cells and the microcrystalline calcite apparently represents a gelatinous sheath around which the calcite was precipitated. Presumably the silica replaced the organic structure subsequent to the formation of the calcite mold and apprently so late that only fragments of the plants remained. (See pl. 33,A.) There are also fragments of filaments. which have short cylindrical cells and suggest some of the Oscillatoriaceae.

Associated with Confervites mantiensis are many very well preserved though small coprolites. (See p. 33, $B$.) They are cylindrical, have irregularly or squarely truncated or rounded ends, are of various lengths, and range in diameter from 38 to 77 microns but are mostly about 60 microns. Some are compact and dense, but many of them consist of a close mesh of ragged, irregular or dendroid opaque particles resembling organic tissue that has been very strongly macerated. A few consist of more or less loosely aggregated black subangular to spherical particles about 1.5 to 2 microns in diameter.

\section{SPONGY STRUCTURE}

Several algae reefs of the Green River formation contain zones of radially arranged thin bifurcating lines of clear calcite, more coarsely grained than the matrix, which may be casts of filamentous algae. (See-pl. $34, B$.) However, most of the reefs or parts of them, which show these zones in places, consist of spongy or porous masses of microcrystalline calcite which, aside from forming crescentic or mammillate layers, show no systematic structure. (See pl. 34, A.) Deposits of this kind seem to be exactly comparable to that formed within the dense felt of algae in the reefs now growing in Green Lake, N. Y., and in other recent fresh-water algae reefs as described by Clarke, ${ }^{20}$

${ }^{20}$ Clarke, J. M., The water biscuit of Squaw Island, Canandaigua Lake, N. Y.: New York State Mus. Bull. 39, pp. 195-198, 1900. 


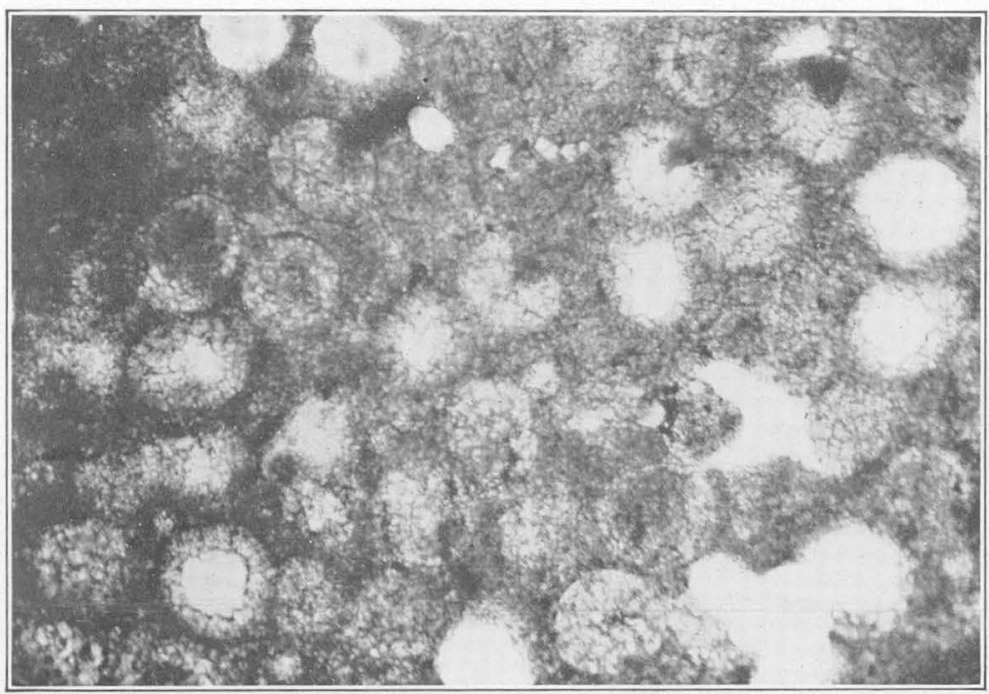

A. PHOTOMICROGRAPH OF A THIV SECTION SHOWING IN DETAIL THE INDIVIDUAL CELLS OF CHLORELLOPSIS COLONIATA REIS

The walls of each hollow sphere consist of a mosaic of moderately coarse grained calcite crystals. The dark matrix is microcrystalline calcite. Enlarged 100 diameters

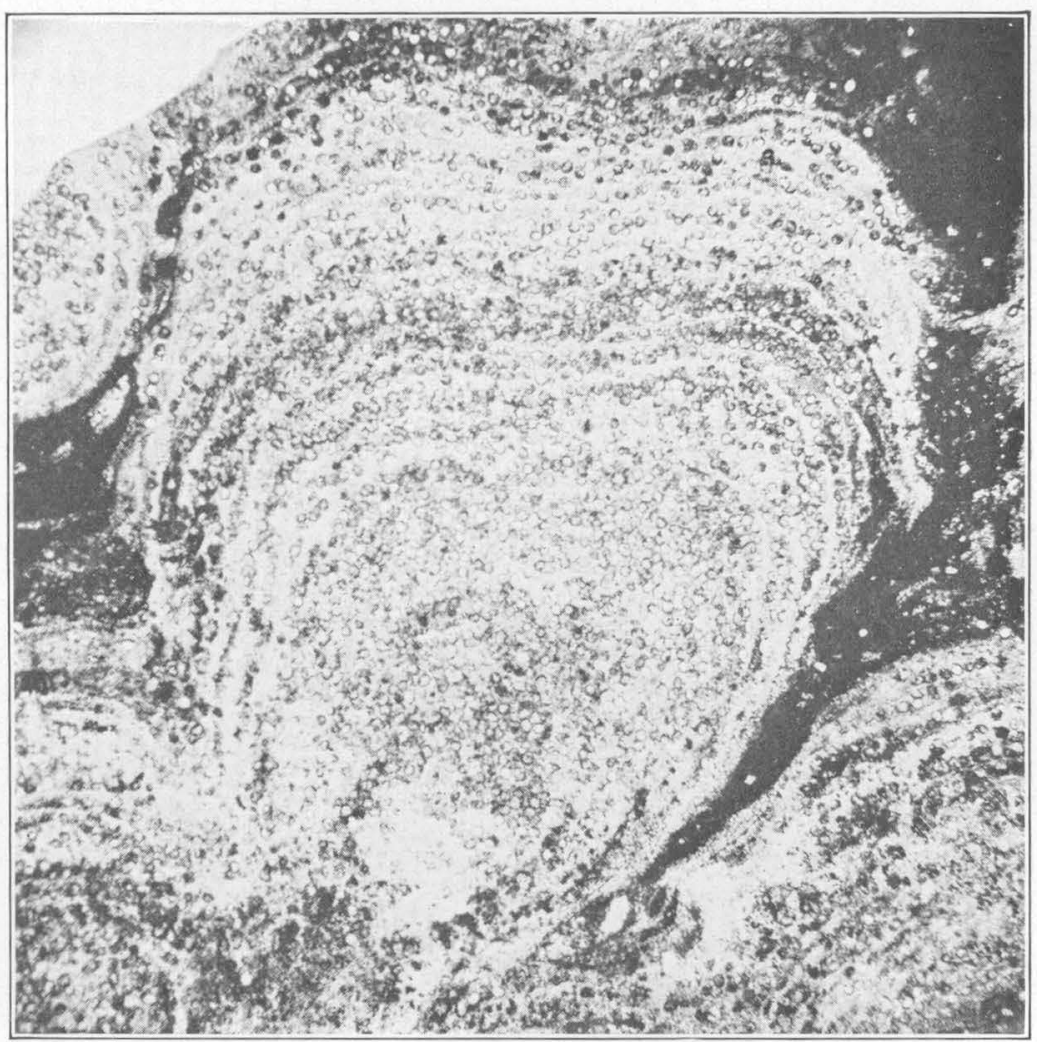

B. PHOTOMICROGRAPH OF TYPICAL LOBATE COLONY OF CHLORELLOPSIS COLONIATA REIS

Showing the vague layering of the unicells. Enlarged 10 diameters 


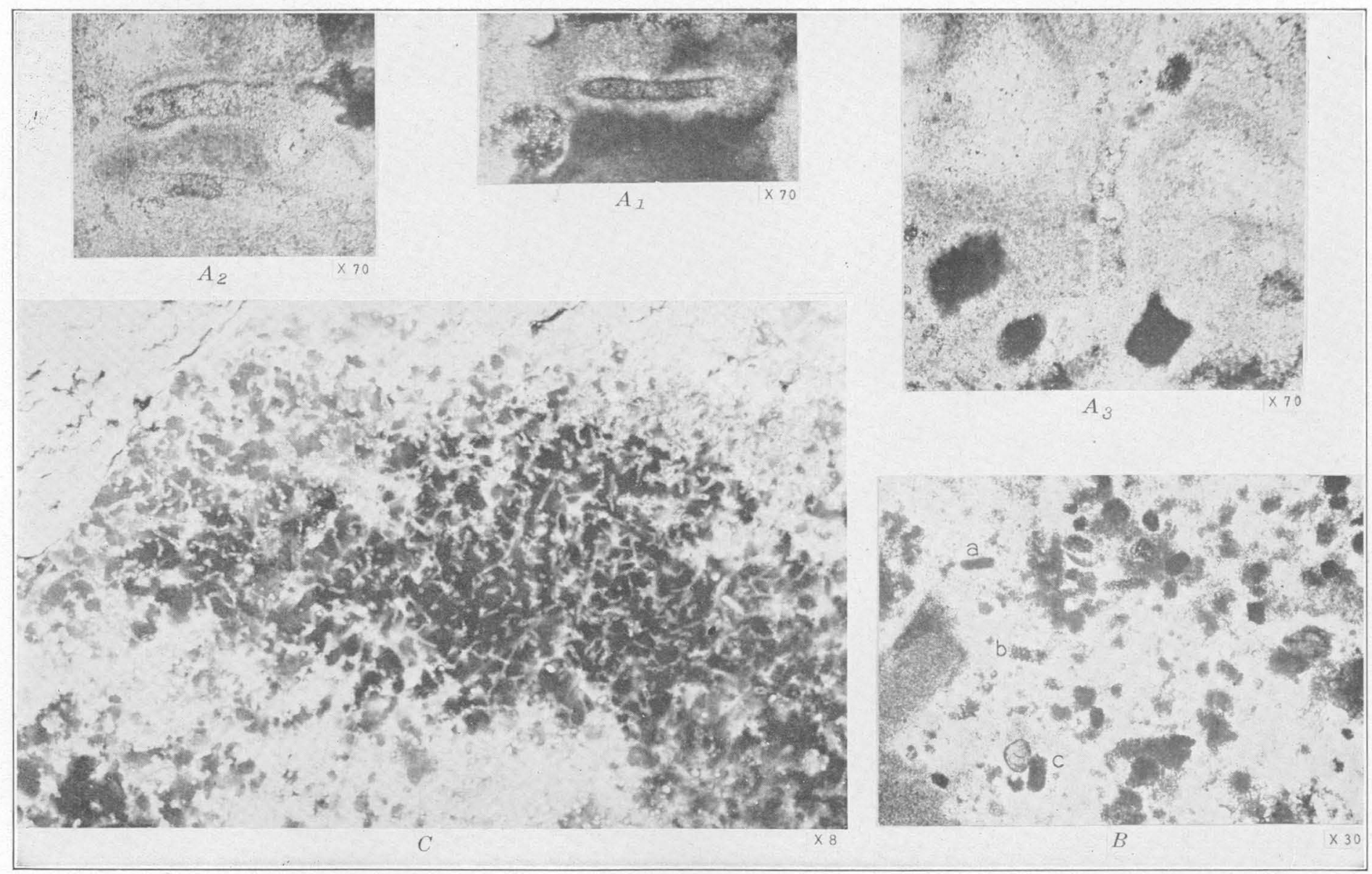

CONFERVITES MANTIENSIS AND ASSOCIATED COPROLITES

A. Photomicrographs of cellular parts of Confervites mantiensis Bradley, n. sp.: 1, Tip of a filament with quadrate cells and a bluntly tapered apical cell, resembling some species
of $L y \eta g b y a ; 2$, tip of a filament with large spherical cells and a wide sheath; 3, filament with intercalary heterocyst resembling Nostoc. B. Photomicrograph of small

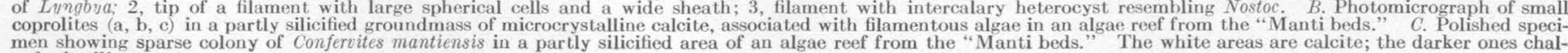
cedonic silica 


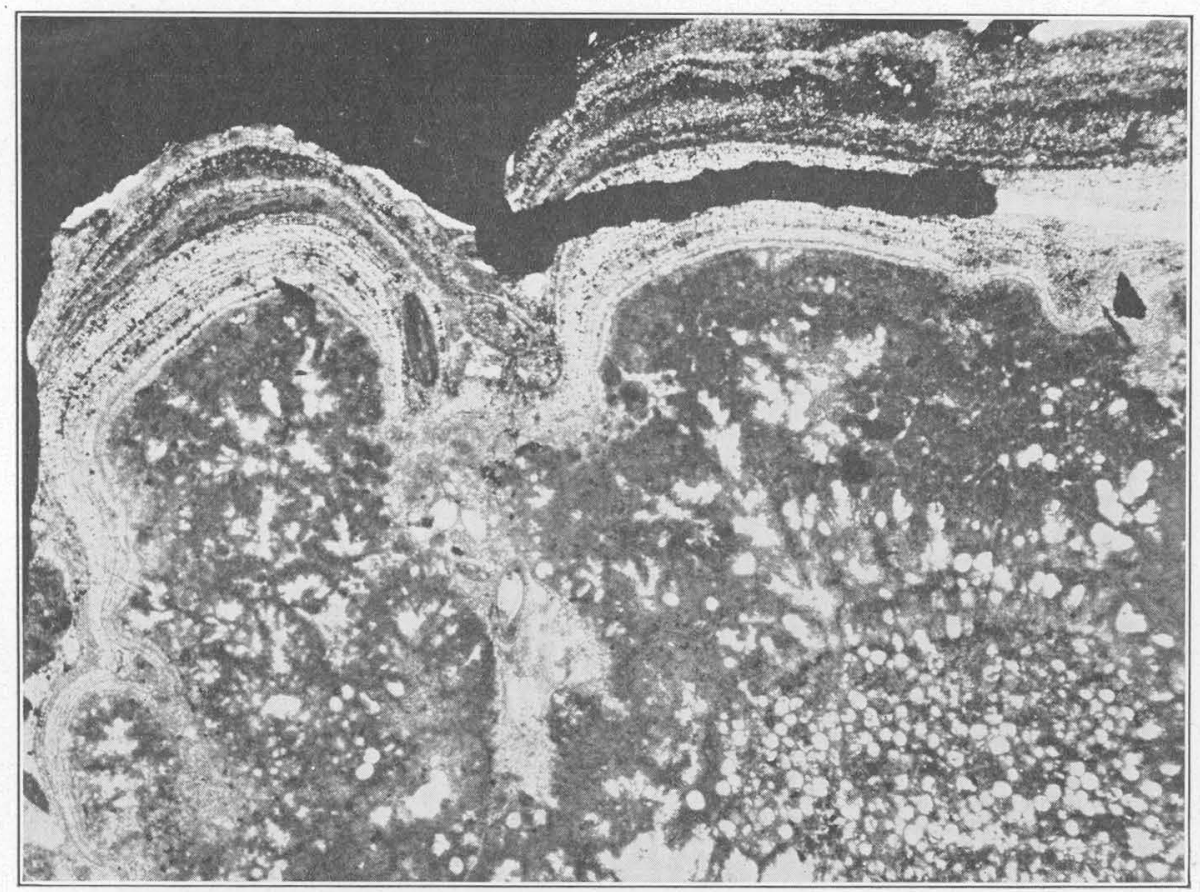

A. PHOTOMICROGRAPH SHOWING THE ASSOCIATION OF THE THREE PRINCIPAL TYPES OF STRUCTURE FOUND IN THE ALGAE REEFS OF THE GREEN RIVER FORMATION

Small area of the reef shown in Plates 43, A, and 45, A. In the lower right-hand quarter is a colony of the large spherical cells of Chlorellopsis colomiata Reis, above that is a thick zone of typical spongy deposit, and at the
top and also down the left side is an inorganic incrustation. Enlarged 10 diameters

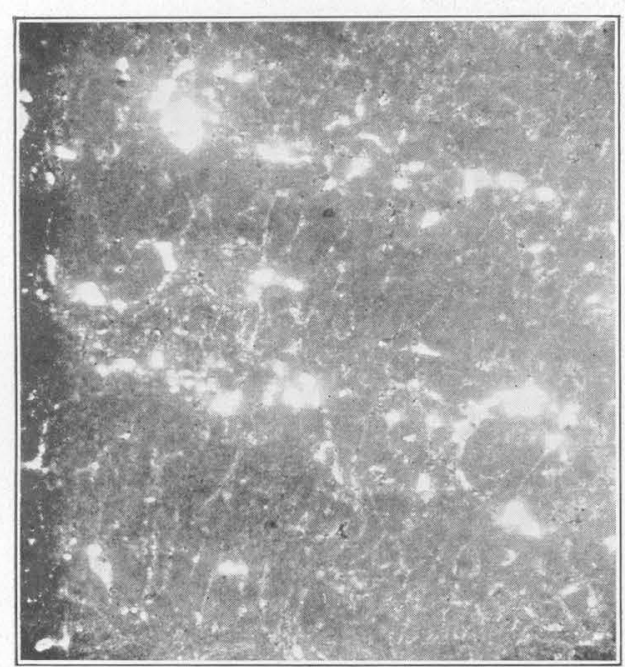

B. PHOTOMICROGRAPH OF PART OF AN ALGAE REEF

Showing thin radial lines of medium-grained calcite, which may be casts of filamentous algae. The matrix is a spongy algal deposit of microcrystalline calcite

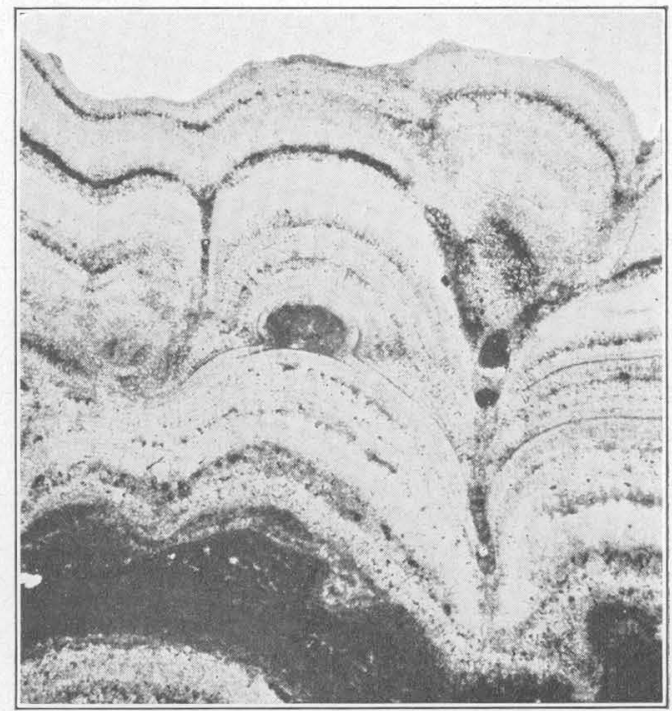

C. PHOTOMICROGRAPH OF TYPICAL PHYSICOCHEMICAL INCRUSTATION OF CALCITE

Showing the radial fibrous structure interrupted by thin concentric zones of limonite granules. The irregular black layer at the base and the small rounded cushion-shaped area opaque because they consist of calcite that is almost cryptocrystalline. Enlarged 10 diameters 


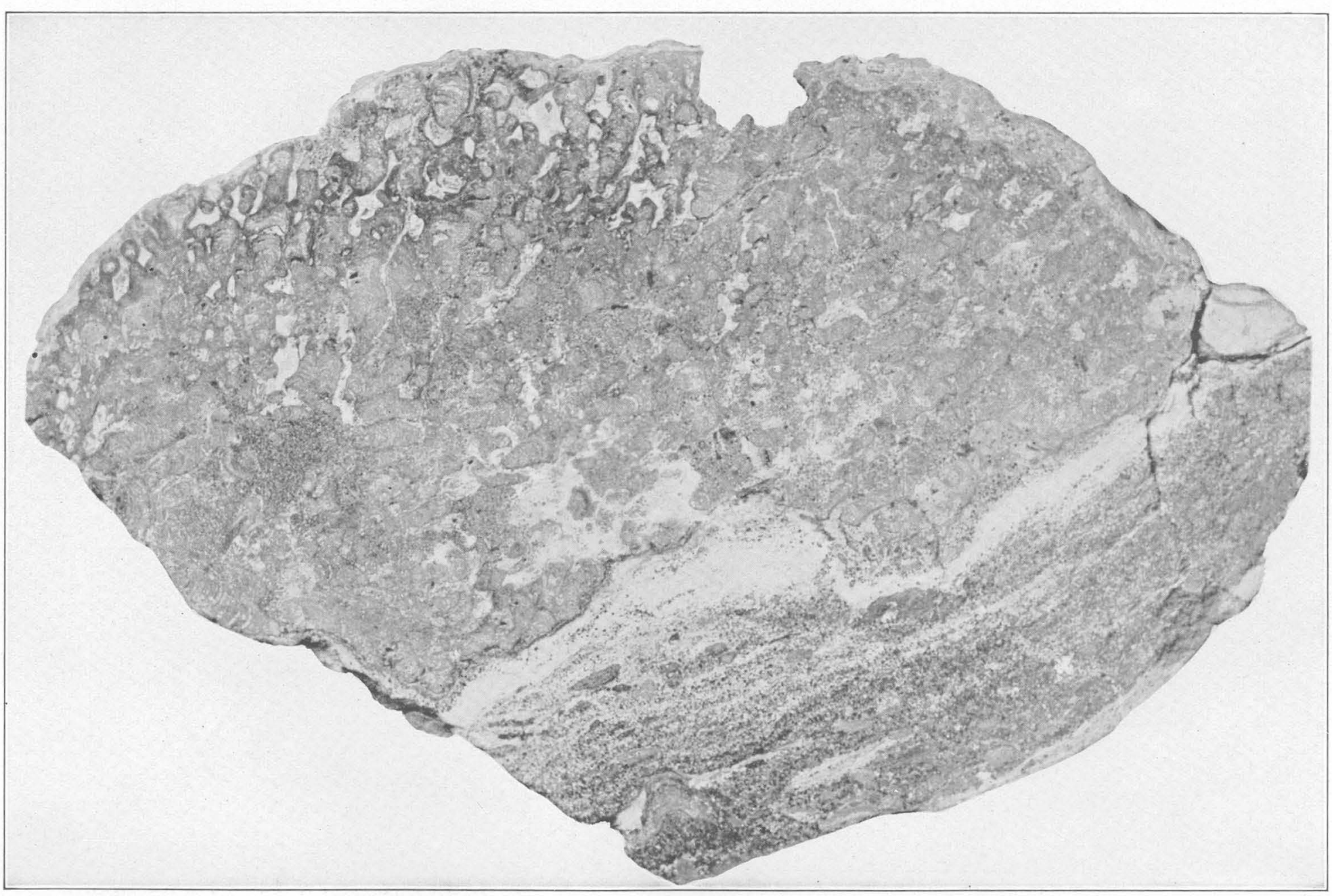

POLISHED VERTICAL SECTION OF A CHLORELLOPSIS REEF Showing the irregular and vaguely radial arrangement of the lobate algal colonies; also a part of the oolitic sandstone upon which it rested. The lightest-gray areas are fine-grained
sandstone, the black grains are oolite grains, and the medium-toned gray areas are fragments of silty limestone, alga reefs, and mud lumps. Natural size. 


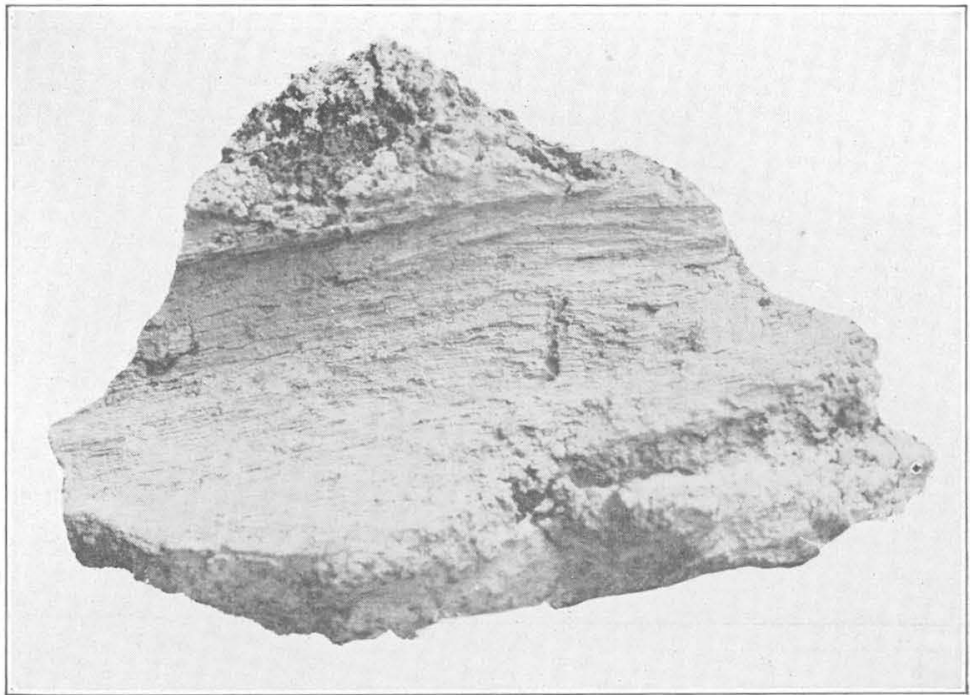

A. DEPOSIT FORMED AROUND WOOD BY CHLORELLOPSIS COLONIATA REIS

Natural size

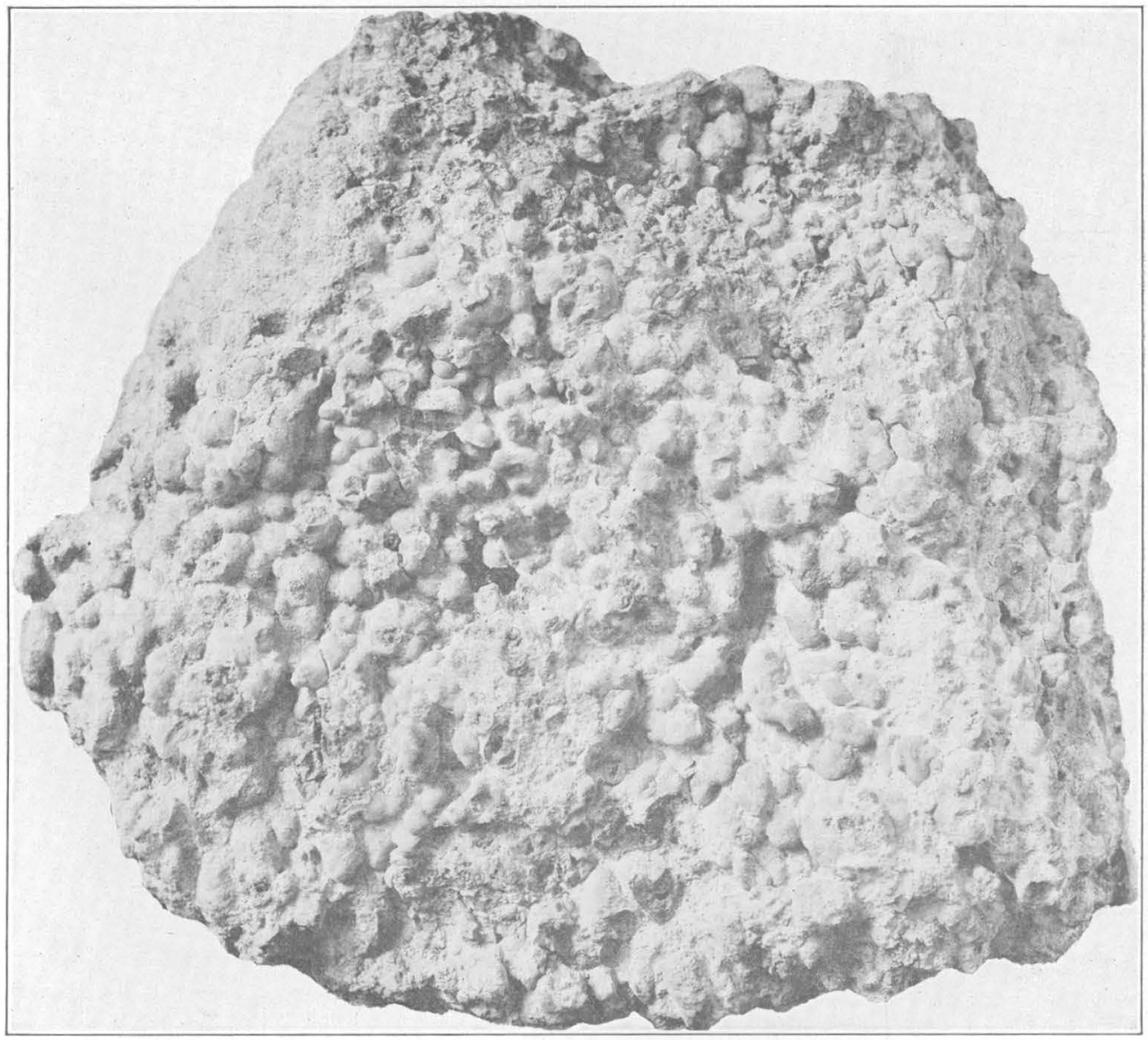

B. TUBERCULATE OR PAPILLATE EXTERIOR OF THE TYPE CHLORELLOPSIS COLONIATA REEF Each tuberele represents a single colony of algae. From the base of the Laney shale member of the Green River formation, NE. $1 / 4$ sec. 27 , T. 25 N., R. 103 W., Sweetwater County, Wyo. 


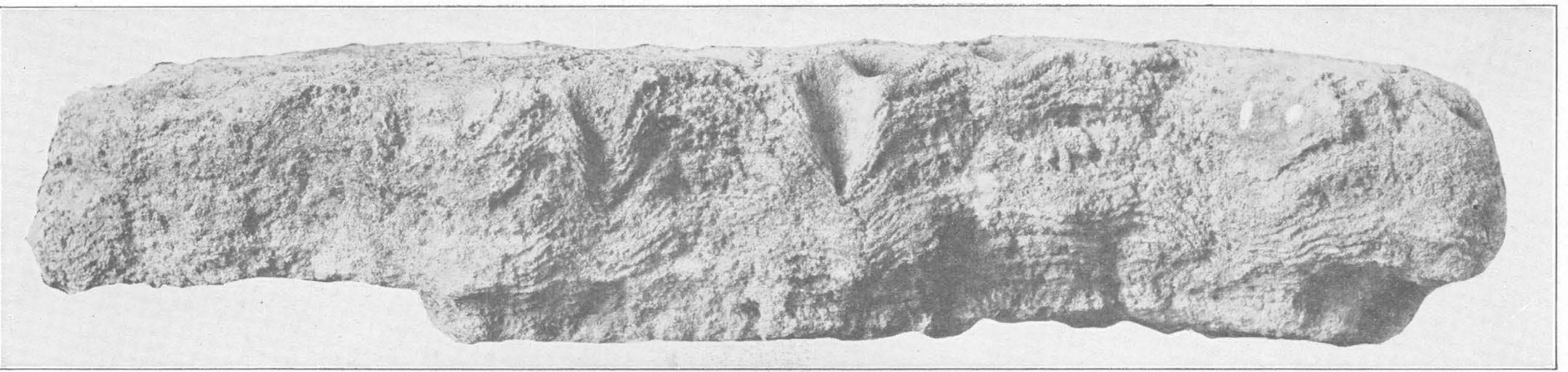

A. TRANSVERSE SECTION OF CHLORELLOPSIS REE

Showing the conoidal pits in section and the thinning of the algal layers toward the pits. Natural size

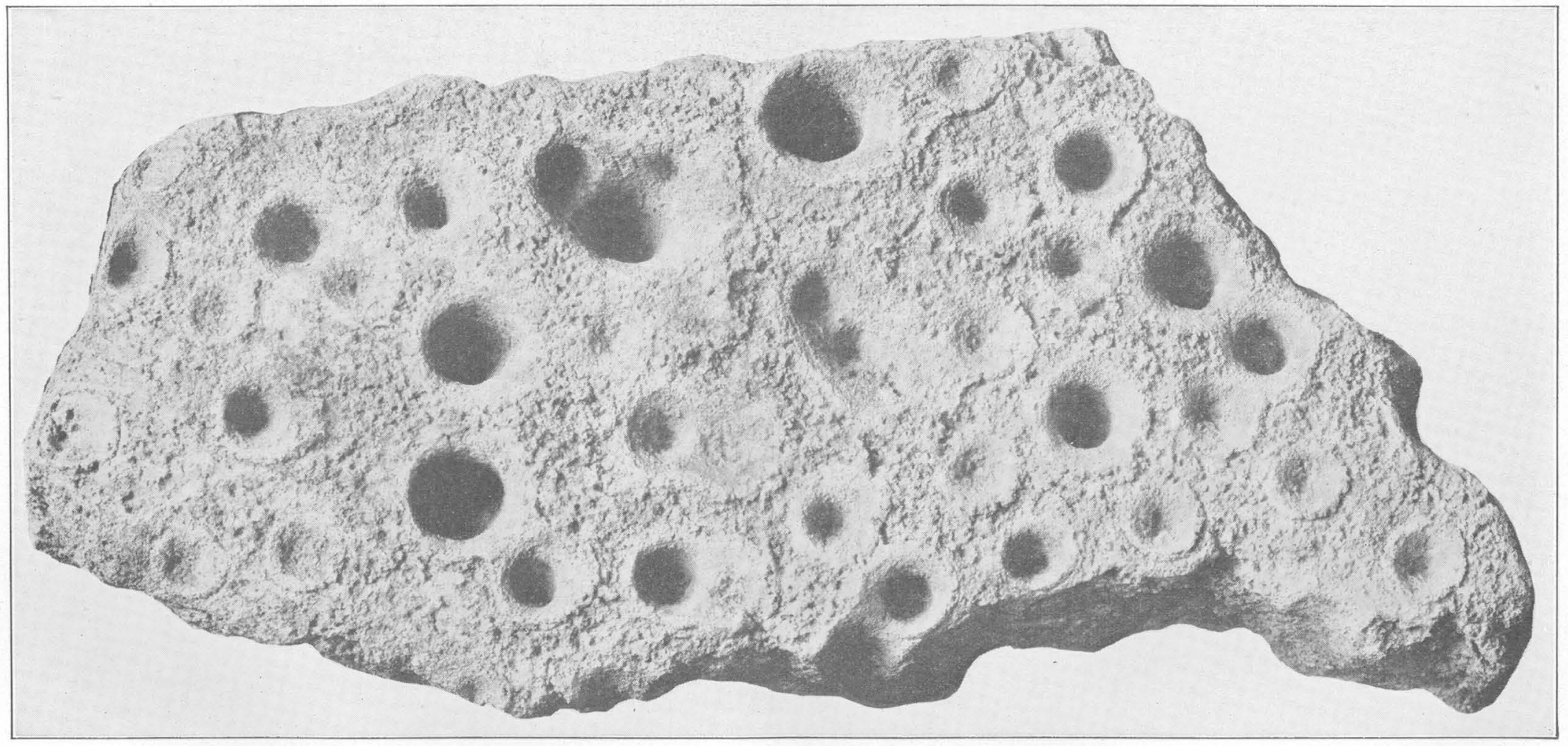

B. UPPER SURFACE OF CHLORELLOPSIS REEF

With conoidal pits showing their relative size and distribution and the difference in texture between the interior of the pits and the general surface of the reef. Natural size 


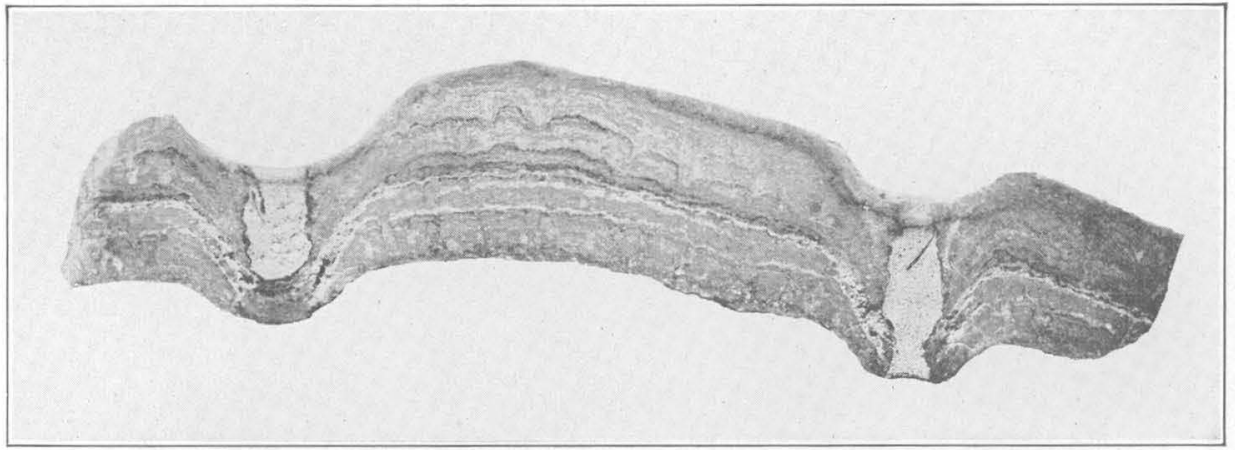

A. TRANSVERSE SECTION OF THE PITTED CHLORELLOPSIS REEF SHOWN IN $B$

Showing the cores of sand-filled ringed pits and the conoidal excrescences at their lower ends. This also shows the

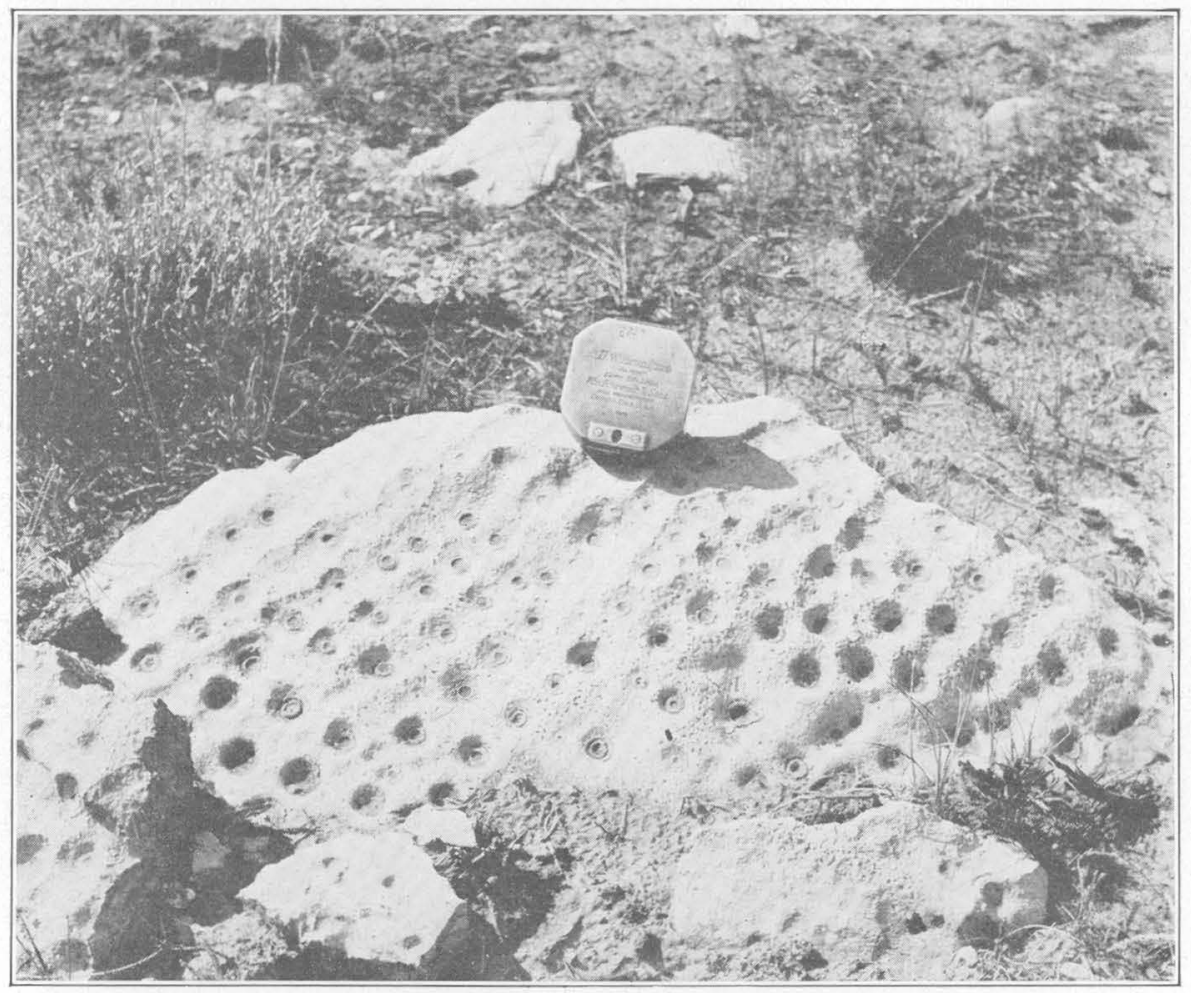

B. CUP-SHAPED, RINGED PITS IN THE UPPER SURFACE OF A CHLORELLOPSIS REEF

Showing their general uniformity of size and arrangement. At the left they are arranged in fairly definite
rows. The vermiculate surface between the pits shows best in a small area a little to the right of the rows. The vermiculate surface between the pits shows best in a small area a little to the right of the
center 


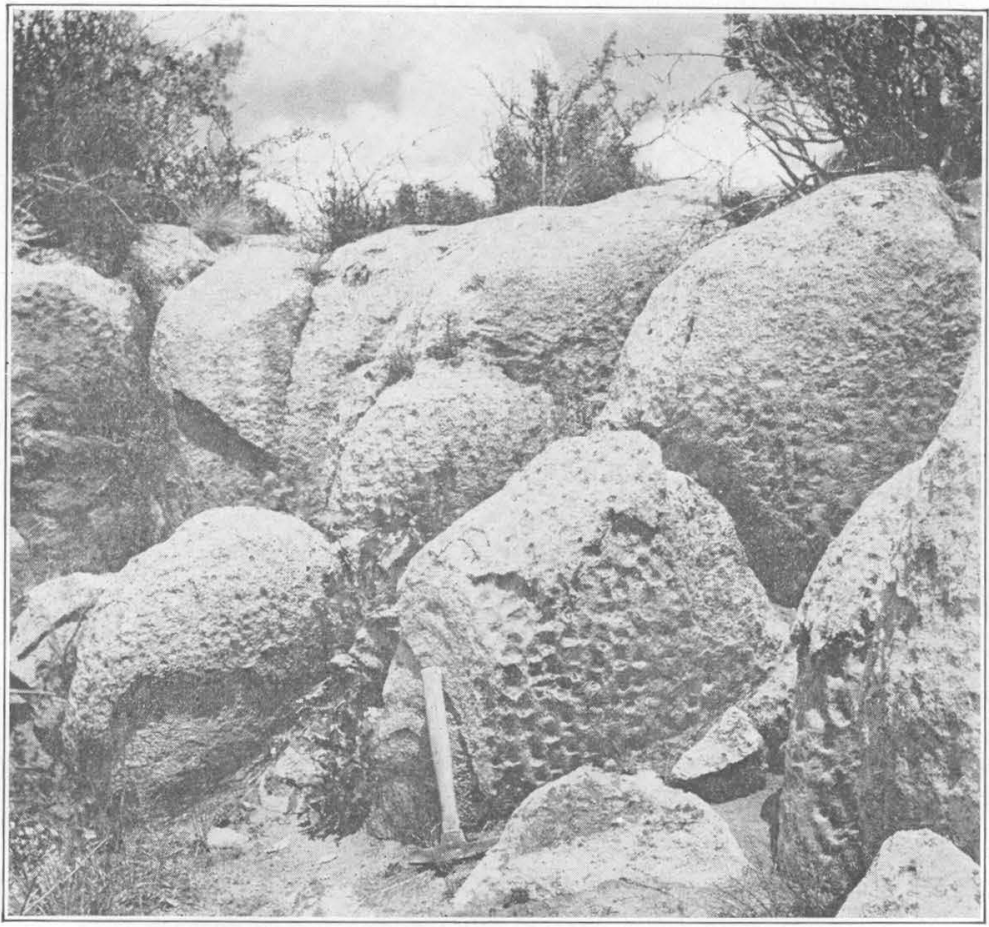

A. HEMISPHERICAL HEADS OF PITTED ALGAE REEF

Showing that the pit tubes are very nearly vertical, even where they emerge from the side of a head. The pits in the very steep sides of the head near the hammer make concave niches with nearly horizontal bottoms. The upper surface of the reef at this place is

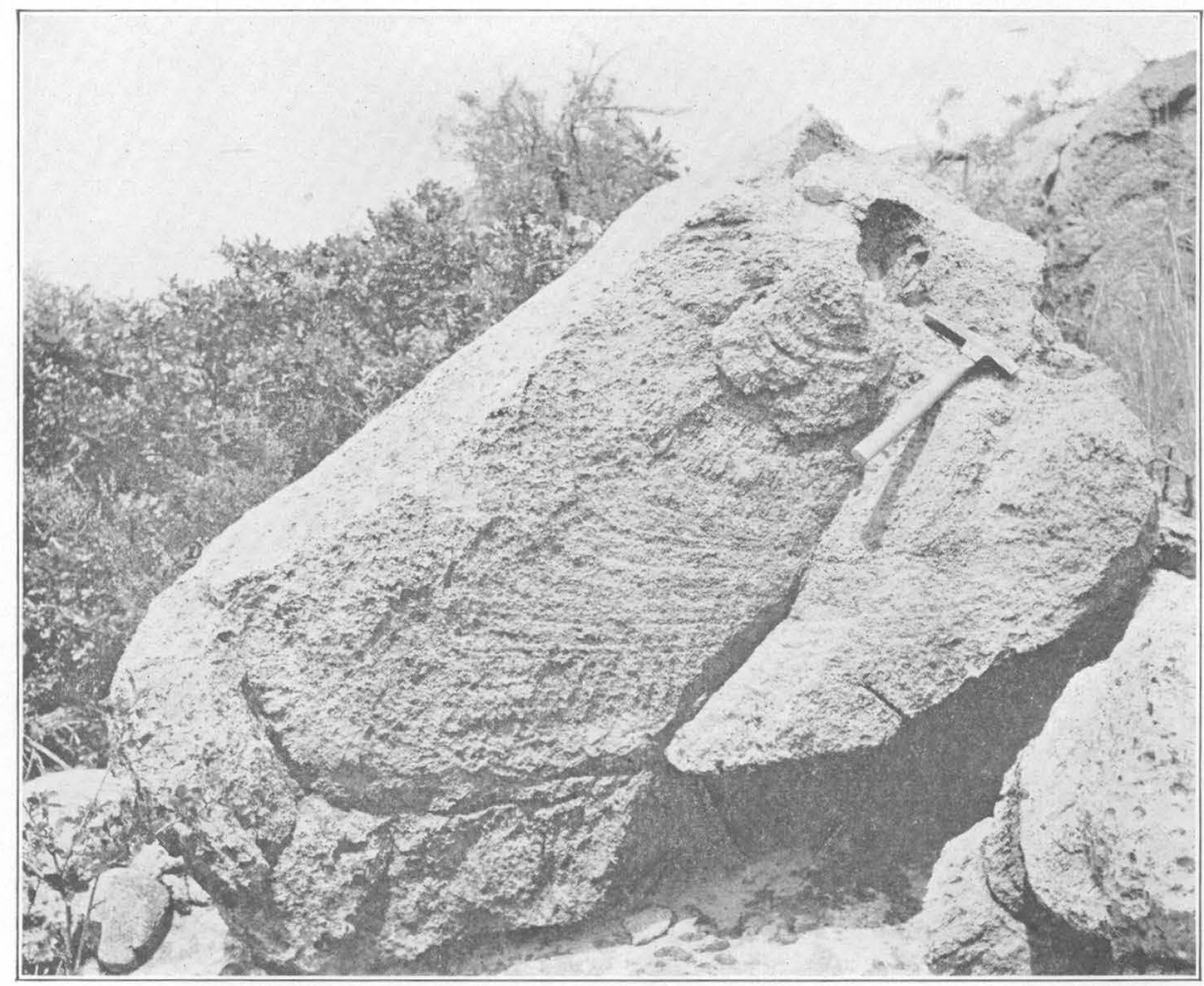

B. OVERTURNED AND BROKEN HEAD OF THE PITTED REEF SHOWN IN $A$

This shows, near the hammer head, a hole that contained the nucleus. It also shows the eccentric growth layers, which may be annual, and near the top of the head (the lower edge of the photograph near the because they were somewhat overgrown with algal deposits as the reef formed 


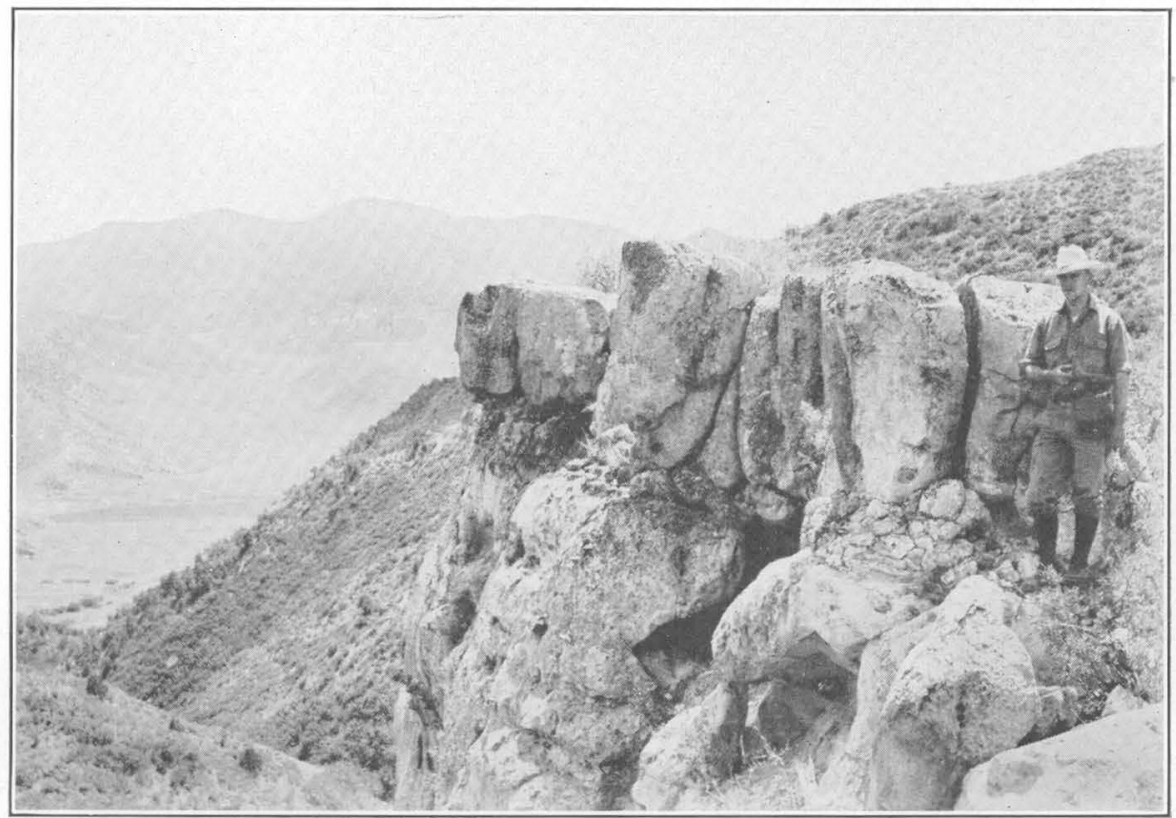

A. LARGE PITTED REEF CONSISTING OF SEPARATE, CLOSELY SPACED, TURBINATE HEADS WHICH REST UPON A BED OF SMALLER ALGAL NODULES

The nodule bed rests upon medium-grained massive sandstone that is locally cross-bedded. The second and third heads to the left of the man show fluting. The minimum time required for the formation of this reef is estimated at 355 years

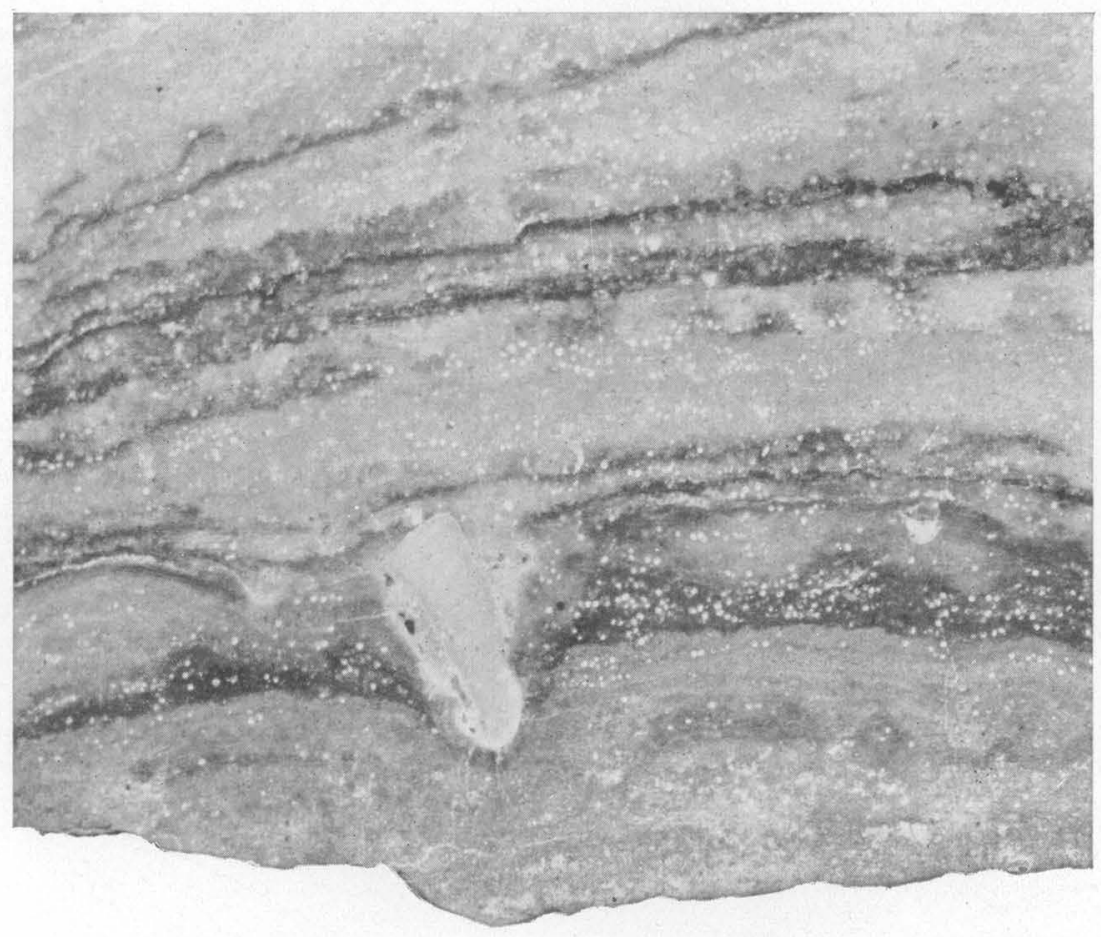

B. POLISHED VERTICAL SECTION OF A CHLORELLOPSIS REEF

Showing a large flat algal colony in part broken and in part deeply indented by a fragment of limestone that fell on it while the deposit was forming. Enlarged 5 diameters 


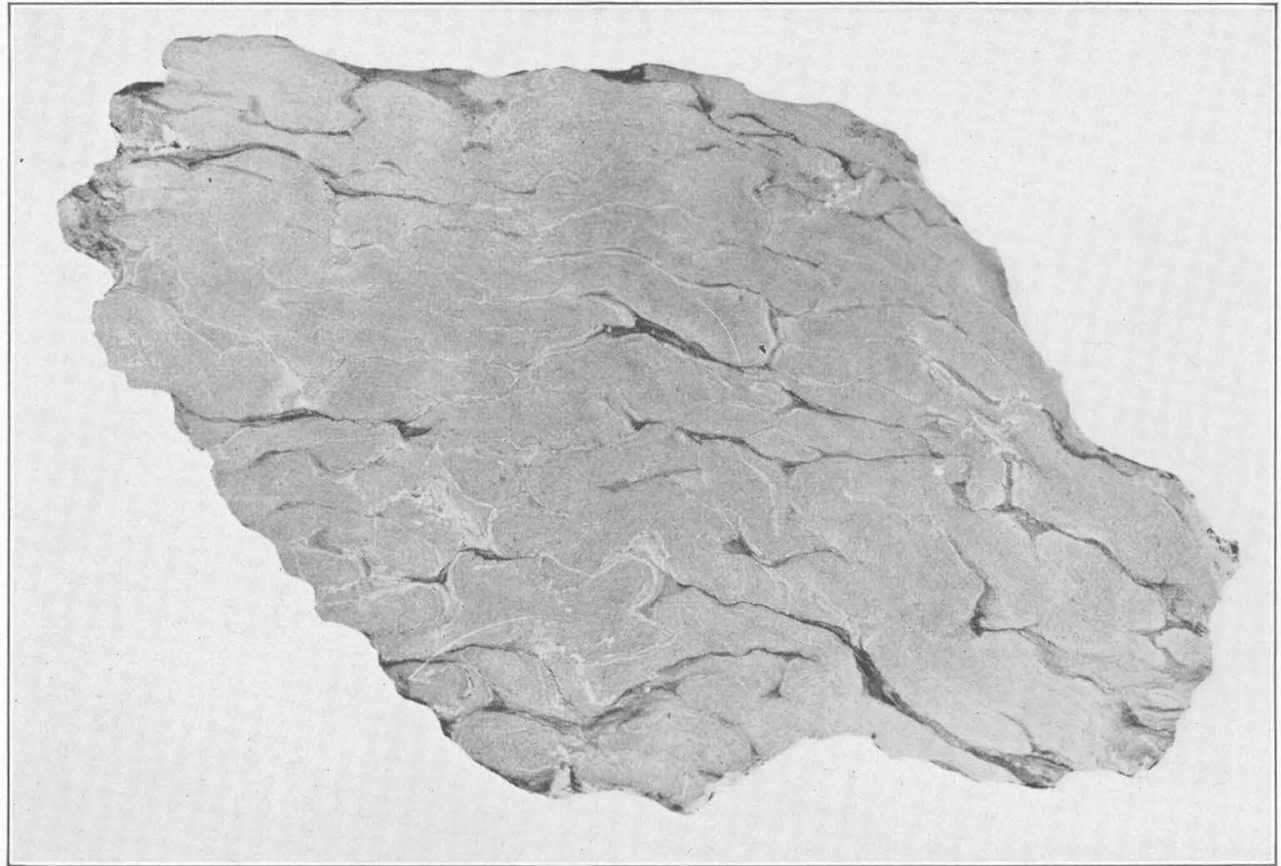

A. POLISHED VERTICAL SECTION OF A REEF FORMED OF RECUMBENT DISCOID COLONIES OF CHLORELLOPSIS COLONIATA REIS

The colonies near the center and upper parts of the specimen show faintly the concentric growth layers, which are convex outward along the radii of the colonies. Natural size

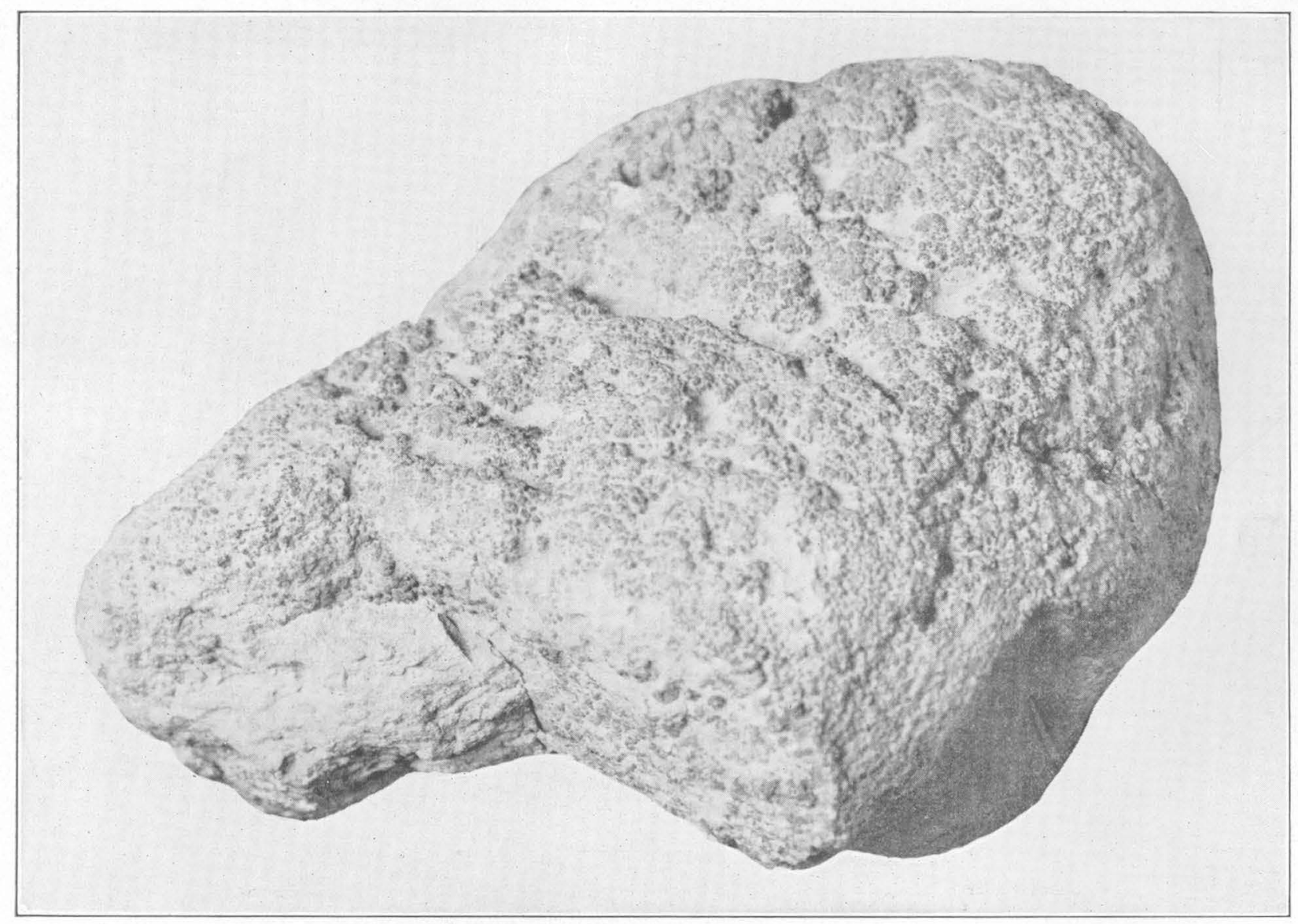

B. ISOLATED ALGAL HEAD WITH DIGITATE SPONGY STRUCTURE

Resembles in form and sculpturing the marine Lithothamnion. Natural size. See also Plate 42, $A$ and $B$ 
Roddy, ${ }^{21}$ Jones, ${ }^{22}$ and others. Jones ${ }^{23}$ also illustrates clearly a deposit of this type now being formed in Salton Sea.

Although algae were apparently the active agents that localized the precipitation of the calcium carbonate and gave the deposit its characteristic botryoidal form and eccentrically layered structure, the resulting reefs are not strictly comparable to those built up predominantly of casts or molds of algae such as Chlorellopsis coloniata Reis or various marine Corallinaceae. They are really only pseudomorphs of the original botryoidal algal colonies and not fossil algae like the others, which retain not only the outward form of the colony but also the form and some of the structural details of the individual plants.

\section{PHYSICO-CHEMICAL INCRUSTATIONS}

A few reefs of the Green River formation contain layers whose origin is more obscure. These layers consist wholly of tiers of radially arranged acicular crystals of calcite separated by thin layers of granular calcite and limonite grains and show neither organic structure nor the characteristic spongy structure just described. (See pl. 34, C.) Moreover, these layers appear to line cavities in the reefs and in a few places fill shallow cracks. They resemble layers of algal deposit in thinning and in places wedging out on the steep or overhanging sides of dome-shaped protuberances, but unlike the algal deposits many continue as thin incrustations into the bottoms of pocket-like depressions or infolds and up the sides of the adjoining excrescences. Furthermore, they differ from layers that are patently algal in tending toward a simpler surface form where many are superimposed. They fill the invaginations between algal colonies and bridge gaps between them, and above such bridges each succeeding layer becomes more uniform in thickness and so smooths out the surface contour. (See pl. 45, A.) Where these layers are of essentially uniform thickness the junction between arcuate sections of them is virtually a straight line. This feature resembles agate structure much more closely than algal structure. (See pl. $34, C$.)

In describing similar finely banded agate-like deposits which coated gastropod shells Bucher ${ }^{24}$ pointed out that the insides of the shells were also incrusted and that as the interior of the shell was dark the deposit could hardly have resulted from the photosynthesis of algae.

The radially fibrous layers in the reefs of the Green River formation may perhaps be recrystallized deposits localized by algae like Schizothrix rupicola Tilden or

2t Roddy, H. J., Concretions in streams: Am. Philos. Soc. Proc., vol. 54, pp. 240-258, 1015.

82 Jones, J. C., Quaternary climate; Geologic history of Lake Lahontan: Carnegic Inst. Washington Pub. 352, pp. 6-14, 1925.

98 Idem, pl. 1, flg. 10.

24 Bucher, W. H., Ửber einige Fossilien und über Stromatolithbildung im Tertiür dor bnyerishchen Rheinpfalz: Geognostische Jahresh., vol. 26, p. 79, 1918.
Chantransia pygmaea (Kützing) Sirodot, which according to Tilden ${ }^{25}$ grow in weak light and deposit calcium carbonate. It is also possible that these layers of radial acicular crystals were formed by repeated exposure to the air, as at the lake shore, where they would be alternately moistened with lime-bearing water and dried. There is, however, no evidence to substantiate this supposition. It seems much more probable that they were formed without the assistance of plants and represent physicochemical deposits formed rapidly upon the algal layers as substrata.

Bucher ${ }^{26}$ has produced thin layers of this kind experimentally and in further support of the hypothesis of their inorganic origin points out ${ }^{27}$ that they are connected by all stages of transition with oolites for which he has adduced convincing arguments of an inorganic origin.

\section{REEFS BUILT CHIEFLY OF CHLORELLOPSIS}

The molds of the simple alga Chlorellopsis coloniata make up the greater part of many algae reefs of the Green River formation. These reefs have a variety of forms and internal structure. The specimens described below have been chosen as representative of the distinctive varieties.

\section{TYPE CHLORELLOPSIS REEFS}

The typical Chlorellopsis deposits (pls. $35 ; 36, B$ ) form reefs of huge puffball-shaped heads 0.7 to 1.7 meters $\left(2 \frac{1}{2}\right.$ to $51 / 2$ feet) high and 0.6 to 0.7 meter (2 or 3 feet) in diameter. They also occur as isolated ellipsoidal heads 0.3 to 0.9 meter ( 1 to 3 feet) in maxjmum dimension and as thin layers of small extent whose lower surface is flat but whose upper surface is vigorously nodose.

Some of these reefs are inclosed in beds of very fine grained oolite mixed with fine sand, some in finegrained current ripple bedded sandstone; others rest on limy shale that contains scattered oolite grains and are overlain by hard greenish-gray pyritiferous shale that shows only obscure bedding. White silty limestone contains nodular masses of the type deposit in parts of the formation in Wyoming. The surfaces of the reefs differ somewhat, but most are irregularly vermiculate or verruculose, with protuberances 2 to 4 millimeters high. A few have markedly tuberculate surfaces. (See pl. 36, B.)

Vertical sections of these reefs show that they consist of an aggregate of closely spaced or intergrown, very irregular, elongate simple or branched lobes that are crudely elliptical in cross section. These range in diameter from 2 to 7 millimeters near the base and taper slightly to a rounded tip. Some are expanded laterally.

${ }^{25}$ Tilden, J. E., Some new species of Minnesota algae which live upon calcareous or siliceous matrix: Bot. Gazette, vol. 23, pp. 102-103, 1897.

${ }^{26}$ Bucher, W. H., On oolites and spherulites: Jour. Geology, vol, 26, p. 608, 1918. ${ }^{27}$ Idem, pp. 593-604 
into leaf-like forms about 5 millimeters thick and as much as 20 millimeters across. The lobes have a crudely radial arrangement but no definite base or substratum and are not arranged in definite layers. The largest are about 3.5 centimeters long. A few branch dichotomously at an acute angle, but most of them bear short thick protuberances directed at a rather wide angle away from one side. (See pl. 35.)

Microcrystalline quartz and chalcedony have filled the spaces between the lobes of some reefs; fine limy oolite grains, fine sand, or silty limestone fill them in others.

Thin sections show that these lobate bodies consist of many successive limpet-shaped colonies of Chlorellopsis coloniata, some of which are very highly arched and decidedly asymmetric. (See pl. $32, B$.) Their growth was evidently periodic. Each colony represents a brief period of growth and is separated from the next succeeding colony by a thin even layer of microcrystalline calcite, which was probably deposited without the agency of plants in an interval of lessened or no algal growth.

The groups of àlgal colonies or lobes taper upward slightly, pinch and swell, or retain about the same size but do not swell out into bulbous or saclike masses with overhanging sides, as if they had had plenty of space to expand. This restricted habit is due partly to their close spacing, and yet in parts of the deposit where they are much more widely spaced they retain the same habit. Apparently there was also another factor that prevented lateral expansion of the colonies. If the limy mud or fine oolite and sand grains accumulated nearly as rapidly as the algae grew, then in order to maintain themselves they. would probably have built chiefly upward-expanding if possible, contracting if necessary. Such a mode of growth would account for their irregular tuberoid form. Moreover, the groups of algal colonies are not definitely arranged as if there had been a substratum upon which all the colonies were established at once and flourished unhindered. Instead their bases are at various heights above the base of the reef, indicating that they are not all colonies of the same age and that the substratum upon which the successive new colonies started was continually being raised.

The fine-grained and sandy oolite beds in which some of these reefs occur indicate shallow water activated by moderate currents or waves, for the oolite grains, which average about 0.5 millimeter in diameter, have been transported; they are gently cross-bedded and are mixed with fine clean sand that contains fishbone fragments. Locally there are also small groups of oolite grains in their original matrix, indicating that the jelly-like ooze in which they were formed had at least partly solidified before the grains were disturbed and transported. The grains within these small pieces of dense calcite do not touch one another but appear to have been suspended. Coarse angular mud flakes and considerable limonite in the oolite beds suggest also that the water was very shallow. At other places, however, quieter water is indicated, as the reefs rest upon limy shale with oolite grains and are covered by shale.

One zone of ellipsoidal heads and nodules of this type was found approximately at the top of the basal unit of the Green River formation at the southwest corner of sec. 30 , T. 1 N., R. 95 W., Rio Blanco County, Colo. A reef of great puffball-shaped heads occurs also in the upper part of the basal unit about 101 meters (330 feet) above the base of the formation along the road from Fruita to Rangely near the divide between Douglas and East Salt Creeks, Colo. A layer of discrete ellipsoidal heads from 4 to about 25 centimeters in diameter, of a very porous algal deposit of this kind, occurs between a large pitted algal reef and a thick, massive medium-grained sandstone bed in the NW. $1 / 4$ SE. $1 / 4$ sec. 26 , T. 4 N., R. 96 W., Moffat County, Colo. (See pl. 13, A.) In Sweetwater County, Wyo., in the NE. $1 / 4$ SW. $1 / 4$ sec. 14, T. 25 N., R. 103 $\mathrm{W}$., there is a reef of this type at the base of the Morrow Creek member of the Green River formation. Subangular fragments of a silicified reef were found in a remnant of coarse bench gravel at the top of the Tipton tongue of the formation at the north quarter corner of sec. 1, T. 24 N., R. 100 W., Sweetwater County, Wyo. The horizon which these pieces represent is unknown.

\section{MODIFICATIONS OF THE TYPE}

An unusual algal deposit whose internal structure is closely similar to the type just described was also found in Sweetwater County, Wyo. It formed dense incrustations around logs and branches, and some of the incrustations were as much as 60 centimeters (2 feet) in outside diameter, 20 to 25 centimeters ( 8 to 10 inches) in inside diameter, and 1.8 to 2.4 meters (6 to 8 feet) long. The outer surface of the deposit is minutely nodose or papillose. The surface next the wood bears a very sharp impression of the woody fibers and in places has retained the cellular structure. (See pl. 36, A.) Apparently the bark had fallen away and the wood had started to decay, as is shown. by the crudely rectangular depressions which the limy deposit filled. Thin sections of the deposit show that it consists of lobate colonial groups of Chlorellopsis coloniata that are of the same form as those of the type deposit but have a definite radial arrangement. Microcrystalline calcite that contains scattered angular grains of fresh plagioclase feldspar fills the interstices between the lobes and also obscures the verruculae which the tips of lobes would otherwise make. The papillose surface is due simply to differential weathering and is not structural, as in the reefs described on page 209. These algal deposits which 
incrusted logs were associated with an irregular reef that has a similar internal structure. They were found in the Tipton tongue of the Green River formation in the SE. $1 / 4$ sec. 23 , T. 25 N., R. 103 W., Sweetwater County, Wyo.

Another algae reef closely related to the type Chlorellopsis reefs described on pages 209-210 occurs 286 meters (940 feet) above the base of the Green River formation in the NE. $1 / 4 \mathrm{SE} .1 / 4$ sec. 30, T. 4 N., R. 96 W., Moftat County, Colo. It forms hemispherical heads 1 to 1.3 meters ( 3 to 4 feet) in diameter which are made up of concentric "shells" 4 to 6 centimeters thick. The reef rests upon a thick unit of finegrained buff to gray soft sandstone which is current: ripple bedded throughout and is overlain by finegrained but somewhat shaly sandstone. The upper surface is vermiculate or verruculose. The under side has a very spongy aspect and consists of closely spaced or intergrown subcircular tubercles whose tips are either concave or contain conoidal depressions that apparently conform to the nodose surface of the underlying "shell." A polished cross section shows that the reef consists of tiers of radially arranged irregular clavate to bulbous groups of Chlorellopsis coloniata colonies, some of which are bifid. Most of the spaces between colonial groups or lobes are filled with mediumgrained sand mixed with ostracode valves, but some are empty, and some contain dense buff calcite, probably of inorganic origin, which is similar to the thin layers that separate the tiers of algal colonies.

\section{PITTED CHLORELLOPSIS REEFS}

Algae reefs with large, distinct pits (pls. $37, A$ and $B ; 38, A$ and $B ; 39, A$ and $B ; 40, A$ ) are apparently peculiar to the Green River formation of Colorado. They were not found in that formation in Utah nor in Wyoming, and as yet the writer has found no mention in the literature of any comparable algal deposit.

Walcott's pre-Cambrian genera Greysonia and Copperia ${ }^{28}$ contain large tubes. filled with extraneous material, but in them the part regarded as algal is smallso small, indeed, that the deposits are utterly different from those of the Green River formation. These Eocene deposits form reefs of considerable extent which are 0.3 to 1.8 meters ( 1 to 6 feet) thick and consist of closely appressed hemispherical or turbinate heads. They are interbedded with algal deposits of other kinds or occur between thick beds of clean light-gray medium-grained cross-bedded sandstone.

Circular pits of two distinct kinds cover the upper surfaces and in part also the sides of the heads. Those of one kind are shallow, cup-shaped, and fairly uniform in size and contain a more or less prominent raised concentric ring or collar in the bottom. In a few there are two such concentric rings. (See pl.

${ }^{28}$ Walcott, C. D., Pre-Cambrian Algonkian algal flora: Smithsonian Misc. Coll., vol. 64 , pp. 108-110, pls. 17-19, 1914.
$38, B$.) Within the ring is another pit, circular or obovate in section, which is the end of a sand-filled tube that extends down into the reef. In some parts of the reef the pits are about equally spaced and without definite arrangement, but in other parts they have a distinct linear arrangement in the rounded bottoms of troughs. (See pl. 38, B.) Sharp but somewhat sinuate crests separate these troughs. The entire surface is vermiculate and resembles rather closely the surfaces of the type Chlorellopsis reefs. The under side of an eccentric shell of this type of pitted reef bears rounded, conoidal excrescences, each with a crater-like pit at the top which is the other end of a sand-filled tube or core of a surface pit.

The pits of the other kind are simply cone-shaped depressions with rounded bottoms. They may be very shallow or deep. Near the surface the cone flares, forming a sort of border for the pit. This collar and the inside of the cone have a granulose texture; which contrasts with the rather coarsely faveolate surface of the reef. (See pl. 38, B.) These pits differ widely in size and have no regular arrangement, although most of them are about equally spaced. The under side of a pitted reef of this type is marked with deep crater-like pits in the tops of low, steep sided cones.

In cross section the pitted reefs show rather thick and porous or cellular growth layers. These consist of fine-grained buff calcite and are arched between the pit cores, being more highly arched the more closely the cores are spaced. Many pit cores extend through at least one "reef shell," 5 to 12 centimeters, but others go only about 1 centimeter below the bottom of the pit. (See pl. 38, A.) The writer does not know what the maximum length of these tubes may have been. The heads of some reefs are clearly fluted for 3 feet or more from the top, and these flutings end in ringed surface pits. (See pl. 40, A.) Broken fluted heads show that many of the tubes are both long and wide. Those shown in Plate 39, $B$, are 2 or 3 centimeters in diameter, only a little smaller than the surface pits.

The tubes of the ringed pits are filled with clean fine-grained sand compactly cemented with clear calcite. Small fishbones and a few ostracodes are scattered through these cores. The tubes of the conoidal pits are less distinct, having been largely overgrown by algal deposits from the sides and filled with small pellets of algal limestone and fine oolite grains.

Under the microscope the two kinds of pitted deposits appear to be essentially the same. They consist of superimposed long botryoidal layers of Chlorellopsis coloniata Reis separated by irregular layers and lunate zones of somewhat spongy microcrystalline calcite, which shows a network of radially arranged, interlacing fine lines of more coarsely crystalline calcite. (See pl. 34, B.) Scattered through this organic structure are many small pockets and stringers of 
angular quartz and fresh orthoclase feldspar grains some of which are as much as 0.3 millimeter in diameter. These detrital grains are in a matrix of clear, finely granular calcite.

In certain zones in the reefs the colonies are more or less isolated, tall, columnar, and branched and give those zones a coarsely spongy aspect. This different habit was apparently caused by an accumulation of medium-grained sand and cyprid ostracode valves, in the hollows between colonies, which nearly kept pace with the algal growth.

In some reefs the algal deposits and also laminae of dense structureless limestone that coat them are considerably brecciated. The angular fragments, mixed with a generous proportion of fine sand and limy ostracode shells, form distinct layers within the reefs. Such structure indicates that the limestone of both kinds became hard and brittle comparatively soon after its deposition and that these reefs grew where at intervals waves and currents were active.

Clearly these deposits grew periodically by the addition of alternate layers of algae molds and precipitates of finely divided calcium carbonate. The algae grew freely, for their extensive layer-like colonies also expanded upward into comparatively broad domelike forms. Filamentous algae apparently also flourished and formed somewhat compressed hemispherical colonies among and on top of the Chlorellopsis colonies.

Toward the tubes the colonies thin very decidedly and in that way form the tube pits, for obviously the area immediately surrounding a tube built up much less rapidly than the other parts of the deposit. Consequently also the thinned edges of the colonies must dip more and more steeply into the pits as the deposit increases in thickness. In some reefs these edges dip inward at angles as large as $65^{\circ}$ from the horizontal. The conclusion is inescapable that the immediate vicinity of these pit tubes was distinctly less favorable for the growth of the lime-depositing algae than areas more remote from the tubes. In fact, it appears that the growth of the algae was inversely proportional to the proximity of pit tubes.

The reasons for the greatly restricted growth of algae near the tubes are not clear. One possible explanation is offered. The tubes are all vertical or very nearly so, even though they emerge from the very steep sides of a large columnar head of a thick reef. (See pl. 39, A.) They are also fairly uniform in diameter, mostly 0.75 to 1.75 centimeters. None larger than 3 centimeters in diameter have been observed, but in places where they are rather closely spaced, as between two of normal size, there are tubes as small as 3 millimetersin diameter. This persistently vertical habit, the variation of size within fairly definite limits, and especially the spatial relations of small to large tubes, together with their fairly regular circular or slightly elliptical cross section, suggest that the tubes are molds of a large sedge such as Scirpus lacustris, the common bullrush that grows profusely in the shallow water along lake shores. If the tubes were formed in that way, then the zone around the sedge stems may have been less favorable to the algae by reason of the reduced illumination at all times except when the incident light was practically parallel to the sedge stalk. The most luxuriant growth of algae in the widest spaces between tubes accords with the suggestion of light control. Sand and other detrital material may well have filled the tubes after complete decay of the sedges when reef building ceased and the deposit was buried by the overlying sediment.

Although this explanation may serve to elucidate the distribution of the algae and consequently also the formation of the pits, it is not wholly convincing as to the origin of the tubes, because there is no trace of the stout rootstocks of a sedge. Further search might reveal them at the base of the reef, and yet it is inconceivable that a single stand of sedges could have persisted while more than 2 meters of algal limestone was formed around them. It is, however, barely possible that the rootstocks grew in the limy mud at many successive levels in the reefs, and that as they were horizontal and below. the surface of the deposit they had little chance of being filled with sand, and therefore upon decay their molds collapsed and the limy mud settled in, thus obliterating all trace of them. Even the vertical tubes, where filled with microcrystalline calcite, are exceedingly obscure.

Although originally all conoidal, the surface pits have very probably been modified to the cup shape by solution, as they are excellent small water reservoirs. Moreover, the tops of some pitted reefs are so deeply weathered that the pits are nearly effaced. Only obscure rings show where the tubes end. (See pl. $39, A$.) Because fine to medium grained, well-sorted sand occurs between the algal colonies, because there are layers of finely brecciated algal limestone mixed with sand at several levels within the reefs, and because many of the reefs rest on sandstone or beds of oolitic and ostracode limestone which contain coarse broken fragments of algal limestone it seems very likely that these reefs were formed in shallow water, where currents and waves were at least periodically active. As the origin of the tubes can not be conclusively demonstrated they do not assist in interpreting the reef ecology.

The thickest and best-exposed pitted reef was found near the top of a shore phase of the Green River formation in the NW. $1 / 4$ SE. $1 / 4$ sec. 26, T. 4 N., R. 96 W., Moffat County, Colo. (See pl. 40, A.) It rests upon a thin layer of ellipsoidal algal heads, which in turn rests upon a massive bed of light-gray clean mediumgrained sandstone that is about 5.2 meters (17 feet) thick. This sandstone bed, together with two others below, makes a conspicuous cliff about 15 meters 
(50 feet) high which is chiefly light gray but is locally banded with pink, mauve, and ocher. At approximately the same horizon and only 4 miles farther west, in the NE. $1 / 4$ SE. $1 / 4$ sec. 30, T. 4 N., R. 96 W., Moffat County, Colo., is another algae reef with very sharply defined pits. (See pl. 38, B.) This may have been formed contemporaneously with the reef in sec. 26 but is not a westward continuation. It is about 1.5 meters (5 feet) thick, but only the upper third is pitted, the lower part having smooth-surfaced shells. Soft shaly sandstone and siltstone underlie this reef, and fine-grained soft light-gray to buff sandstone overlies it.

Two other pitted reefs were found in the basal unit of the formation along the road from Fruita to Rangely, near the divide between Douglas and East Salt Creeks, Colo. One which is 51.6 meters (170 feet) above the base of the formation is only 5 centimeters thick and forms heads 7 to 15 centimeters in diameter. It rests upon ostracode limestone and is overlain by finely laminated dark-brown waxy shale, which contains some ostracodes and numerous small fishbone fragments and the skeletons of small fish. The other pitted reef is 162 meters (535 feet) above the base and ranges in thickness from 0.3 to 1 meter ( 1 to 3 feet). It forms hemispherical or puffball-shaped heads 15 to 60 centimeters in diameter and makes up a part of a compound algae reef 5.5 meters (18 feet) thick. (See pl. 29, A.)

A Chlorellopsis reef which is without pits but which in configuration and internal structure closely resembles the pitted reefs was found near the base of the formation in the SE. $1 / 4$ NE. $1 / 4$ sec. 18 , T. 3 N., R. 95 W., Moffat County, Colo. It consists of much flattened cushion-shaped heads from 5 to about 20 centimeters in diameter, whose surfaces are smooth or only weakly faveolate, and is associated with regularly bedded ostracode limestone, oolite, sandstone, and shale. Each head of the reef is built up of many layers of Chlorellopsis coloniata separated by very thin layers of dense calcite. Thus the algal colonies are very extensive, some having areas of more than 1,000 square centimeters. Most of them are less than 5 millimeters thick, and none are more than 7 millimeters thick. Some consist of a single even layer of cells, but most of them are many cells deep and are minutely mammillate.

These colonies illustrate well the effect of contemporaneous accumulation of small amounts of detrital material and also indicate that the cells of Chlorellopsis coloniata were invested in a gelationus integument. Several algal layers, otherwise almost perfectly smooth, are deeply indented by pockets filled with subangular limestone pellets, fine sand, oolite grains, and ostracode valves. Some of the largest limestone fragments, about 4 millimeters long, stand with their major axes nearly vertical and their lower ends resting in sharp downfolds of algal colonies. (See pl. 40,B.) Evi- dently the investing medium of the algal cells was tough enough to bend sharply without breaking.

\section{REEFS OF RECUMBENT COLONIES}

Large recumbent Chlorellopsis colonies form reefs of closely appressed spheroidal.heads which are 6 to 8 centimeters thick and 12 to 20 centimeters in diameter. Locally these heads have the form of short roundtopped columns as much as 30 centimeters high. Moderately soft light chocolate-brown shale which weathers mouse-color underlies and overlies these reefs. The upper surface of each head bears closely spaced irregular cushion-shaped protuberances 0.5 to 3 centimeters in diameter and about 0.5 centimeter high. The sides have peripherial wrinkles or folds that vaguely resemble fabric, and the bottoms are practically smooth. A vertical section through a head shows that the deposit is built up of large recumbent colonies of Chlorellopsis coloniata. (See pl. 41, A.) These are exceedingly irregular, but most of them are discoid layers which range from about 1 to 6 centimeters in diameter. They average about 0.5 centimeter in thickness, but a few are as thick as 1 centimeter. Their eccentric growth lines are convex in the direction of the radii of the colonies except in those colonies that form the surface layer, in which the growth lamellae are convex upward. Most of the colonies are separated by very thin, mildly brecciated layers of light-buff dense calcite. Between some of them are thin irregular layers and lenses of contorted chocolate-brown shale similar to that upon which the reef rests.

Thin sections of these colonies show that many of the Chlorellopsis cells are ellipsoidal but apparently only because they are so densely packed. The cells are embedded in a microgranular matrix of calcite which was originally rather porous. Secondary quartz in small interlocking grains now fills the pores. Also the thin sections show that the thin buff layers consist of transversely arranged calcite crystals and that the brown shale contains enough organic matter to be regarded as a low-grade oil shale.

Why the algae in these reefs formed such unusual colonies is not wholly clear. So decided a tendency toward the formation of discoid colonies by peripheral growth seems to indicate that free vertical growth was inhibited. The inhibition may have been due to the deposition of a thin film of organic ooze or the precipitation of a thin layer of calcium carbonate on the upper surfaces of the colonies. Perhaps also the overlapping of contemporaneous colonies prevented upward growth. On the other hand, the mildly brecciated limy layers, together with the gently contorted organic shale, suggest that the basement yielded under the weight of the growing colonies so that they were unable to assume their normal cushion or puffball shape. A somewhat higher concentration of dissolved salts in the lake water of that stage might also have in part caused the 
peculiar habit of the algae in these reefs. They are associated with beds of sun-cracked shale and at least one bed of rather low-grade oil shale which contains many small calcite pseudomorphs after glauberite. Although the salinity of the water might have increased enough to modify the habit of the plants, the supposed change was probably not great, for the form and size of the cells remained unchanged. The bulbous colonies of the surface layer indicate more normal conditions of growth and also serve to demonstrate that the recumbent habit is not a character upon which to found another species of Chlorellopsis.

These algae reefs were obviously formed in quiet water, but at what depth it is impossible to say except that it must have been shallow enough to promote active photosynthesis in the algae. They were found at the base of the saline facies of the Green River formation in the composite section measured in Indian Canyon along the mail road from Duchesne to Price, approximately in sec. 28, T. 6 S., R. $7 \mathrm{~W}$. Uinta meridian, Duchesne County, Utah. One reef is about 1,063 meters (3,830 feet) and the other about 1,185 meters $(3,900$ feet) above the base of the formation.

A thin partly silicified reef consisting of a few layers of recumbent Chlorellopsis coloniata colonies was found in the basal tongue of the Green River formation just north of Soldier Summit, Utah County, Utah. These colonies range in diameter from 0.5 to about 4 centimeters, but very few exceed 3 millimeters. They rest either upon a very uneven substratum apparently made up of heaps of plant detritus mixed with ostracodes and mollusk shells or upon thin irregular zones of spongy algal deposit whose interspaces have been filled with chalcedonic silica. Some of the Chlorellopsis molds are filled with silica, others with yellowish microcrystalline calcite. In the partly silicified débris which the algae incrusted were found large pieces of the tissues of higher plants, cuticles of leaves, various pollen grains, and numerous short fungal hyphae, some of which bear simple terminal conidia. Thin and somewhat contorted layers of yellowish-brown limy shale are also included in the deposit. Stems of Chara, but no fruits, are fairly plentiful in a silicified layer associated with the algae reef. Clearly this reef formed in quiet water, which was probably'also shallow and close to a protected shore.

\section{REEFS WITH SPONGY STRUCTURE DIGITATE REEFS}

A specimen representing an unusual type of reef occurs either as isolated spheroidal or potato-shaped heads or as large botryoidal intergrowths of these forms and is embedded in light-brown flaky or platy sandy shale whose bedding is somewhat contorted. (See pl. $41, B$.) It is overlain by a bed of massive hard greenish-gray shale that contains many secondary gypsum partings. The upper surface bears many irregular mound or ridge shaped excrescences separated by rather deep depressions, which are partly filled with buff limy mudstone. In addition to these larger features the upper and lower surfaces are vigorously tuberculate or papillate. The steep sides are granular or pustulate. In its form and sculpturing it resembles closely a specimen of Lithothamnium? ellisianum described by Howe and Goldman. ${ }^{29}$

A polished vertical section of this specimen, however, shows that the heads of the reef consist of many digitate groups of interrupted cuneiform lobes of finely crystalline calcite which show fine arcuate growth lines delicately colored in tints that range from deep reddish brown to buff. (See pl. 42, B.) Very fine grained dark bluish-gray to cream-colored limy sandstone fills compactly the spaces between the calcite lobes or columns. Clear crystalline calcite fills some of the cavities that were apparently not open enough to permit the sand to enter.

A transverse section of this specimen shows that the lobes or columns are arranged in a roughly concentric manner and that although they are exceedingly irregular in cross section they show a marked tendency toward centrifugal thickening, especially in those near the periphery. (See pl. 42,A.) The smaller columns are simple and nearly circular in cross section, but the larger ones are deeply and complexly embayed.

The internal structure of this reef resembles rather closely an algal deposit from the north German Buntsandstein at Schlossenberg described by $\mathrm{Kal}-$ kowsky..$^{30}$ It also resembles the algae reefs now being formed in Green Lake, N. Y.

Thin sections cut parallel to the columns reveal in them obscure algal forms. The plainest of these are several transverse zones of Chlorellopsis coloniata molds. Other parts of the columns or algal colonies consist mostly of microcrystalline calcite which locally has a spongy structure resembling that of certain recent algae reefs, but there are also areas of uniformly fine granular calcite that shows no other structure than vague growth layers. The obscurity of the plant structure in this specimen seems to be due chiefly to lack of differentiation in size of crystal grain between the plant molds or casts and the matrix.

This reef is peculiar not only in its complex, digitate habit of growth but also in its content and distribution of organic matter and limonite grains. Each algal colony and branch has just beneath its surface a thin layer of closely packed fine limonite granules, many of which are cubical. Locally the granules are also scattered sparsely through the interior of a colony. Associated with the limonite or distributed in skeleton

${ }^{29}$ Howe, M. A., and Goldman, M. I., Lithothamnium? ellisianum, sp. nov., from the Jurassic Ellis formation of Montana: Am. Jour. Sci., 5th ser., vol. 10, p. $316,1925$.

30 Kalkowsky, Ernst, Oolith und Stromatolith in norddeutschen Buntsandstein: Deutsche geol. Gesell. Zeitschr., vol. 60, pp. 106-107, pl. 8, 1908. 
forms of tall algal colonies within the limonite encasements is a considerable quantity of yellowish-brown organic matter. It is not homogeneous, but neither does it contain identifiable organisms. It resembles the organic matter of oil shale and is still further analogous to such matter because it is diffused through microgranular calcite. This reef derives its colors from the limonite and organic matter.

Apparently the limonite is secondary after pyrite that formed from decomposition products of the organic matter and iron salts dissolved in the lake water. Moreover, the organic matter is probably a residuum of the plants that built the reef, not only because it has the form of algal colonies but also because the deposition of an organic ooze upon the reef would hardly be expected in water continually transporting and depositing sand. Furthermore, the segregation of the limonite close to the peripheries of colonies suggests that the inclosed algae subsequently decayed and that as hydrogen sulphide from their decay migrated outward it precipitated pyrite where it came into contact with iron salts in the lake water. The occurrence of disseminated limonite granules within some colonies is also in harmony with this hypothesis.

This particular specimen shows two major stages in the history of the reef's development. At $a$, Plate 42, $B$, is an irregular nucleus of dense cream-colored calcite from which finely laminate colonies radiate. $A$ buff band, shown in white in the photograph, circumscribes the nucleus and passes through the tips of the colonies that radiate from it. The colonies directed downward from the nucleus are much longer than those directed upward. Because they grew principally upward by accretion of calcite at their tips it is evident that the part of the reef circumscribed by the buff band was overturned when it had reached that stage of its development. A similar but less striking nodule cut so as to just miss the nucleus may be seen to the right of this one. (See pl. 42, B.) There are also small short colonies on what was the under side of the larger nodule. Whether these grew downward where the nodule did not actually rest on the bottom it is difficult to say. The absence of them on the originally lower side of the smaller nodule lends slight support to this idea.

The second stage in the developmental history of this specimen is represented by the tall flabellate colonies that make up the larger part of the specimen. They are oriented as they grew. (See pl. 42, B.)

This reef is so similar to those now being formed in Green Lake, N. Y., that it seems safe to infer for it a like origin. The tall flabellate and complexly branched protuberances whose tips are richly nodose are remarkably like those of the recent reefs and like them were probably formed through the agency of a dense felt of algae. The elongated protuberances of the recent deposits seem to be due to rapid growth and a struggle of the plants to acquire better illumination. Similar features in the fossil reefs seem properly to be explained in the same way. The overturning of these nodules when partly formed indicates at least periodic strong wave action, and the abundance of fine, well-sorted sand between the arborescent masses also indicates current or wave action. From these the writer concludes that this reef was formed in fairly shallow water.

This reef was found approximately in sec. 22, $\mathrm{T}$. 10 S., R. 25 E., Uintah County, Utah, about 82 meters (270 feet) above the base of the Green River formation.

\section{TABULATE REEFS}

Tabulate reefs of essentially uniform thickness occur within beds of fine-grained and somewhat shaly oolite, which also contains numerous ostracodes. (See pl. 43, B.) At one locality a reef of this kind contains vertical molds of large deeply fluted Equisetum stems. The top consists of slightly arched, very irregular, and more or less closely appressed molariform or reniform protuberances, which are yellowish buff. Small oolite grains in a dense gray matrix occupy most of the depressions between these. The lower surface of the reef is practically flat.

As shown in the polished cross section the reef is built up of many rather thick layers of porous yellowish-gray calcite. These layers are only slightly sinuous near the base but become more and more irregular toward the top, where they form a series of flat-topped, steep-sided arches separated by deep channel-like depressions that are partly filled with fine oolite grains cemented by light-gray calcite: Such deep crooked channels give the cross section of the reef a crudely columnar aspect.

Vertical thin sections of a reef of this type show that the rather poorly defined layers consist of microcrystalline calcite and have a spongy structure. The microcrystalline calcite contains thin branching lines of slightly coarser grained calcite which have a prevailing radial habit. (See pl. 34, B.) Some of these may be the casts of filamentous algæ, but others clearly are not, for they fork downward as well as upward and form a continous network between the irregular microcrystalline masses. Furthermore they are not at all uniform and widen into comparatively large cavities, which differ greatly in size and have no definite form. These coarser-grained calcite lines seen rather to be cross sections of thin secondary fillings between the microcrystalline calcite masses. Moreover, thin sections cut normal to these fine radial lines that most resemble algae support this hypothesis, for none of them are circular or even elliptical in cross section. They entirely surround the transverse sections of columnar and globular microcrystalline masses that make up the reef. 
The spongy but otherwise structureless aggregate of microcrystalline calcite is exactly comparable to the deposits of calcium carbonate localized by members of the Cyanophyceae at the present time in fresh-water lakes, and very probably it had a similar origin. Small calcite oolite grains which apparently formed where they are now found are associated with reefs of this kind and indicate that the water, for a time at least, was saturated with respect to calcium carbonate. Vertical molds of large Equisetum stems occur in one reef. These evidently grew contemporaneously with the reef and show that the deposit formed in very shallow lake margins, where a more or less sparse emergent vegetation prevented not only strong water movements but also the influx of much clastic material. Although shallow, the water was probably clear except at times of storm, when the limy mud was thrown into suspension. Such shallow and slow-moving water must also have been considerably warmed, a condition favoring the formation of the oolitic marl in which this type of reef occurs.

One reef of this kind was found at the base of the Laney shale member of the Green River formation in the NW. $1 / 4$ sec. 18, T. 25 N., R. 103 W., Sweetwater County, Wyo. A similar reef occurs in Colorado near the top of the basal unit of the formation, about 161 meters ( 530 feet) above the base, on the divide between East Salt and Douglas Creeks a few hundred feet east of the saddle through which the Fruita-Rangely road passes. This land has not been sectionized, but the locality is approximately where sec. 13, T. $5 \mathrm{~S}$., R. 102 W., would fall.

\section{COMPOUND REEFS}

Reefs built up of more than one principal structural type have been grouped for convenience of exposition under the general term compound reefs. They may include not only Chlorellopsis colonies, Confervites filaments, and the less definite masses with spongy structure but also physico-chemical incrustations.

\section{REEFS CHIEFLY ALGAL}

Compound reefs that are chiefly algal were found in beds of limy shale as isolated, more or less widely spaced low circular heads that are somewhat biscuit or mushroom shaped, 3 to 8 centimeters high, and 5 to 18 centimeters in diameter. The upper surface and sides consist of a mosaic of smaller heads, which are irregularly rounded or elliptical but somewhat flattened or even concave on sides where they are closely appressed. Although the upper surface was worn nearly smooth by scour before burial, each minor head was originally bulbous and represents an individual algal colony. (See pl. 44, B.) Along the margins where abrasion wás less these are now wartlike protuberances. The under surface has the form of an inverted irregular basin with a nearly flat bottom and steep or even. overhanging sides.

A polished cross section of a specimen representing this type reveals four growth zones, each with a distinct structure. (See pl. 44, A.) The lowest zone has a spongy structure and consists of dense brownish-gray calcite. The interspaces are completely filled with clear coarsely crystalline calcite, which is evidently secondary. The second zone is considerably thinner and consists of dense calcite finely color banded in shades of red-brown, yellow, and gray. This zone is more compact than the others and closely resembles. agate. Overlying the agate-like zone is a layer which has a spongy structure somewhat similar to that of the basal layer except that the areas of dense calcite are larger and light buff. In places they are radially elongated and give the zone a very crude columnar structure. Many of the elongated pieces are distinctly arborescent. Some of the interspaces of thin layers have been filled with clear calcite, but most of them are still open. The structure of both spongy zones is very much like the internal structure of the algae reefs now being formed in Green Lake, N. Y. The surface layer consists of rather large and irregular bulbous or puffball-shaped colonies of Chlorellopsis coloniata Reis, which rise from a nearly continuous substratum of the same organisms. (See pl. 44,A.) These colonies are about 1 centimeter high and range in diameter from 4 millimeters to 1.7 centimeters. Some are irregular sprawling forms, and a few are forked near the summit, but most of them are simple. All contain thin irregular stringers or clavate lobes of dense buff calcite in which the plant cells occur only sparingly.

Areas between the algal colonies are filled with dense brownish calcite that shows fine laminae outlining the colonies. Between some colonies are pockets of fine sand mixed with a few small ostracode valves.

Under the microscope the two spongy layers separated by the agate-like zone appear to be identical except only that more interstices of the lower one contain coarsely crystalline secondary calcite. The irregular and somewhat arborescent masses that make up these layers consist of even-grained microcrystalline calcite, which locally contains a few fine interlacing lines of more coarsely crystalline calcite that may may be the casts of filamentous algae. The agatelike layers consist mostly of tiers of radially elongated calcite crystals, but locally the whole zone is made up of finely granular calcite. Minute granules of limonite are scattered through this zone or are arranged in definite layers. These layers, perhaps together with small quantities of organic matter, give to the zone its banded aspect and various shades of red, brown, and gray. Many of the limonite granules are cubical, and probably all are secondary after pyrite. In the micro- 


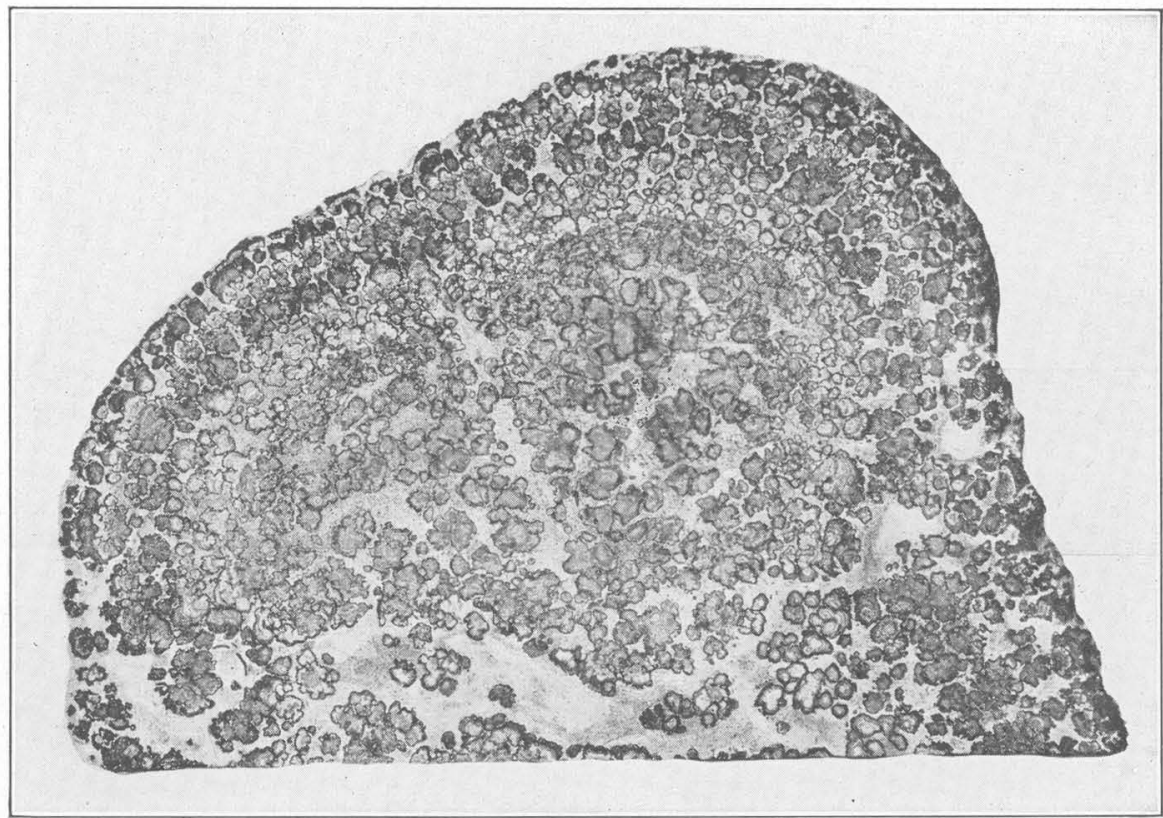

A. POLISHED TRANSVERSE SECTION OF THE DIGITATE REEF SHOWN IN $B$ Natural size

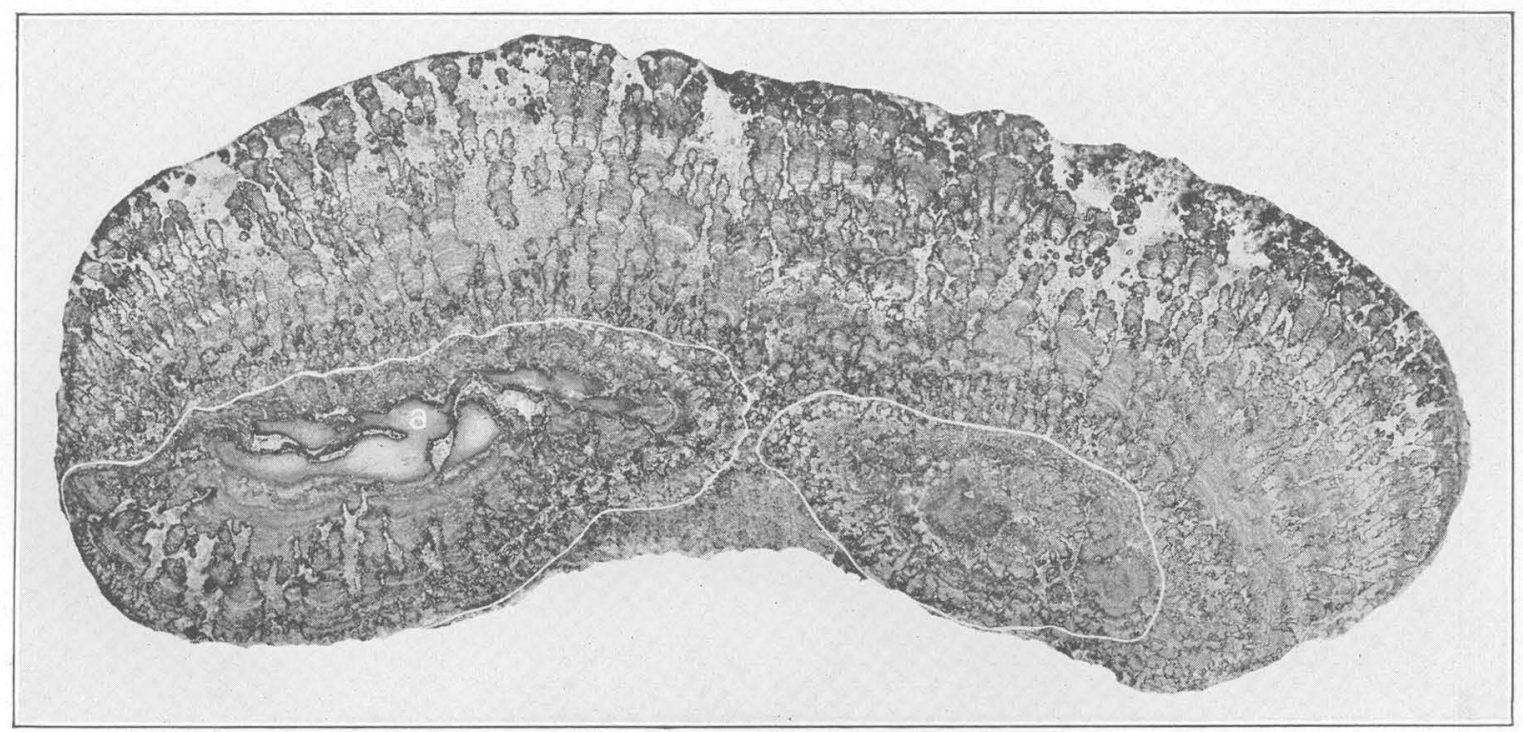

B. POLISHED VERTical SECTiON OF A Digitate AlgaE REEF

Showing nuclei of dense cream-colored limestone (a) and two distinct stages of growth. The light-gray finely speckled material between the columns of algal deposit is fine-grained limy sandstone. Natural size 


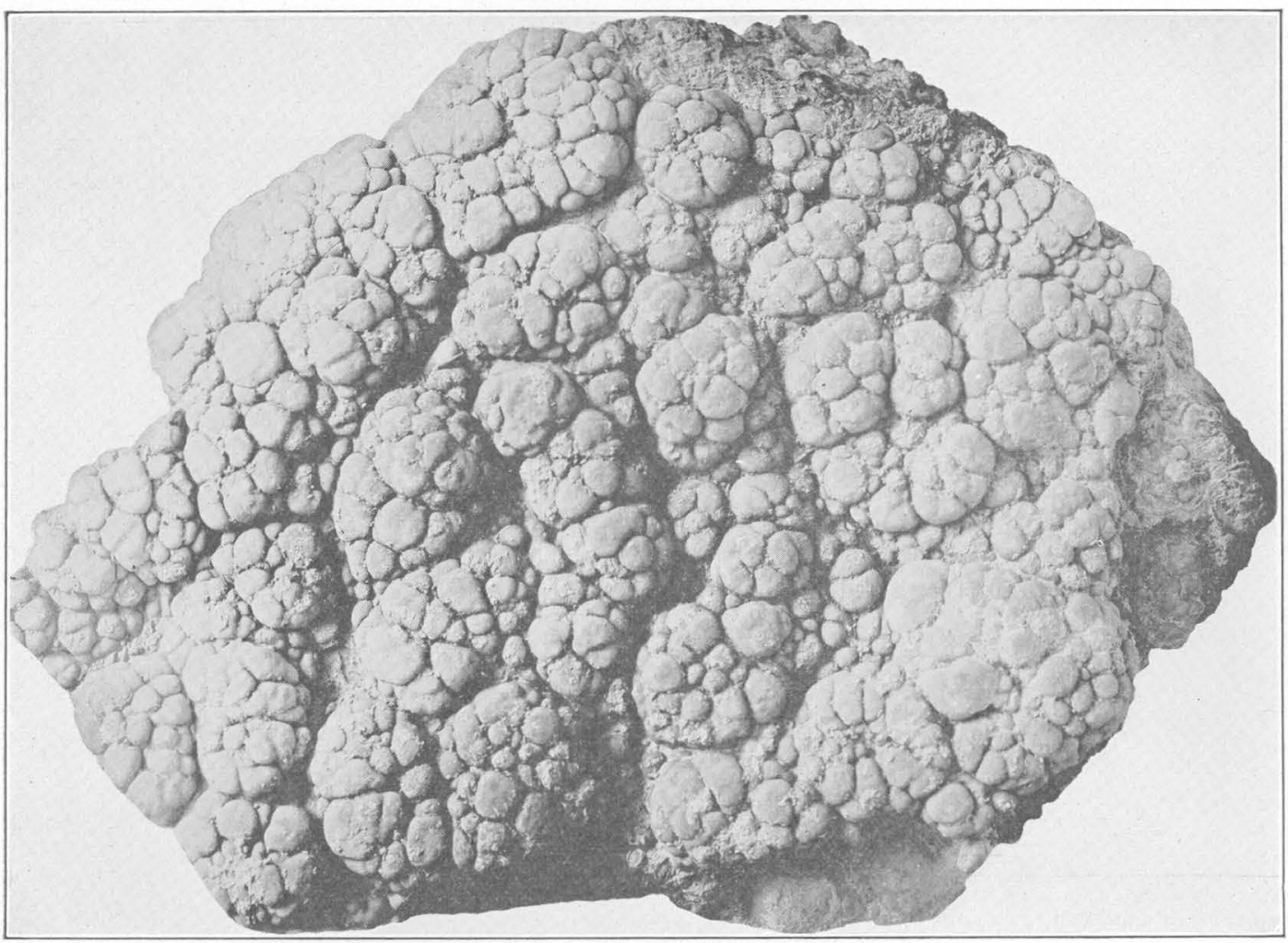

A. UPPER SURFACE OF A COMPOUND REEF WHICH CONSISTS OF ALTERNATING ZONES OF ALGAL AND INORGANIC LIMESTONE

Near base of Tipton tongue of Green River formation in NW. 1/4 sec. 21, T. 24 N.. R. 101 W., Sweetwater County, Wyo. Threefourths natural size

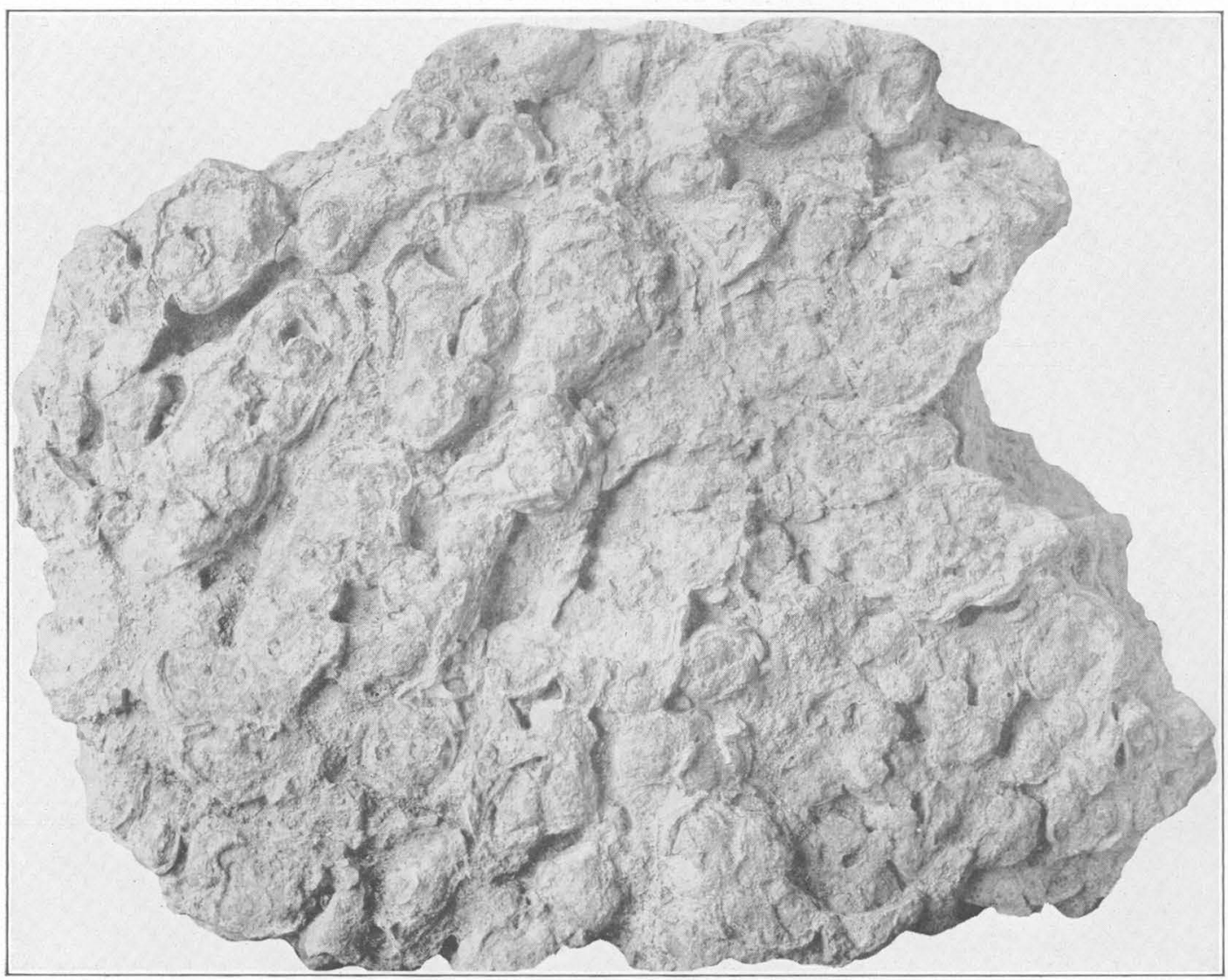

B. UPPER SURFACE OF A TABELLATE REEF WITH SPONGY STRUCTURE

Each molariform head is more or less columnar in section, though many of them are very irregular and complexly intergrown. Three-fourths natural size 


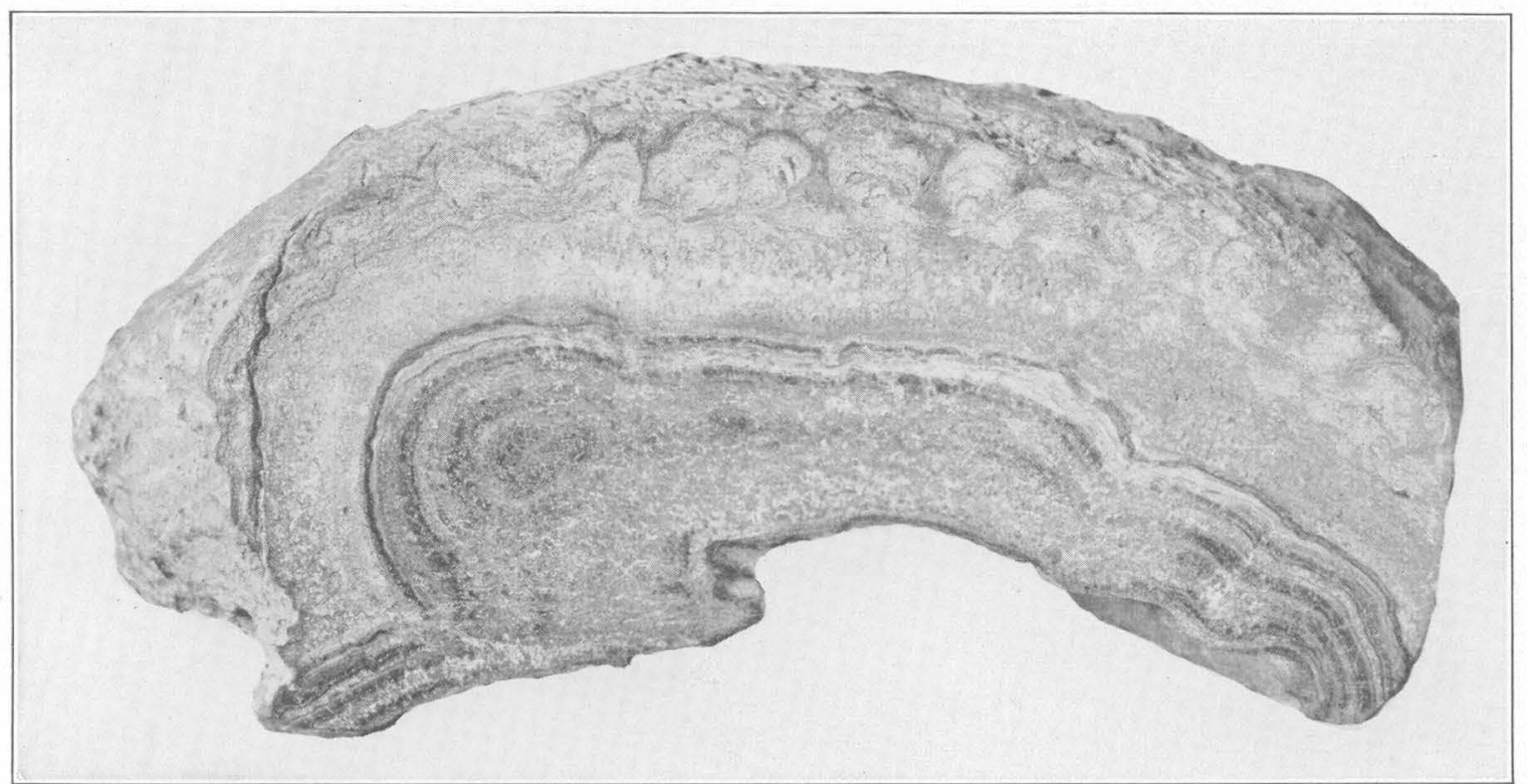

A. POLISHED VERTICAL SECTION OF A COMPOUND ALGAL HEAD CONSISTING OF MANY SMALL HEADS, EACH OF WHICH REPRESENTS A SINGLE COLONY OF CHLORELLOPSIS COLONIATA REIS

These minor heads rest upon a zone of spongy algal deposit, which is separated from another similar zone below by a finely banded inorganic agatelike zone. Natural size

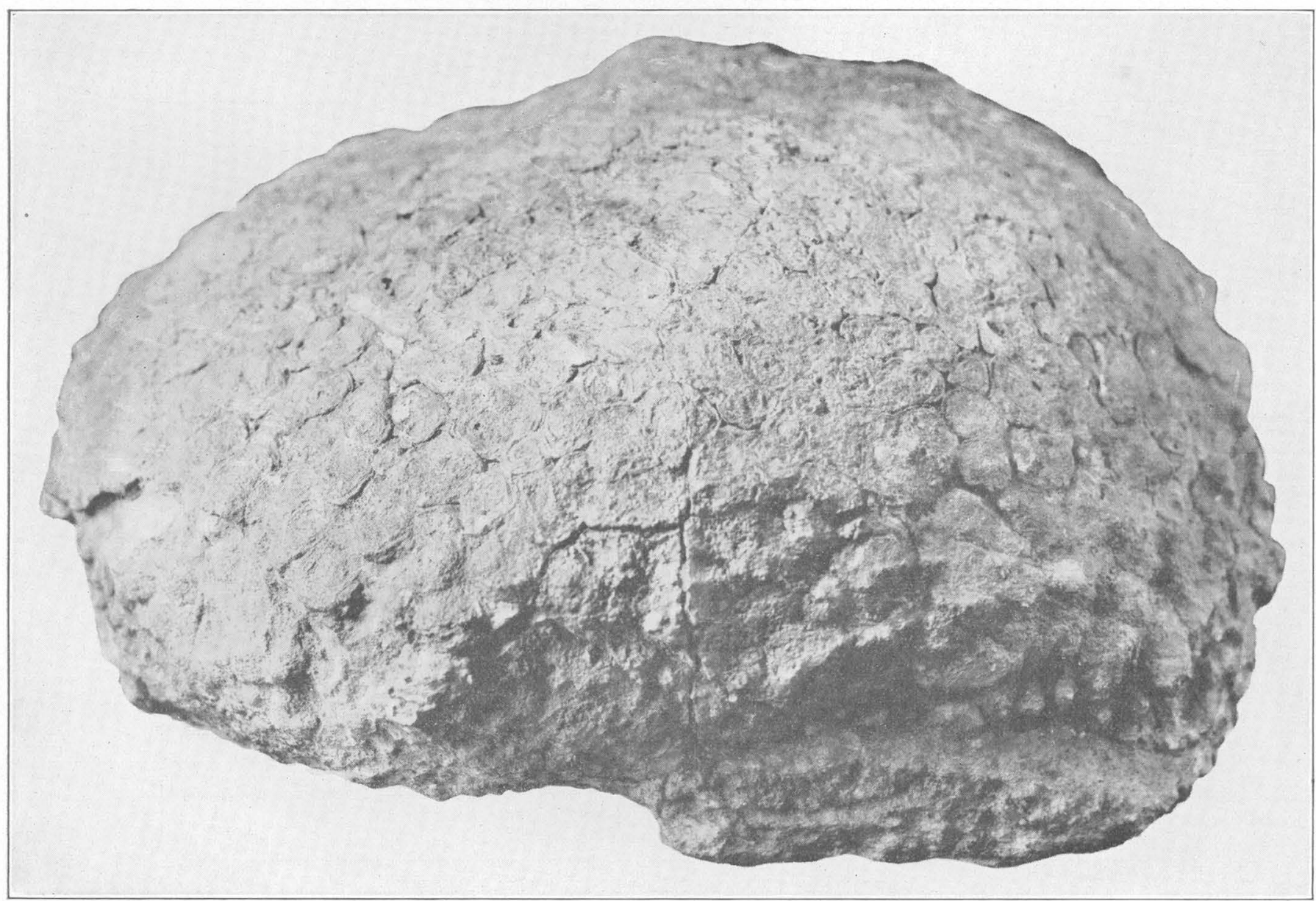

B. COMPOUND ALGAL HEAD CONSISTING OF MANY MINOR HEADS, EACH OF WHICH REPRESENTS A SINGLE COLONY OF ALGAE Compare with $A$ 


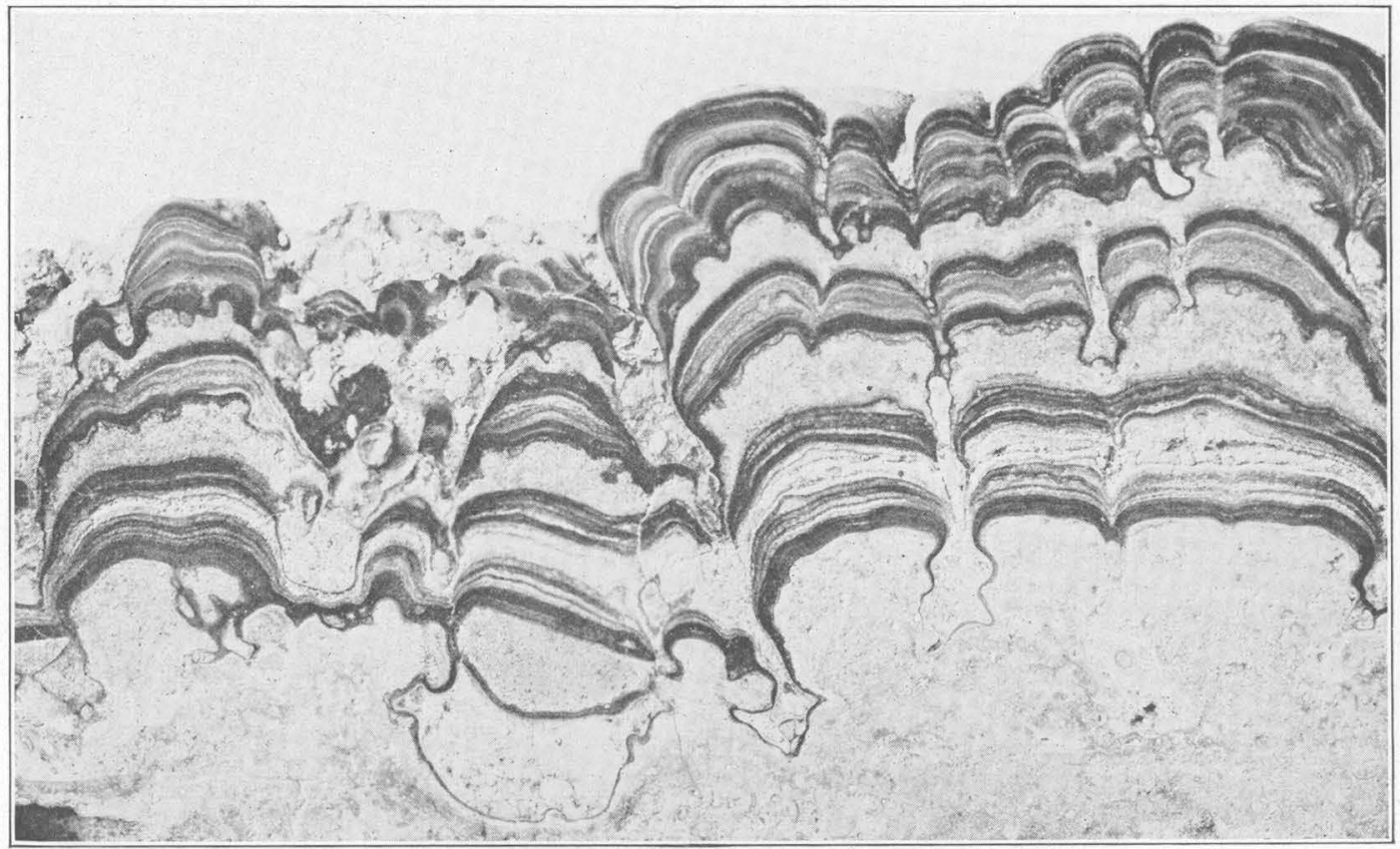

A. POLISHED TRANSVERSE SECTION OF THE REEF SHOWN IN PLATE $43, A$, SHOWING ALTERNATE ALGAL AND INORGANIC LAYERS

The irregular light-colored layers consist of the molds of Chlorellopsis coloniata and typical spongy algal deposit. The black and gray finely banded layers are of inorganic origin and owe their dark color to disseminated pyrite. Enlarged 3 diameters.

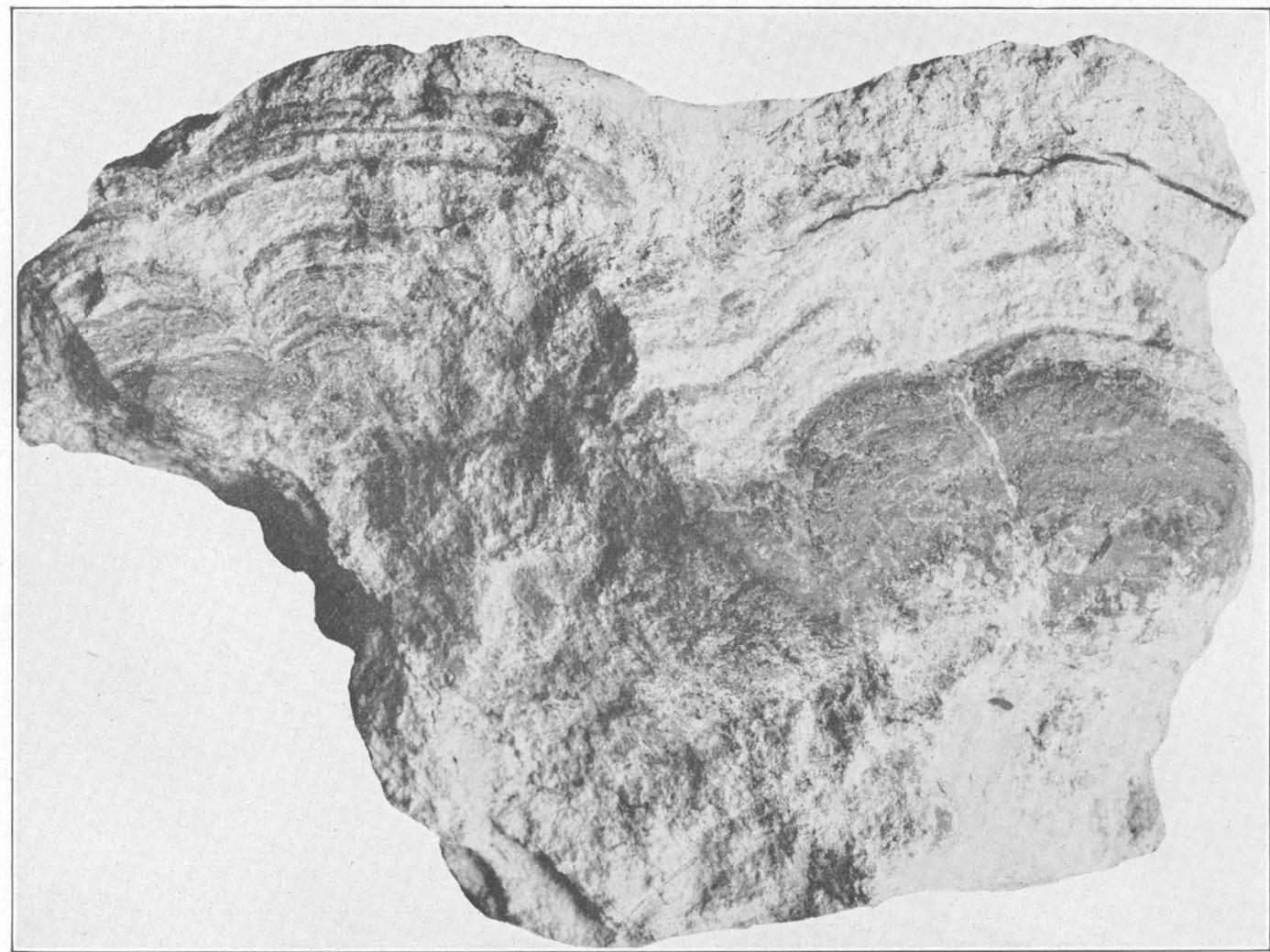

B. ALGAE REEF FROM THE "MANTI BEDS," MANTI, UTAH

The dark areas are partly silicified and contain the filamentous algae and coprolites shown in Plate 33 . Natural size 
U. S. GEOLOGICAL SURVEY

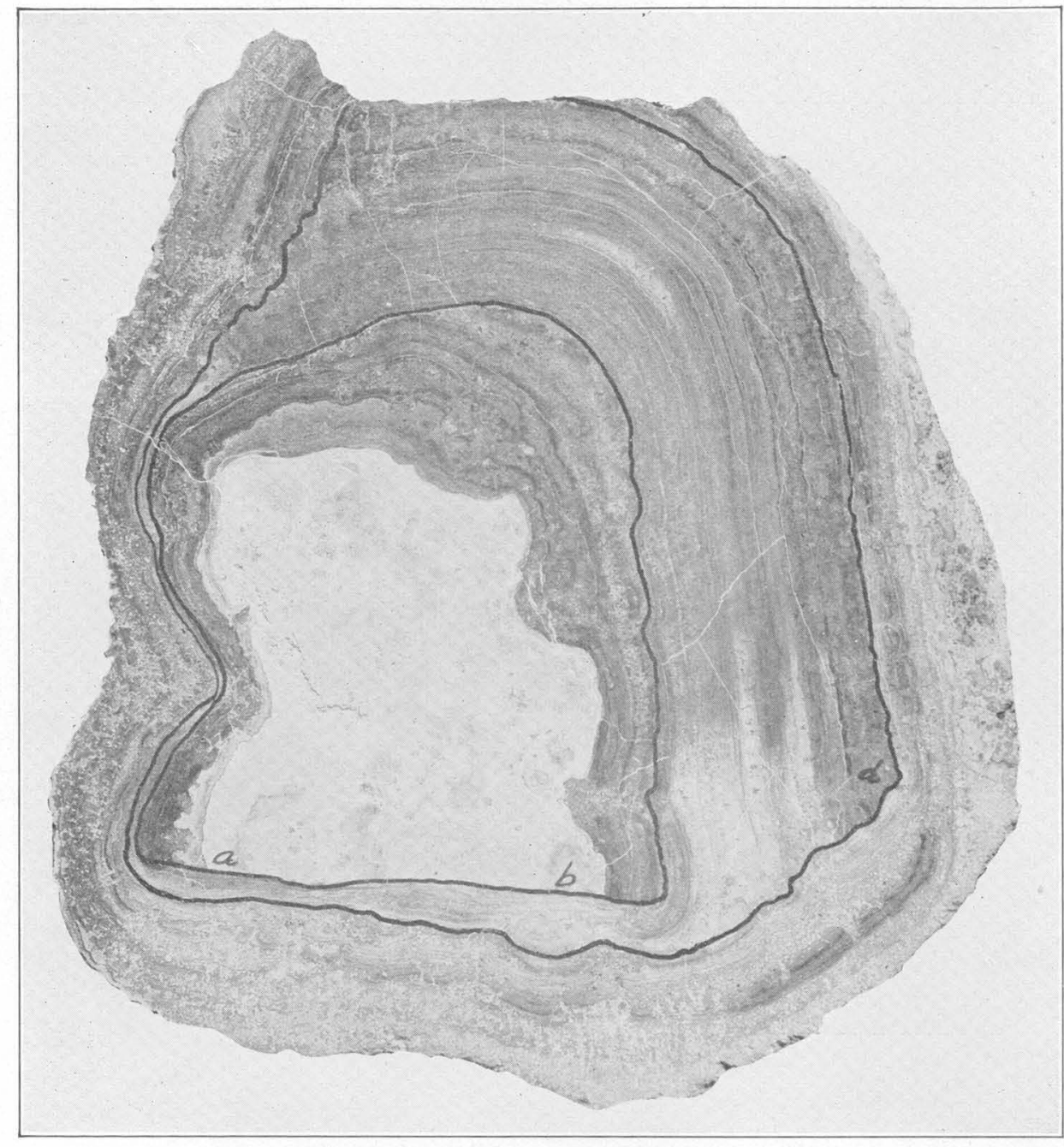

A. POLISHED SECTION OF AN ALGAL COBBLE

Showing a large subangular limestone nucleus and three distinct stages of growth. Natural size. See text, p. 219, for explanation of letters

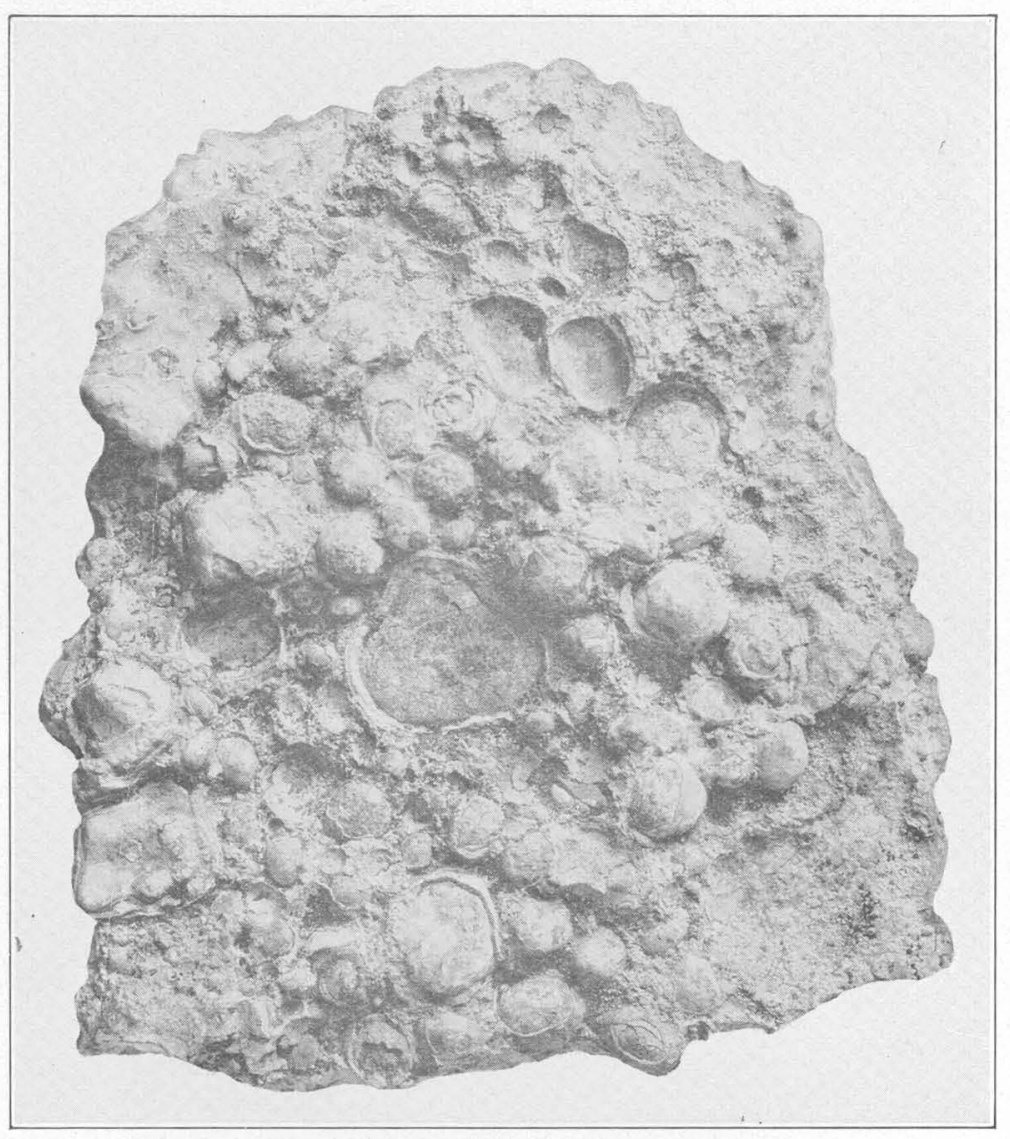

B. ALGAL PEBBLES FOR MED CHIEFLY OF CHLORELLOPSIS COLONIATA REIS IN A MATRIX OF OSTRACODE LIMESTONE Natural size 


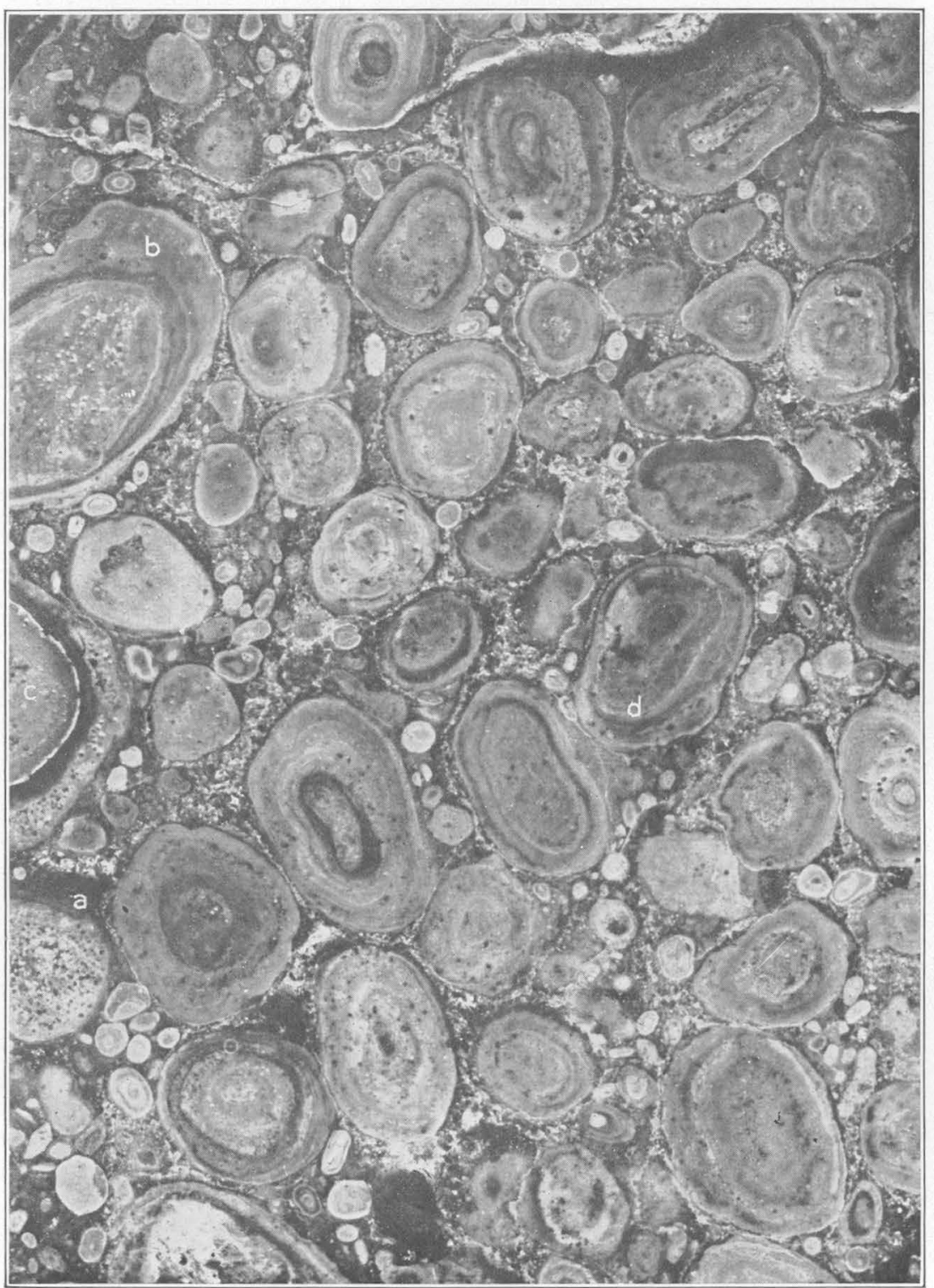

POLISHED SPECIMEN OF ALGAL PEBBLES SHOWING DETAILS OF INTERNAL STRUCTURE

At a is a pebble consisting wholly of Chlorellopsis coloniata, at b and c are pebbles made up chiefly of

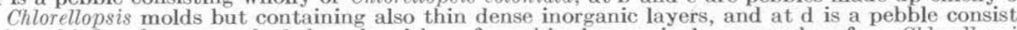
ing chiefly of spongy algal deposit with a few thin inorganic layers and a few Chlorellopsis
molds. Between the algal pebbles are small oolite grains mixed with fine limy sand. Enlarged 5 diameters 


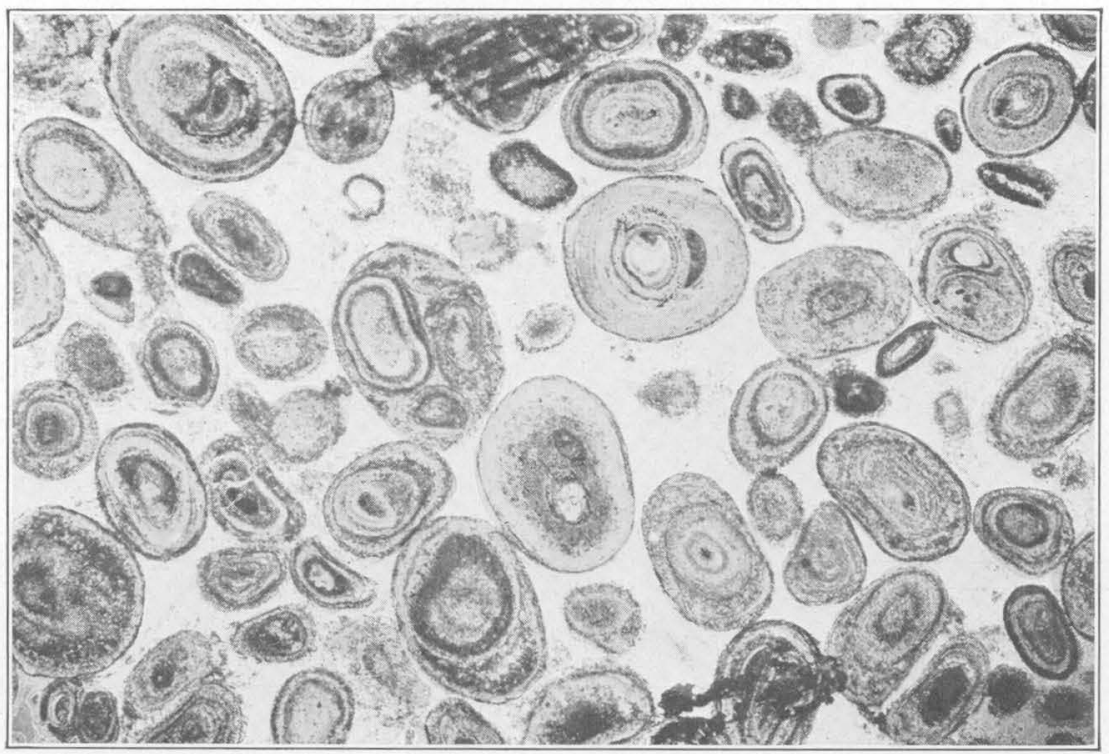

A. THIN SECTION OF AN OOLITE FROM THE LANEY SHALE MEMBER OF THE GREEN RIVER FORMATION ON SHELL CREEK, SEC. 9, T. 12 N., R. 98 W., WYO.

Showing large oolite grains with eccentric growth zones. The darker granulose parts of these grains consist of mechanically enmeshed silt, and the clearer parts consist of fine-grained calcite partly
replaced by chalcedonic silica. The groundmass consists of chalcedonic silica, with scattered microcrystals of calcite. Enlarged $11 \frac{1}{2}$ diameters

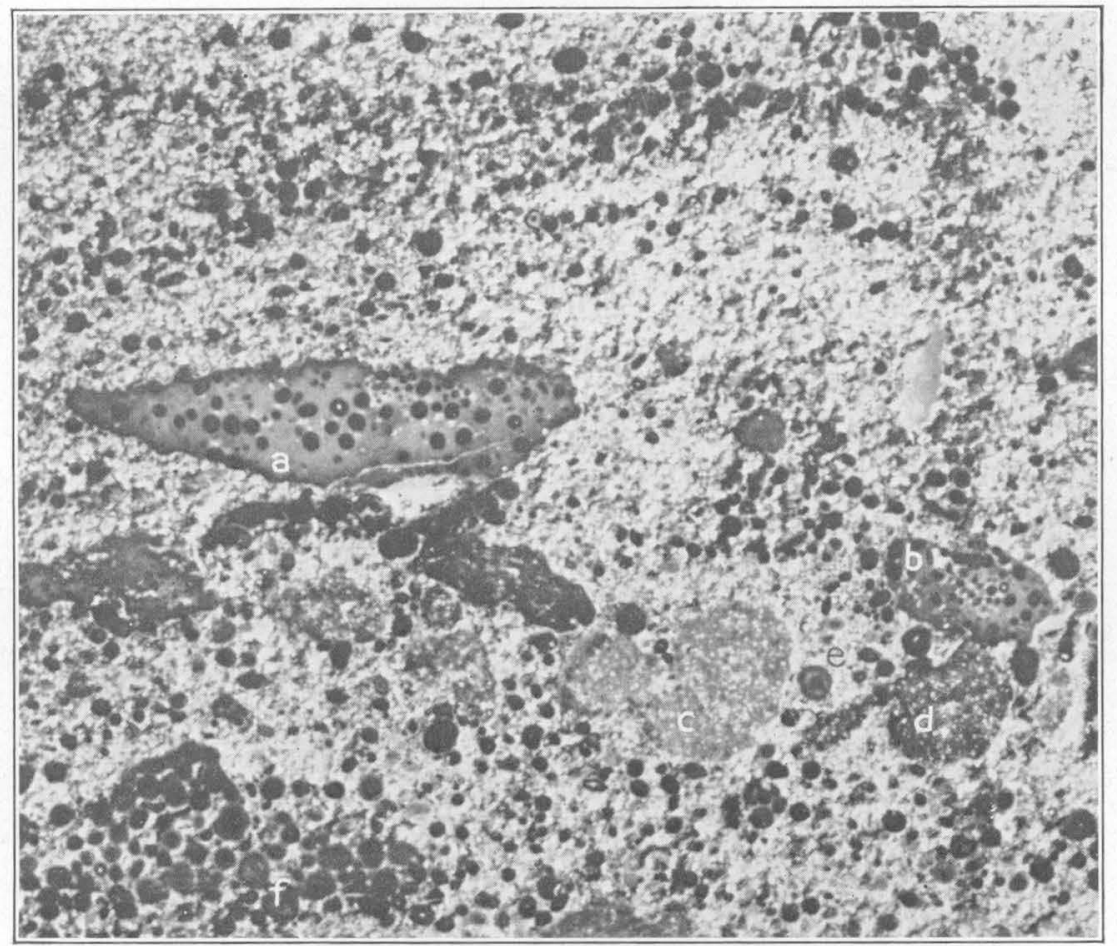

B. SMALL AREA OF THE POLISHED SPECIMEN SHOWN IN PLATE 35

This shows a part of the oolitic sandstone which contains at a and b fragments of microcrystalline calcite with ferruginous oolite grains suspended in the positions in which they formed, at $c$ and large oolite grains that show the wide concentric banding characteristic of all the oolites in this bed. Enlarged 5 diameters 
crystalline calcite between the cells of some Chlorellopsis colonies are calcite casts of small filaments in fascicular groups. These resemble somewhat Confervites mantiensis but are not well enough preserved to be worth description.

This reef evidently had four distinct stages of growth, the first and third probably by means of filamentous algae which left only vague traces of themselves. The paucity of small angular grains of feldspar and quartz and the absence of limy mudstone in these two zones indicate that they were probably formed in quiet and also clear water. The agate-like layers between them are probably of inorganic origin, and the abundance of limonite grains, secondary after pyrite, suggests that decaying organic matter through its evolution of ammonia brought about their precipitation.

Chlorellopsis and probably also some filamentous algne formed the surface layer. During this stage the water was apparently more active and deposited some fine sand in pockets between the algal colonies. Small quantities of calcium carbonate in the form of mud were also deposited on and between the colonies during their growth.

The strongly abraded surface of the reef shows that after its complete solidification it was subjected to a rather potent scouring. It is not clear whether during that erosion it was exposed to the weather.

This reef was found in the lower part of the Tipton tongue of the Green River formation in the NE. 1/4 NE. $1 / 4$ sec. 16, T. 24 N., R.' 102 W., Sweetwater County, Wyo.

\section{REEFS LARGELY INORGANIC}

A thin discontinuous reef which is representative of a small class of similar deposits that are largely inorganic (see pls. $34, C ; 43, A ; 45, A$ ) rests on ostracode limestone which contains limestone pebbles as much as 1 centimeter in diameter. In places the same bed contains small but distinct mud curls. A somewhat similar pebble conglomerate overlies the reef, but in addition to limestone fragments it contains wellrounded quartz, chert, and feldspar pebbles, some of which are nearly 1 centimeter in diameter, and also larger sharply angular fragments of a similar reef.

The reef itself is about 3 centimeters thick and makes an essentially continuous bed. The upper surface consists of somewhat flattened hemispherical heads of closely spaced wartlike protuberances, which resemble in shape, color, and even texture the thickened pads on the under side of a cat's paw. (See pl. 43, A.) The under surface is flat.

A polished cross section of the specimen shows that it consists of alternating black, dark grayish-buff, and light-buff complexly crenulated layers. The lowest buff byer has a flat base, but on its upper sides it bears relatively large, vigorously nodose flabellate or in places even arborescent Chlorellopsis coloniata colonies between which are pockets filled with ostracodes and small angular pebbles of algal limestone, all of which are so thickly incrusted with lime as to resemble irregular oolite grains. These are mixed with a little fine sand and cemented by clear calcite. Upon these colonies are built the hemispherical heads of wartlike protuberances, each of which consists of several short cushion-shaped buff layers like the basal layer except that they are thinner. These are separated by zones of thin dense black or gray layers which vary in thickness from place to place but which are continuous across the specimen. It is also significant for their proper interpretation that in places the black layers line cavities, fill cracks, and follow the reentrants below overhanging buff layers. (See pl. 45, A.) Moreover, their upper surfaces, except where interrupted by detrital material, are smooth curves and contrast sharply with the richly nodose upper surfaces of the buff layers.

Between the turbinate or puffball-shaped heads are pocket-like depressions filled with detrital material such as small ostracodes, angular fragments of dense buff calcite, small sand grains, and oolite grains some of which have an ostracode valve for a nucleus. Clear calcite forms the matrix of these pocket fillings. Pyrite now partly altered to limonite has completely replaced the fillings of a few such pockets near the top of the reef.

Thin sections of this specimen show that the upper part of the basal buff layer and also the other buff layers consist of spongy microcrystalline calcite which contains a network of algoid lines of coarser-grained calcite. They were very probably deposited by a felt of algae. (See pl. 34, A.) In thin section it becomes apparent that the black or dark-gray agate-like layers have been completely recrystallized, for their long acicular calcite crystals, some of which are more than 0.1 millimeter long, cross thin layers of yellowish organic matter and thin zones of limonite granules that probably mark successive stages of peripheral growth. The layers that separate the zones of long acicular crystals consist of granular calcite with a small quantity of organic matter and an abundance of small limonite grains, many of which are cubical.

Locally the limonite grains are so closely spaced that they appear as black bands, even though highly magnified. Much of the dark color of these layers is due to them. Yet vast numbers of irregular black particles, 3 microns or less in diameter, disseminated through the calcite crystals of the fibrous layers, also contribute to the black or dark-gray tones.

Apparently this reef grew under variable conditions, being built up now by means of algae and again by physico-chemical precipitation, and each process was 
modified somewhat by the sporadic accumulation of detrital grains. Moreover, the algal and inorganic deposits alternated in a periodic fashion.

The algal deposits contain pockets and lenses of detrital material in which angular limestone pebbles 1 to 3 millimeters in length are fairly plentiful. Therefore it seems probable that the algal layers were formed in shallow water when waves and currents were more or less active. The conditions under which the black and gray agate-like layers formed are not so clear. If the black particles disseminated through their crystals are organic matter they suggest that, in periods of quiet, layers of organic ooze were deposited on the algal deposits and that ammonia generated by the decay of this ooze localized the precipitation of calcium carbonate. This hypothesis is supported to some extent by the prevalence in these dark layers of cubical limonite grains which are probably secondary after pyrite. Then too, in harmony with this suggestion there are, in the upper part of the reef, masses as much as 1 centimeter in diameter of pyrite partly altered to limonite. Nevertheless, other physicochemical factors probably also operated to precipitate calcium carbonate, for ostracode valves and small fragments of limestone within this reef are incrusted with concentrically layered fibrous calcite that is entirely free from iron oxide, organic matter, and black particles.

This reef occurs about 5.5 meters (18 feet) above the base of the Tipton tongue of the Green River formation in sec. 21, T. 24 N., R. 101 W., Sweetwater County, Wyo.

\section{REEF FROM THE "MANTI BEDS"}

A reef from the "Manti beds" (pl. 45, B) has the form of elongate lenses about 25 centimeters in maximum thickness, rests upon thin-bedded white shaly limestone, and is overlain by laminated very limy shale. Its upper surface is botryoidal.

A polished vertical section through the reef shows that it is built up of many tiers of arched and finely tuberculated layers interspersed with thicker, coarsely spongy layers. The thinner layers that resemble agate are gently sinuous or arcuate and banded in shades of yellowish and brownish gray. Several of the spongy zones are minutely punctate. The dark areas shown in Plate $45, B$, are partly silicified. This reef is unique among those of the collection because a small partly silicified area of it contains a network of the fossil filamentous alga Confervites mantiensis. (See pl. 33,C.)

Thin sections of the reef show that it consists almost wholly of microcrystalline calcite which has a spongy structure and is of algal origin. It also contains several colonies of Chlorellopsis coloniata. Further, some of the partly silicified zones consisted originally of microcrystalline calcite which shows no structure and is perhaps an inorganic deposit.
This reef is chiefly interesting for its fossil filamentous algae and the numerous coprolites that are associated with them. (See pl. 33, B.) It occurs near the top of the "Manti beds" in a quarry just east of the Mormon temple in Manti, San Pete County, Utah. The exact location is unknown, but it is approximately sec. 6 , T. 18 S., R. 3 E. Salt Lake meridian.

\section{ALGAL NODULES OR COBBLES}

The algal nodule shown in Plate 46, $A$, came from a layer of similar isolated nodules or cobbles between two beds of hard gray-green sandy clay. It is irregularly rounded and has a minutely nodose surface. A transverse section shows that it is built up of three zones of algal deposit about an irregular nucleus of dense buff ostracode limestone surrounded by masses of closely packed small ostracode shells, which are cemented in some places by clear secondary calcite and in others by gray sandy limestone.

Under the microscope this specimen shows no fossil algae, but nevertheless its microstructure is predominantly algal. The greater part of the first and third zones consists of spongy-structured microcrystalline calcite in minutely mammillate layers with many small pockets of fine-grained, sharply angular sand. The intermediate zone consists of a succession of very thin and unusually regular layers. The thicker of these consist of spongy microcrystalline calcite with a few pockets of detrital grains and are entirely similar to the deposits of the first and third zones of the specimen. But the thinner layers consist of radially arranged coarse, somewhat elongated crystals of clear calcite. Although these layers have obviously been recrystallized and retain no algal structure, they are arcuate and resemble feltlike colonies of certain filamentous algae. Such layers may be recrystallized deposits of calcium carbonate precipitated rapidly upon the algal colonies-for example, by rapid loss of $\mathrm{CO}_{2}$ from the surrounding water. But they are considerably different from the fibrous incrustations of acicular crystals described on pages 217-218 and also different from the concentric layers of oolites and similar thin incrustations upon ostracode shells and detrital grains. They are much less uniform, most of them vary rapidly in thickness from place to place, and their upper surfaces are very irregular and serrate, not smooth like the layers in agate structure. Furthermore, their crystals are not acicular but blunt, and in many layers the individual crystals are not strictly radial, but instead groups of them are canted in various directions. For such deposits Reis ${ }^{31}$ proposed an explanation which to the writer seems plausible-namely, that for some reason the algae died off, and ammonia from their decay precipitated calcium carbonate in the interspaces of the spongy mass and at the same time coarsened the

${ }^{31}$ Reis, O. M., Kalkalgen und Seesinterkalk aus dem rheinpfalzischen Tertiär: Geognostische Jahresh., vol. 36, p. 125, 1923. 
crystal grain so that the original spongy structure was obscured.

The nucleus of this specimen was probably a hard mud lump formed close to the place where it was found, for its reentrants and salients are all smoothly rounded, and as the cardinal salients are no more blunt and rounded than small and protected ones it presumably had not been rolled much before algae became attached to it. During the first stage of growth the nucleus rested upon the base $a-b$, Plate $46, A$. Then the nodule was rolled over, and growth occurred on less than half its surface, probably because it rested against other nodules on the sides $c, a, d$, or because it was partly buried. The third zone of growth apparently formed after the nodule had been again rolled over so that it then rested on some part in front or behind the plane of the polished face.

Because these nodules or algal cobbles occur in massive sandy gray-green clay that is transitional between the Tipton tongue of the Green River formation and the Cathedral Bluffs tongue of the Wasatch formation and may be either fluviatile or lacustrine and because they contain so much fine sand and have obviously been rolled, it seems clear that they were formed in shallow, somewhat active water, perhaps near the mouth of a stream that fed the lake. Although smaller they are comparable to the layers of stream concretions described by Roddy. ${ }^{32}$

These nodules were found in the NE. $1 / 4 \mathrm{SE} .1 / 4 \mathrm{sec}$. 15, T, 25 N., R. 102 W., Sweetwater County, Wyo.

\section{ALGAL PEBBLES}

Algre of the Green River formation built not only extensive reefs and isolated heads and nodules but also rounded pebbles that range from 0.75 millimeter to about 5 centimeters in diameter. Those that are more nearly spherical closely resemble large oolite or pisolite grains; the others resemble ordinary subangular pebbles that have been incrusted with lime. (See pl. 46, B.) Both types and all gradations between them may occur in the same deposit. Furthermore, algal pebbles are almost invariably associated with true oolite grains, algae reefs or their broken fragments, and great quantities of small limy ostracode shells.

Nearly all algal pebbles of the Green River formation are smooth, and although some show a marked tendency to exfoliate thin concentric shells that resemble egg shells, others are more homogeneous and are weakly pustulose.

Under the microscope the algal pebbles show structure wholly analogous to that of the larger reefs and are clearly distinguishable from the inorganic oolites with which they occur. Most of them consist of a spongy aggregate of fine calcite grains that shows no fossil algae, but on the other hand some consist chiefly

sy Roddy, H. J., Concretions in streams formed by the agency of blue-green algae and related plants: Am. Philos. Soc. Proc., vol. 54, pp. 246-248, 257-258, 1915. $100874^{\circ}-29-15$ of layers of Chlorellopsis coloniata. (See pl.47.) Others consist of uniformly microgranular calcite which gives no clue to their origin. These can be distinguished by their shape alone. Although some algal pebbles appear to have no nucleus, most of them are built around small subangular bits of limestone which were probably firm mud when the algae began incrusting them; a few contain ostracode shells or inorganic oolite grains as nuclei.

These fossil algal pebbles are closely similar to algal pebbles now being formed in some lime-rich freshwater lakes of temperate North America. Those collected by the writer in 1925 from the shore near Squaw Island, at the north end of Canandaigua Lake, N. Y., range from 0.5 to about 2 centimeters in diameter, and although they vary greatly in shape, discoid pebbles are most plentiful. The outer crust of each pebble is hard and fairly smooth, but the interior is soft and exceedingly porous because it consists of minute irregular chalky granules held in a close mesh of dead algal filaments that have a vague radial arrangement. If the pores of these pebbles were filled with secondary calcite they would be strikingly like many of those from the Green River formation. Pollock ${ }^{33}$ described the formation of similar algal pebbles in the shallow margins of Ore Lake, Mich.

Presumably the fossil pebbles were formed under similar conditions and in much the same way as the recent pebbles which they so much resemble. However, locally calcium carbonate seems to have been precipitated upon the pebbles without the aid of algae, for in some beds not only the pebbles but also groups of them and ostracode shells and small mud lumps are rather uniformly coated with one or more layers of calcite, which has a distinct fibrous structure with the greatly elongated crystals oriented radially. The writer regards deposits of this lind as resulting from a rapid incrustation due to physico-chemical causes identical with those that produce oolites.

Beds of algal pebbles occur at many places in both the Green River Basin of Wyoming and the Uinta Basin of Utah and Colorado, but the specimens studied came from two localities-one at the base of the Tipton tongue of the Green River formation in the SW. $1 / 4$ NE. $1 / 4$ sec. 27, T. 25 N., R. 103 W., Sweetwater County, Wyo., and the other about 161 meters (530 feet) above the base of the Green River formation in sec. 13 , T. 5 S., R. 102 W., Colo.

\section{POSSIBLE ANNUAL LAMINATION OF ALGAL DEPOSITS}

Roddy ${ }^{34}$ and Schmilde ${ }^{35}$ attribute the lamination of certain fresh-water algal deposits to an annual peri-

${ }^{33}$ Pollock, J. B., Michigan Acad. Sci. Twenticth Ann. Rept., p. 249, 1918.

34 Roddy, H. J., Concretions in streams formed by the agency of blue-green algae and related plants: Am. Philos. Soc. Proc., vol. 54, pp. 253-254, 1915.

3s Schmilde, W., Postglaziale Ablagerungen im nordwestlichen Bodenseegebiet: Neues Jahrb., vol. 11, pp. 114-115, 1910. 
odicity in the growth of the plants, but each author gives a different cause for the periodicity. Roddy in describing algal deposits in a Pennsylvania stream says:

That periodic accretion alternates with a period of quiescence is shown plainly by the concentric laminations of nearly uniform thickness. The open porous nature of each lamina within and the more solid character without, like the concentric arrangement, is due without doubt to the seasonal conditions of the region. Since algae are essentially thermophilic plants, each winter destroys many of them and stops the growth of most of the rest, and thus at beginning of the plant year (spring) few and widely scattered algae at first produce slow and scattered accretion of the limy matter; later the plants become more abundant and by summer they are crowded over the surface of each mass. This distribution of the algae seasonally would naturally have its effect upon the structure and arrangement of the limy matter, giving a decided though rough coralline appearance to the inside portion and a more compact texture to the outer part. The theory just given has been confirmed by a study of the distribution of the algae on the concretionary bodies through the seasons.

Schmilde, on the other hand, described the lamination of small algal pebbles which are being formed in shallow bays of Unter See, Germany, below the outlet of the Lake of Constance. Each winter the water level is lowered, so that the deposits, unlike those described by Roddy, are left dry for several months, and at that time, he says,

the growth of the algae is interrupted or at any rate greatly restricted, while the life processes go on and therefore also the segregation of lime; thus it forms a hard, thin limy crust. In summer and spring, on the contrary, the plants grow up quickly; the precipitated lime therefore accumulates more loosely consolidated and so forms the more porous layers. It seems very much to me, therefore, that the zonal structure of the incrustation is correlated with the periodic growth in dry and wet habitats; it would be scarcely understandable otherwise that an assemblage of algae should be able to show a zonal growth.

The average annual deposit; which consists of a thin dense layer and a soft porous one, ranges in thickness from 1 to 2 millimeters. In the deposits described by Roddy ${ }^{36}$ the annual deposit consists also of a dense and a porous layer, but these together range in thickness from 3 to 6 millimeters.

Not all fresh-water algal deposits, however, are laminated. Those in Green Lake, N. Y., studied by the writer are not, despite the cold winters of that region. Also some reefs in the Green River formation are not laminated. The presence or absence of distinct lamination in algal deposits might be accounted for by a hypothesis that differs slightly from either Roddy's or Schmild's-namely, that the thin dense layer is due to recrystallization in a thin zone at the surface of the deposit. If the rate of recrystallization is constant throughout the year or perhaps even lessened during the winter, then it will, nevertheless, have a considerably longer time to operate at one horizon of the deposit during the winter when the algae are

${ }^{86}$ Roddy, H. J., op. cit., pp. 249-250. either dead or relatively inactive and consequently not adding to the deposit. But several factors might operate to counteract the recrystallization during the winter. If the rate of recrystallization were slow and the algae mildly active, the deposit might grow so fast that the effects of recrystallization would be distributed through a thicker zone, as in the summer deposit, and so would not be discernible. A more probable factor, however, might be actual solution of the calcium carbonate at the surface of the deposit due to the greatly increased concentration of the carbon dioxide dissolved in the lake water. Chambers ${ }^{37}$ and Powell ${ }^{38}$ have observed that the carbon dioxide and bicarbonate content of pond and reservoir waters increases noticeably during the winter, owing largely to the lessened activity of submerged aquatic plants but also to the greater solubility of the carbon dioxide in cooler water. This perhaps accounts for the absence of lamination in the reefs from Green Lake, $N$. Y., although, so far as the writer is aware, no analyses of the water in Green Lake have been made to determine the relative quantities of dissolved carbon dioxide in summer and winter. Thin dense surface zones formed by recrystallization were found only in those parts of the algal deposits in Green Lake that are buried in limy mud and therefore necessarily barren of algae.

Many but not als the algae reefs from the Green River formation are distinctly laminated. Those whose lamination seems most likely to be annual are the pitted reefs built by Chlorellopsis coloniata Reis. Many layers consist of numerous individual algal colonies that rise uninterrupted from a common substratum to the top of the layer, which is marked by a thin, dense, and generally darker-brown layer. These algal layers vary greatly in thickness, even within the same reef. Of the 56 layers measured the thinnest is 1 millimeter, the thickest about 15 millimeters, and the average 6 millimeters. Although the writer realizes fully that these layers may not be annual and might possibly even represent many years, probably none of them represent less than one year. Consequently any estimates of time based on them will err in being too short.

According to this average rate of accumulation the large pitted reef shown in Plate 40, $A$, which is locally as much as 2.1 meters ( 7 feet) thick, must have required at least 355 years to form. Sernander ${ }^{39}$ found at Benestad, in southern Sweden, varved postglacial algal tufas whose rate of growth is comparable to those of the Green River formation. The summer

${ }^{37}$ Chambers, C. O., The relation of algae to dissolved oxygen and carbon dioxide, with special reference to carbonates: Missouri Bot. Garden Ann. Rept., vol. 23, pp. 187-192, 1912.

39 Powell, S. T., The effect of algae on bicarbonates in shallow reservoirs: Am. Waterworks Assoc. Jour., vol. 2. pp. 703-708, 1915.

${ }^{30}$ Sernander, Rutger, Exkursions fürher für Skáne: Vierte Internat. Pflanzengeog. Exkursion durch Skandnavien, 1925; cited by Antevs, Ernst, Varved sediments, in Twenhofel, W. H., and others, Researches in sedimentation in 1925-26, p. 83, National Research Council, 1926. 
layers are foose, and the autumn layers, which contain leaf inmpressions, are thin and hard. A bed of that tufa 1.81. metters thick had 420 varves, which averaged 4 millijmetiers in thickness.

The pittited Chlorellopsis reefs are more coarsely laminated and thence presumably grew more rapidly than the other maefs of the Green River formation, but a dinect comparison of the rates can not be made because the time value of the laminae in the other reefs is far too ameertain.

\section{OOLTES}

In an carlier paper ${ }^{40}$ the writer stated his belief that the oolities so intimately associated with the algae reefs in northern Sweetwater County, Wyo., were formed by algae or bacteria. In this more critical study of several specimens of oolites from various parts of the Green River formation the writer not only found no reason to postulate a genetic relation between bacteria and the oolites but also was unable to find any conclusive revidence to support the hypothesis that they were formed by algae. On the contrary, it can be clearly demonstrated that the oolites of a few beds are of inorganic origin. One of these beds consists almost wholly of a gently cross-bedded mixture of small oolite grains and fine grains of quartz and feldspar, but it also contains several small flat mud lumps and mud curls. Some of the smaller lumps consist of calcite that is nearly cryptocrystalline. These contain a few oolite grains that do not touch and in general are widely spaced. Clearly they were suspended in the matrix when it was an ooze. (See pl. 48, B.) The oolite grains themselves have no fibrous or radial structure but are exceedingly fine grained and indisguishable from the matrix except for their perfect though rather wide concentric banding and noticeably darker color. They are dark yellowish brown, whereas the matrix is pale brownish gray. Evidently the color is due to iron, because the weathered oolite grains are conted with limonite. Moreover, the iron is clearly concentrated in them with respect to the matrix. Nuclei are rare, but some of the oolite grains contain minute quartz or feldspar grains at their centers.

Apparently these oolites in the dense matrix were formed in a similar manner to that elucidated by Schade. ${ }^{41}$ The original ooze or gel in which the oolite grains formed consisted of colloidal ferric hydroxide with a large admixture of extremely finely divided calcium carbonate. From the facts that the calcite crystals in the oolites and matrix are now only 1 to 2.5 microns in diameter and that some crystal growth has probably occurred since the Eocene it is possible that the calcium carbonate may also have been in a

\footnotetext{
10 Bradley, W: T., Shore phases of the Green River formation in northern Sweetwater County, Wyo.; U. S. Geol. Survey Prof. Paper 140, p. 126, 1926.

" Schade, Heinrich, Zur Entstehung der Harnsteino und ahnlicher konzentrisch geschichteter Stcine organischen und anorganischen Ursprungs: Zeitschr. Chemie u. Industrio der Kolloide, vol. 4, p. 265, 1909.
}

colloidal state, though that would not have been necessary for the formation of oolites. Growth of the calcite crystals was perhaps inhibited by the protective action of the colloidal ferric hydroxide. Moreover, the complete absence of long acicular crystals forming radial structure strengthens this possibility, especially because the calcium carbonate or crystalloid component'was large. The ferric hydroxide must have been coagulated by negative ions such as carbonate or chloride in the solution, and then because the minute coagulated particles are unstable in the presence of larger ones, and apparently also in the presence of any larger foreign particle such as a quartz or feldspar grain, they coalesced into spheres, mechanically enmeshing a considerable quantity of the suspended calcium carbonate. By that process the oolite grains. grew. Apparently their growth was limited by the supply of ferric hydroxide, as they seem to have abstracted the greater part of it from the matrix. Their concentric lamination, as Schade's experiments ${ }^{42}$ indicate, is a characteristic property of coagulated colloids that contain admixtures of foreign material and depends upon slight changes in the proportions of the constituents, upon concentration of the salt solution, and consequently also upon the rate of coagulation of the colloidal component and the viscosity of the fluid or gel.

Now, because all the isolated oolite grains, which made up a considerable part of the whole bed, are precisely identical with those in the small pieces of dense matrix it seems probable that they were also formed in the same way and, moreover, in the same medium or matrix, but that the matrix was washed away from them when the bottom deposits at that place were reworked by waves or currents. Only those parts of the matrix that were partly solidified, perhaps by incipient recrystallization after the abstraction of the ferric hydroxide to form the oolites, or perhaps only bound by some of the residual colloidal matter, were able to withstand the disturbance and thus form the small lumps containing the oolite grains still suspended as they were formed.

Both Bucher ${ }^{43}$ and Twenhofel ${ }^{44}$ state that for oolites to be formed through the change of at least one component from a colloidal to a solid state it is necessary that the oolite grains should grow suspended in an ooze or a jelly-like medium. Obviously some and perhaps most oolites are formed while suspended in gel or ooze, but is that a necessary factor? Schade's experiments ${ }^{45}$ seem to indicate that it is not, for he states that only an imperceptible quantity of the colloidal component relative to the crystalloid pre-

\footnotetext{
12 Idem, pp. 262-264.

43 Bucher, W. H.; On oolites and spherulites: Jour. Geology, vol. 26, p. 603, 1918.

4 Twenhofel, W. H., Treatise on sedimentation, p. 543, 1926

15 Schade, Heinrich, Zur Entstehung der Harnsteine und ähnlicher konzentrisch geschichteter Steine organischen und anorganischen Ursprungs: Zeitschr. Chemie u. Industrie der Kolloide, vol. 4, p. 263, 1909.
} 
cipitate is necessary for the successful formation of artificial gallstones. Moreover, those gallstones, which are oolites, are formed in a mobile liquid and are not suspended in a gel. Furthermore, as natural gallstones are formed their liquid medium is almost continuously in motion. So also the oolites that were formed in the hot-water coil of a furnace as described by Twenhofel ${ }^{46}$ must have been alternately at rest and in motion in a liquid far too fluid to hold them in suspension.

Furthermore, the vegetable pearls formed in the interior of a coconut as mentioned in another paper by Schade ${ }^{47}$ probably rested on the bottom of the coconut and were occasionally moved about. These so-called pearls consist of $\mathrm{CaCO}_{3}$ with a nitrogenous organic substance as the binding colloid. All that appears to be requisite for the formation of the oolites in Schade's experiments ${ }^{48}$ was the coagulation of a very small amount of a colloidal substance with which may be admixed, in almost any proportions, one or more other components. In gallstones the other component is a crystalloid which precipitates out of a salt solution. Now Schade ${ }^{49}$ further points out that the tendency of the minute droplets or globulites of coagulated fibrin to coalesce and form larger droplike particles with a netlike structure of intersecting needles thickened at their intersections and the subsequent shrinkage of the mass are not peculiar to fibrin but are common to other colloids.

Empirically, therefore, it seems wholly possible that calcareous oolites might be formed in natural environments that were quite as fluid as the media in which natural and artificial gallstones are formed. Lake water might be saturated with calcium carbonate and contain a colloidal component such as ferric hydroxide, silica, algal gelatine, or some of the products of decomposing organic matter so dispersed that it would not increase the viscosity of the solution enough to hold nuclei and small oolite grains suspended. Such conditions where the growing oolites rest one against the next or are only partly suspended in silty mud and are occasionally moved by storms seem to the writer better adapted to the formation of many of the oolites in the Green River formation, especially those larger than 1 millimeter in diameter, for they are unsymmetrical, are of various sizes, and show two or more zones of concentric growth that are eccentric with respect to one another and in some also to the nucleus. (See pl. 48, A.) Moreover, many of them contain layers in which clay and silt are generously admixed with the microcrystalline calcite.

\footnotetext{
${ }^{16}$ Twenhofel, W. H., Treatise on sedimentation, p. 540, 1926

${ }^{7}$ Schade, Heinrich, Über Konkrementbildungen beim Vorgang der tropfigen Entmischung von Emulsions-kolloiden: Kolloidchemische Beihefte, Band 1, pp. 375-390, 1910.

18 Schade, Heinrich, Zur Entstchung der Harnsteine und ähnlicher konzentrisch geschichteter Steine organischen und anorganischen Ursprungs: Zeitschr. Chemie u. Industrie der Kolloide, vol. 4, p. 263, 1909.

6 Idem, p. 178
}

Conditions in Pyramid Lake; Nev., perhaps approaching these have been described by Jones.50 When the lake is clear and quiet the oolites, which are not suspended but rest against each other on the bottom, grow by the formation of minute aragonite needles that are radially oriented; but when the bottom is stirred up by storms the silt that is thrown into suspension is admixed with the aragonite, and granular stony layers. that are concentric with those layers having radial fibrous structure are formed. In Pyramid Lake, however, the calcium carbonate is being precipitated from warm spring water, and so the conditions are somewhat different from those that must have prevailed in the ancient Green River lakes, where the beds of oolite are many square miles in area and an origin by warm springs is almost surely precluded. Yet probably the means by which the components are precipitated has little general effect upon the growth of the oolite grains, provided the material is in the proper state. Thus the precipitation of calcium carbonate from lake water by a change in temperature or by the gradual abstraction of carbon dioxide from the bicarbonates in solution by the growth of submerged aquatic plants, as described by Hassack, ${ }^{51}$ Chambers, ${ }^{52}$ and Powell, ${ }^{53}$ together with the simultaneous coagulation of even a very small amount of a suitable binding colloid, might conceivably produce oolites over large areas of the lake bottom, even though the bottom was sandy or silty and the growing oolite grains were not suspended. Soft ooze bottoms would of course provide a medium in which oolite grains, at least while small, would be more or less completely suspended. Such an ooze might not necessarily contribute to the growth of the oolite grains except in so far as it was mechanically enmeshed.

\section{SUMMARY}

Certain but not all chlorophyll-bearing algae precipitate calcium carbonate from natural waters by their photosynthesis, a process by which they abstract not only the carbon dioxide that is dissolved in water but also that held in solution as bicarbonates. This process has for a long time been clearly established by laboratory experimentation and observation of algae in natural habitats. As this process depends directly upon sunlight it follows that the algae reefs in the Green River formation must have been produced in shallow water that was relatively clear, at least for the

30 Jones, J. C., Quaternary climates; Geologic history of Lake Lahontan: Carnegie Inst. Washington Pub. 352, pp. 14-18, 1925.

s1 Hassack, Carl, Über das Verbăltnis von Pflanzen zu Bicarbonaten und über Kalkincrustation: Untersuchungen aus dem Bot. Inst. Tübingen, vol. 2, pp. $467-473,1888$.

52 Chambers, C. O., The relation of algae to dissolved oxygen and carbon dioxide with special reference to carbonates: Missouri Bot. Garden Ann. Rept., vol. 23, pp. 178-204, 1912.

53 Powell, S. T., The effect of algae on bicarbonates in shallow reservoirs: Am. Waterworks Assoc. Jour., vol. 2, pp. 703-708, 1915. 
greater part of the time. These two factors, however, are plainly interdependent, the depth at which the algae reefs could be formed varying directly as the clarity, or, stated better, inversely as the turbidity, which is the principal factor limiting light penetration in fresh water. ${ }^{54}$ The depth may have been as much as 4.5 meters (15 feet), or perhaps even more, but probably most of the reefs and certainly some of them were formed in water less than 1.8 meters (6 feet) deep. One reef at least was formed in very shallow water, for it contains the molds of emergent plant stems in the position in which they grew.

In order that the limestone precipitated by the algae could persist, as Johnston and Williamson ${ }^{55}$ have pointed out for limestone in general, the water surrounding them must have been saturated with respect to the normal carbonate of calcium. From this it follows that lime was continually being brought into the lake and that the water circulated, even though perhaps slowly, and thus replenished the lime precipitated by the algae. Rather vigorous circulation of the water around many of the reefs and beds of algal nodules and pebbles is, however, revealed by fragments of algal deposits, limy mud lumps, and transported sand and oolite grains either within the reefs or very intimately associated with them. Indeed pebbles as much as 1 centimeter in diameter are associated with one reef.

Algae reefs are most plentiful in shore phases of the Green River formation, where they are irregularly distributed through the entire thickness of the formation, but elsewhere they are confined almost wholly to the basal member, whose lithology is similar to that of the shore phases. At a few localities remote from shore phases, where those parts of the formation between the basal member and the lowest oil-shale zone and between the uppermost oil-shale zone and the top of the formation consist of hard limy or silty shale, there are a few thin algae reefs.

The reefs are nowhere closely associated with oil shale even of very low grade. Their absence from those parts of the formation that consist predominantly of oil shale is clearly due to the fact that the conditions necessary to the formation of oil shale are distinctly unfavorable to the formation of algae reefs. Where oil shale was formed stagnation of the water and putrefaction of great quantities of organic matter effectively inhibited the growth of algae, which were the most active reef builders. Furthermore, in those parts of the lake where decaying organic ooze was abundant the ammonia generated by the decay quickly precipitated the calcium carbonate, which in turn was buried in the ooze or formed thin layers upon it.

st Forel. F. A., Lo Leman, vol. 2, pp. 426-427, 1895

ss Johnston, John, and Williamson, E. D., The rôle of inorganic agencies in the deposition of calcium carbonate: Jour. Geology, vol. 24, p. 735, 1916.
The scarcity of algae reefs in the uppermost member of the formation, even in deposits that were clearly laid down in shallow water, may be ascribed to one or more of three causes-(1) the increased concentration of sulphates in the lake, which at one stage became so great that a large quantity of glauberite crystallized out in the mud; (2) a lessened quantity of lime in solution available for the formation of algae reefs, either because lime was less soluble in the more saline lake water or because the supply brought to the lake was diminished; (3) periodic evaporation of the lake during the normal growing season of the algae.

From the distribution of the algae reefs, their bedlike shape, and their evident origin in very shallow water, the writer concludes that the shore phases of the Green River formation, some of which are as much as 40 kilometers (25 miles) wide, and also much of the whole basal member were deposited in water not more than 15 feet deep. The floors of the two great Eocene lakes, even from the beginning, were very smooth and had only gentle basinward slopes, for the original surface that each lake flooded was a nearly level plain of fluviatile aggradation, marking the top of the Wasatch formation. The wide lateral distribution of suncracked bedding planes and of mud curls at many horizons in the lacustrine deposits, moreover, indicates that during the greater part of their existence the lakes had nearly level bottoms.

The basal member of the Green River formation contains more algae reefs in the vicinity of the Douglas Creek anticline than on either side of it. From this the writer concludes that the lake was shallower there, although it is in the central part of the basin.

Algae reefs in parts of the formation above the basal member and remote from the shore phases represent a reversion of the ecologic conditions to those which prevailed at earlier stages of the lakes. Reefs in the upper parts of shore phases that are contemporaneous with the saline stages of the lakes were very probably formed close to the mouths of streams or perhaps in small, somewhat isolated basins fed by streams or fresh springs.

The abrupt change in lithology between the basal member and the upper part and the absence or scarcity of algae reefs from the upper part indicate a decided change in the ecology of the lakes, but a discussion of that subject is not germane to this report.

According to the writer's interpretation of the origin of calcareous oolites and of fresh-water algae reefs oolites may be intimately associated with algae reefs because the conditions favorable to the formation of oolites are in general also favorable to the growth of algal limestone deposits, though the converse is by no means true; or they may be intimately associated because the oolite grains were transported to the growing reef in the same way that clastic grains are carried to and inclosed in algae reefs. 